\title{
SISTEMA DE INFORMAÇÃO GEOGRÁFICA PARA APOIO A DECISÃO AO COMBATE A INCÊNDIO
}

Dissertação apresentada Escola de Engenharia de São Carlos, da Universidade de São Paulo como parte dos requisitos para obtenção do título de Mestre em Engenharia de Produção.

Orientador: Prof. Dr. Edson Walmir Cazarini

São Carlos 


\section{Dedicatória}

Dedico este trabalho aos meus pais, Jeú e Lenira, ao meu irmão Juliano e à minha noiva Juliana, que sempre estiveram presentes na minha trajetória, acompanhando e incentivando meu trabalho. 


\section{Agradecimentos}

A DEUS por me dar saúde e vida.

Aos professores da EESC, Edmundo Escrivão Filho, Daniel Capaldo Amaral e Fabio Müller Guerrini que contribuíram para minha formação.

Ao professor Edson Walmir Cazarini pelo apoio.

À minha família pelo incentivo.

À minha noiva Juliana de Andrade pelo apoio e companheirismo.

Ao professor Sérgio Luiz Antonello do CEAPLA da Unesp de Rio Claro.

Ao Corpo de Bombeiros de Rio Claro pela oportunidade de realizar este trabalho.

Aos funcionários da EESC que me sempre me atenderam em todas as minhas necessidades. 
Eis que chega a hora, e já se aproxima, em que vós sereis dispersos a cada um para sua parte, e me deixareis só; mas não estou só, porque o Pai está comigo.

Tenho vos dito isto, para que em mim tenhais paz; no mundo tereis aflições, mas tende bom ânimo, eu venci o mundo. João 16, 32:33. 


\section{Resumo}

GONÇALVES, Pablo Rodrigo. (2005). Sistema de informação geográfica para apoio a decisão ao combate a incêndio. 154p. Dissertação (Mestrado) - Escola de Engenharia de São Carlos, Universidade de São Paulo, São Carlos.

Os Sistemas de Informação Geográfica (SIG) são sistemas que possuem uma grande variedade de aplicações e podem ser utilizados para tomada de decisões. O presente trabalho apresenta um SIG para localização de pontos de abastecimento de água dentro de um município. Através deste SIG o corpo de bombeiros tem melhores condições de determinar quais os locais ideais para abastecimento de uma viatura durante o atendimento a uma ocorrência de incêndio. Uma pesquisa-ação foi realizada para acompanhar a implantação deste SIG dentro de um posto do corpo de bombeiros. A partir do uso desta ferramenta os bombeiros podem tomar decisões mais rápidas e precisas, melhorando o desempenho da organização.

Palavras-chave: sistemas de informação geográfica, sistemas de apoio a decisão, segurança publica, pesquisa-ação 


\section{Abstract}

GONÇALVES, Pablo Rodrigo. (2005). Sistema de informação geográfica para apoio a decisão ao combate a incêndio. 154p. M.Sc. Dissertation - Escola de Engenharia de São Carlos, Universidade de São Paulo, São Carlos.

The Geographic Information System (GIS) are systems that possess a great variety of applications and can be used for taking of decisions. The present work inside presents a GIS for localization of points of water supplying of a city. Through this GIS the body of firemen it has better conditions to determine which the ideal places for supplying of a vehicle during the attendance to a fire incident. An action research was realized to follow the implantation of this GIS in the fire department.

From the use of this tool the firemen can take faster and necessary decisions, improving the performance of the organization.

Keywords: Geographic Information System, Decision Support System, Public Security, Action Research 


\section{Lista de Figuras}

Figura 1 - Exemplo de um processo de tomada de decisão. ..........................45

Figura 2 - Modelo de processo de tomada de decisão. ..............................47

Figura 3 - Diferentes representações matriciais para uma mapa.....................56

Figura 4 - Distribuição de casos de mortalidade em Porto Alegre. ...................59

Figura 5 - Tela Inicial do Sistema............................................................ 106

Figura 6 - Tela de Cadastro de Hidrantes .................................................... 107

Figura 7 - tela de Cadastro dos Registros de Recalque ...............................107

Figura 8 - Representação de um Hidrante no Mapa ..................................... 108

Figura 9 - Representação dos Registros de Recalque no Mapa...................... 109 


\section{Lista de Quadros}

Quadro 1 - Fases do incêndio................................................................ 30

Quadro 2 - Características das linhas de ataque a incêndio.............................36

Quadro 3 - Classificação dos veículos do serviço de bombeiros.......................37

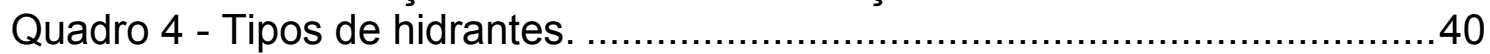

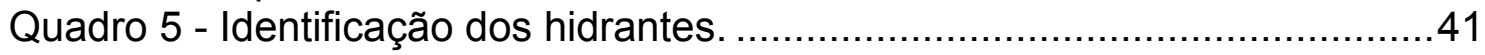

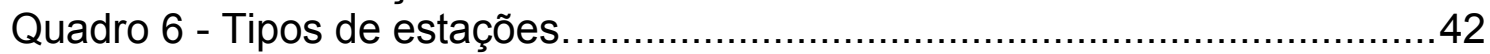

Quadro 7 - Classificação das cartas cartográficas ........................................52

Quadro 8 - Usos e benefícios de SIGs no nível operacional ...........................63

Quadro 9 - Usos e benefícios de SIGs no nível gerencial .............................64

Quadro 10 - Usos e benefícios de SIGs no nível estratégico ...........................65

Quadro 11 - Exemplo de uso do SIG em benefício direto da sociedade ..........65

Quadro 12 - Modelo de implementação de um SIG......................................75

Quadro 13 - Estrutura da tabela de hidrantes ..........................................105

Quadro 14 - Estrutura da tabela de registros de recalque ...........................106 


\section{Sumário}

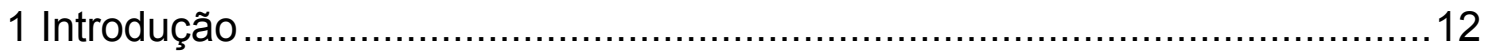

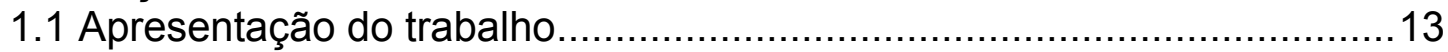

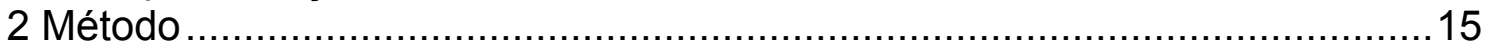

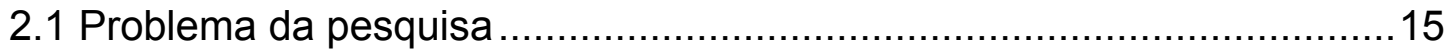

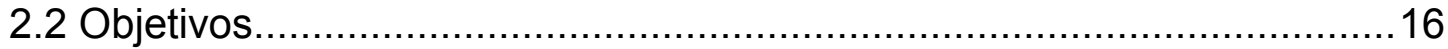

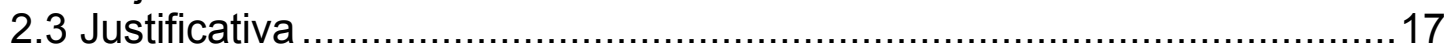

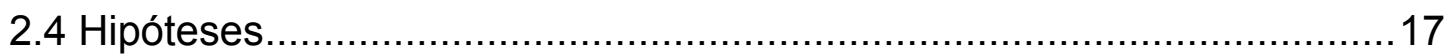

2.5 Método de pesquisa e delineamento ................................................. 17

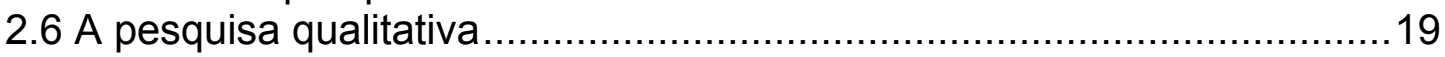

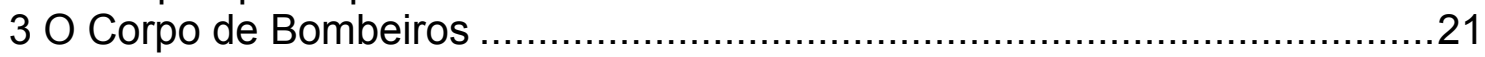

3.1 Histórico do Corpo de Bombeiros do Estado de São Paulo ....................23

$3.2 \mathrm{O}$ fogo como um problema socioeconômico.........................................2

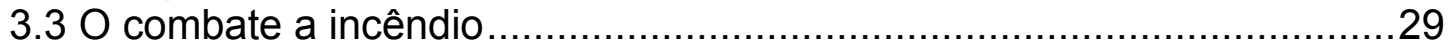

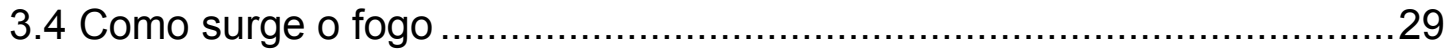

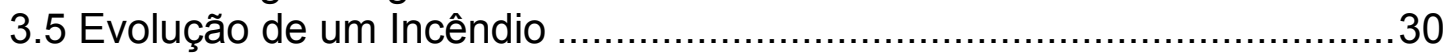

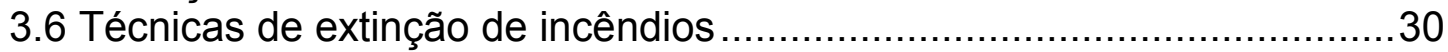

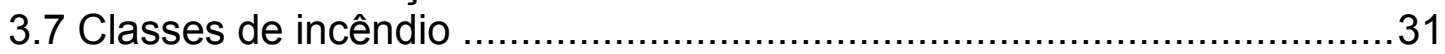

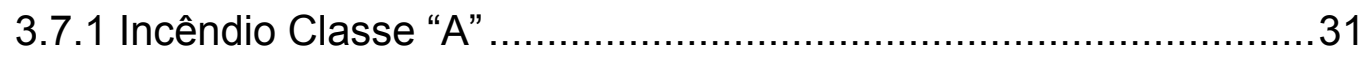

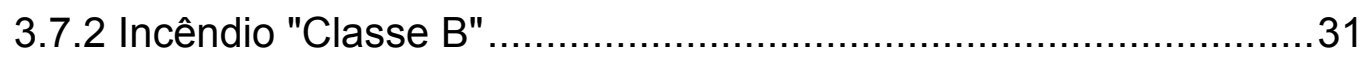

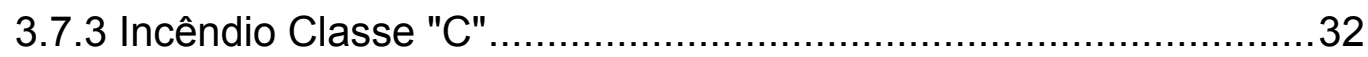

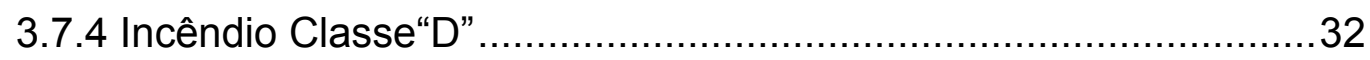

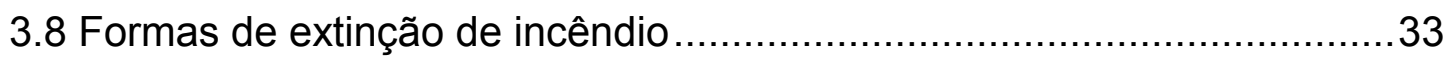

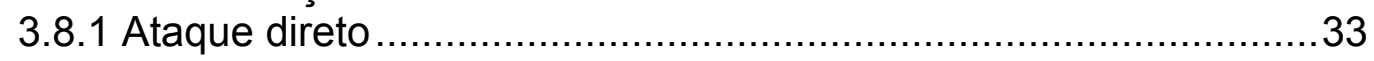

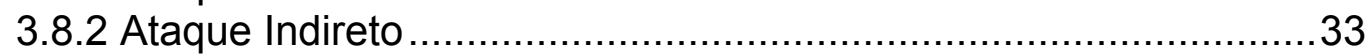

3.9 Elementos decisivos para o combate ao incêndio....................................36

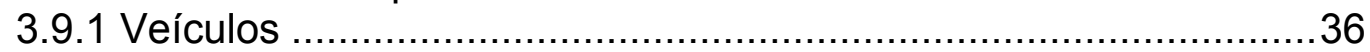

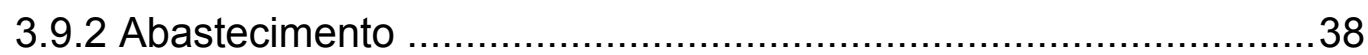

3.9.4 Importância dos pontos de abastecimento ........................................39

3.9.3 Comunicação ................................................................... 41

3.9.5 Órgãos de Comunicação........................................................42

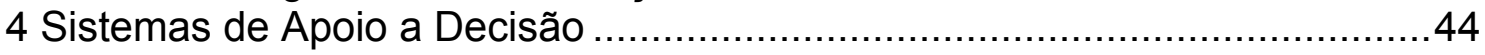

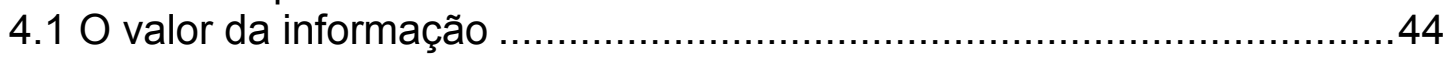

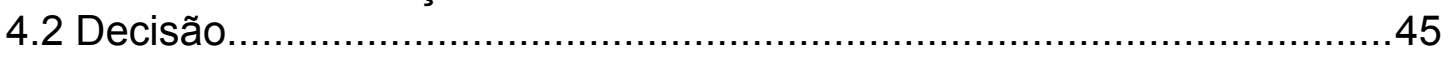

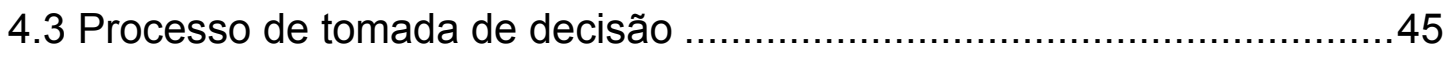

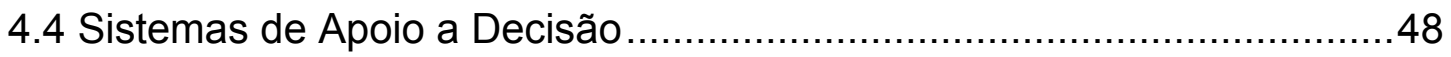

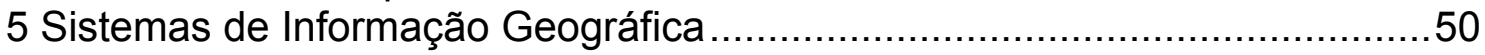

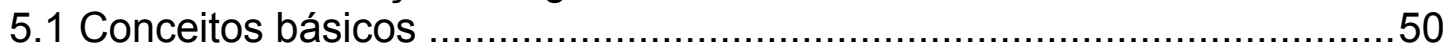

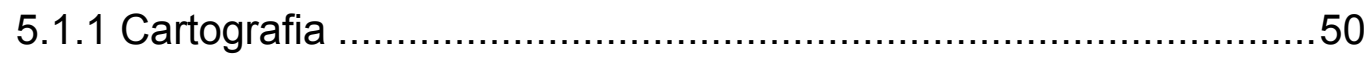

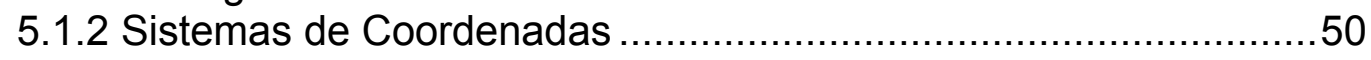

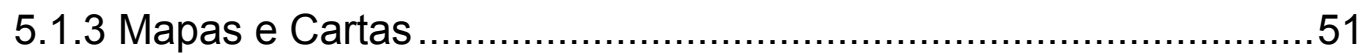

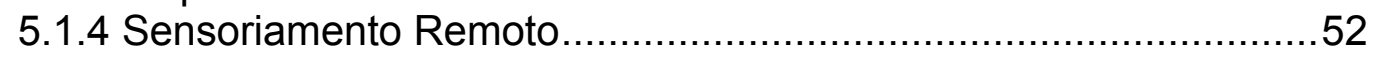

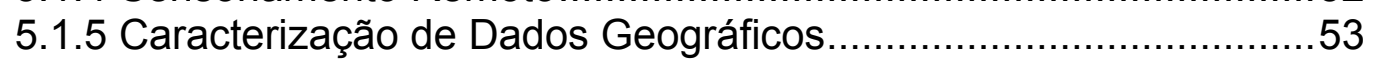

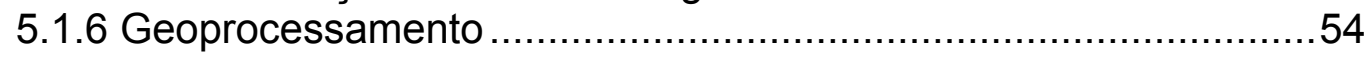

5.1.7 Tipos de dados em geoprocessamento ....................................54

5.1.8 Representação Vetorial e Matricial............................................56

5.2 Sistemas de Informação Geográfica (SIG) ..........................................57

5.3 Diferenças entre o termo espacial e geográfico .................................58

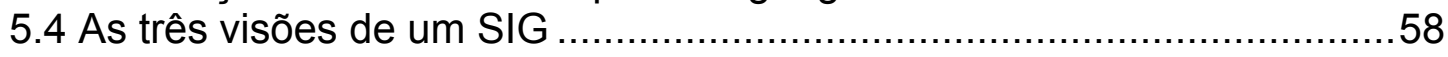


5.5 Os elementos de um Sistema de Informação Geográfica .....................60

5.6 Utilizando o SIG.......................................................................... 62

5.6.1 Uso de SIGs no nível operacional .........................................62

5.6 .2 Uso de SIGs no nível gerencial ..........................................63

5.6.3 Uso de SIGs no nível estratégico ...........................................64

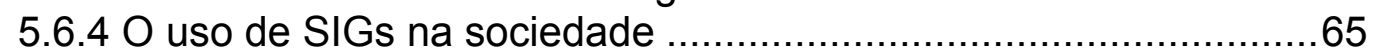

6 Metodologias de implantação de um SIG ...........................................66

6.1 Modelo de implantação segundo Huxhold (1995) .............................6 67

6.1.1 Plano de implementação ....................................................67

6.1.2 Desenvolvendo uma visão conceitual .....................................69

6.1.3 Preparando um plano de implementação..................................70

6.1.4 Plano de partida .............................................................. 70

6.1.5 Projeto geral ..................................................................... 71

6.2.1 Estágio 1: Análise de requisitos .......................................... 75

6.2.2 Estágio 2: Especificação dos requisitos. .................................79

6.2.3 Estágio 3: Avaliação de alternativas....................................... 80

6.2.4 Estágio 4: Implantação do sistema....................................... 81

6.3 Aspectos importantes para o sucesso da implantação de um SIG .........82

6.4 Problemas encontrados na implantação e gerenciamento de um SIG....84

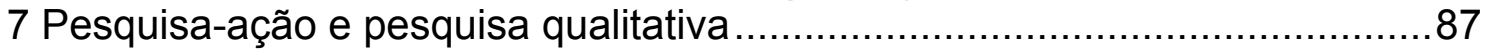

7.1 Principais características da pesquisa-ação ..................................... 88

7.2 Quando a pesquisa-ação é apropriada ............................................90

7.3 Implementando a pesquisa-ação...................................................90

7.4 Diferença entre pesquisa-ação e consultoria......................................93

7.5 A pesquisa-ação nas organizações ................................................99

7.6 O campo de estudo ............................................................... 94

7.7 A documentação de dados da pesquisa ......................................... 95

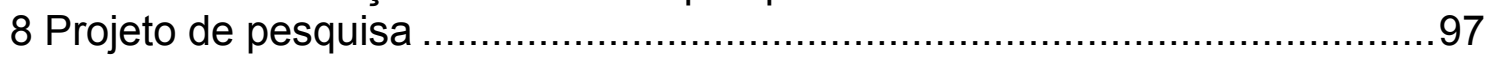

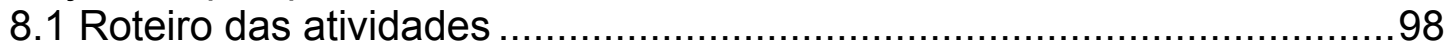

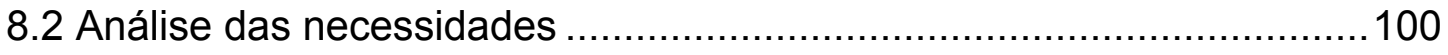

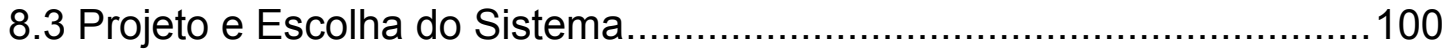

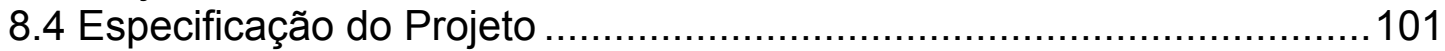

8.4.1 Mapa do município ............................................................ 101

8.4.2 Visualização de dados geográficos ....................................... 103

8.4.3 A seleção de hidrantes....................................................... 104

8.4.4 A inclusão dos Registros de Recalque ................................... 104

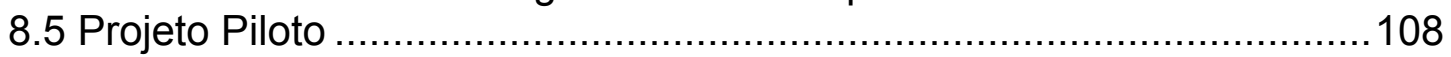

8.6 Consultas ao mapa................................................................ 110

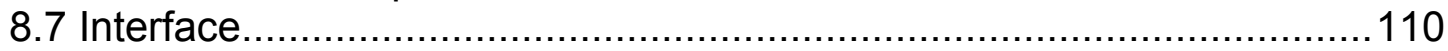

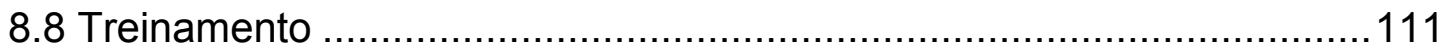

8.8.1 Etapa A - Treinamento Básico .........................................112

8.8.2 Etapa B - Treinamento de consulta a dados ..........................113

8.8.3 Etapa C - Terceira etapa do treinamento ................................113

8.8.4 Etapa D - Quarta etapa do treinamento................................113

8.9 Migração do projeto piloto para o sistema final ...............................114

8.10 Implantação do sistema final .................................................. 114

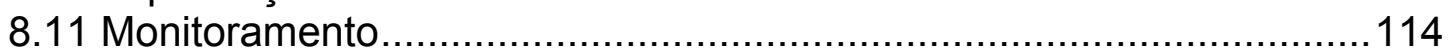

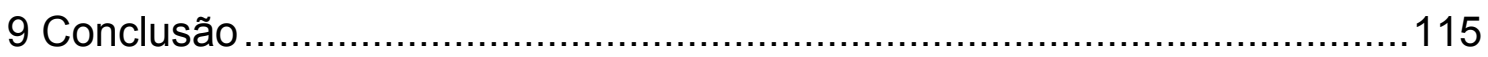

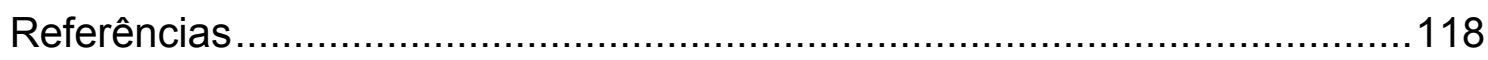

Apêndice A - Cronograma das aulas de Autocad Map ............................... 123 
Apêndice B - Cronograma das aulas de Autocad Map 143 Apêndice $\mathrm{C}$ - Diário de Pesquisa 


\section{Introdução}

Um dos problemas que afetam as cidades brasileiras, principalmente as médias e grandes cidades é a dificuldade que os órgãos públicos têm de promover a segurança pública. Esta introdução tem o objetivo de caracterizar um desses problemas que dificultam a preservação do meio ambiente, do patrimônio e da vida.

O corpo de bombeiros é um órgão do Estado responsável pela segurança pública e objeto deste trabalho.

A rapidez e precisão na obtenção da informação para este órgão são imprescindíveis, pois qualquer falha ou demora em um atendimento pode resultar em perda de vidas e destruição do patrimônio e meio ambiente.

Um dos problemas enfrentados pelo corpo de bombeiros tem origem na falta de informações sobre localização geográfica de pontos de abastecimento de água dentro do município. Em uma ocorrência de incêndio o bombeiro precisa ter a maior quantidade possível de informações em mãos para poder tomar decisões adequadas sobre onde abastecer a viatura e retornar ao local de ocorrência da maneira mais rápida possível. 


\subsection{Apresentação do trabalho}

Esta dissertação está dividida em nove capítulos, dos quais a Introdução faz parte do capítulo um. O conteúdo de cada capítulo é apresentado a seguir:

O segundo capítulo aborda a metodologia adotada no trabalho. São relatados os objetivos, as justificativas e hipótese da pesquisa. Além de um breve comentário sobre o método de pesquisa e delineamento.

O terceiro capítulo apresenta o trabalho do Corpo de Bombeiros. Descreve suas atividades, estatísticas de atendimento e equipamentos utilizados. Este capítulo também apresenta as características dos sistemas de hidrantes e informações sobre sua localização dentro do perímetro urbano do município de Rio Claro.

O quarto capítulo aborda a teoria da decisão e o processo decisório, apresentando suas características.

O quinto capítulo trata dos Sistemas de Informação Geográfica, dando uma visão geral do que são estes sistemas. Inicialmente, faz-se uma breve introdução, descrevendo-se as características fundamentais de um SIG, seus benefícios e suas vantagens.

O sexto capítulo tem o objetivo de apresentar uma revisão bibliográfica a respeito das metodologias consultadas para a implantação do sistema de informação geográfica implantado no posto de bombeiros do município de Rio Claro.

O sétimo capítulo trata da pesquisa-ação e da pesquisa qualitativa, mostrando quais são as principais características deste tipo de pesquisa. 
O oitavo capítulo apresenta o projeto de pesquisa e a implementação de um sistema de informação geográfica no Corpo de Bombeiros de Rio Claro - SP, bem como a metodologia utilizada, descrevendo quais as dificuldades de desenvolvimento encontradas bem como os benefícios que este sistema proporcionou.

O nono capítulo apresenta as conclusões do trabalho. 


\section{Método}

Este capítulo apresenta o método empregado. Inicia com a apresentação do problema da pesquisa. Em seguida são apresentadas as hipóteses assumidas e os objetivos a serem atingidos. Ao final são apresentados os aspectos referentes à escolha do método.

\subsection{Problema da pesquisa}

Este trabalho foi desenvolvido sobre um problema prático de pesquisa, identificado durante visitas feitas ao posto de bombeiros do município de Rio Claro, SP.

Durante essas visitas, vários problemas foram identificados no que diz respeito ao acesso à informação. Entre as origens deste problema destacam-se a falta de software adequado para processamento das informações e falta de conhecimento na área de informática por parte do setor administrativo do posto de bombeiros.

Com relação à falta de informação, destacam-se aquelas que são essenciais durante $\mathrm{o}$ atendimento de uma ocorrência.

Em geral o corpo de bombeiros não possui um sistema de informação para gerenciar a localização de pontos de abastecimento. Em situações de emergência, no atendimento de uma ocorrência de incêndio, os bombeiros podem ter dificuldade em encontrar um ponto próximo ao local de atendimento para o reabastecimento da viatura, que pode resultar em demora e incerteza na tomada de decisão. Podendo vir a prejudicar toda a operação de eliminação do foco de incêndio. 
Dentre os motivos desta demora destacam-se a falta de conhecimento que o soldado responsável pelo atendimento da ocorrência tem sobre a localização de um endereço dentro da cidade. Em algumas situações ele tem que procurar em mapas ou listas o endereço para poder orientar as viaturas no atendimento da ocorrência e na procura por pontos para reabastecimento.

Para Gil (1999), um problema é "qualquer questão não solvida e que é objeto de discussão, em qualquer domínio do conhecimento". Para o autor, um problema é testável cientificamente quando envolve variáveis que podem ser observadas ou manipuladas.

De acordo com esta definição e panorama acima descrito, apresenta-se o seguinte problema:

Quais aspectos devem ser observados na implantação de um Sistema de Informação Geográfica (SIG) para a localização de pontos de abastecimento de água para que este seja eficiente e dê suporte à decisão?

Entende-se que estes aspectos podem ser observados e manipulados pelo pesquisador a fim de alcançar o objetivo proposto para o trabalho.

\subsection{Objetivos}

Face às considerações apresentadas anteriormente, o presente trabalho tem objetivo principal de:

Identificar os aspectos da implantação de um SIG, servindo como um guia para os postos de bombeiros que desejam informatizar seu sistema de localização de pontos de abastecimento de água.

Este é objetivo central do trabalho. Para atingi-lo foi criado um SIG e sua implantação foi acompanhada dentro do posto de bombeiros da cidade de Rio Claro. Foi realizado um treinamento para o pessoal responsável pela operação do software e relatadas neste trabalho as dificuldades encontradas tanto no desenvolvimento como na implantação. 


\subsection{Justificativa}

Promovendo uma rápida localização dos pontos de abastecimento o bombeiro responsável pelo atendimento tem melhores condições de decidir qual local ideal para o abastecimento da viatura. Levando-se em consideração que esta é uma situação de risco, a tomada de decisão rápida e eficaz torna-se fundamental para a eliminação do foco de incêndio, preservando o patrimônio, o meio ambiente e a vida humana.

\subsection{Hipóteses}

Do problema de pesquisa exposto acima, foram derivadas as seguintes hipóteses:

1. É viável a criação de um SIG para localização de pontos de abastecimento através de um software que pode ser utilizado pelo posto de bombeiro.

2. O usuário final pode manipular este software, consultar e alterar as informações nele contidas.

3. É possível através do SIG determinar os pontos de perigo de incêndio dentro do município e identificar regiões com poucos pontos de abastecimento de água.

Para Gil (1999) a hipótese é uma suposta resposta ao problema a ser investigado. É uma proposição que se forma e que será aceita ou rejeitada somente depois de devidamente testada. O presente trabalho irá procurar validar as hipóteses acima citadas.

\subsection{Método de pesquisa e delineamento}

A metodologia de pesquisa empregada neste trabalho pode ser classificada como uma pesquisa-ação. Neste trabalho o pesquisador foi o responsável tanto pela implantação da ferramenta no posto de bombeiros como também do treinamento do pessoal. 
Partindo da concepção que método é um procedimento ou caminho para alcançar determinado fim e que a finalidade da ciência é a busca do conhecimento, pode-se dizer que o método científico é um conjunto de procedimentos adotados com o propósito de atingir o conhecimento. (LAKATOS e MARCONI, 1991).

O método a ser aplicado no trabalho tem o objetivo de descrever a ação executada dentro da organização para a implantação do SIG, utilizando um referencial teórico qualitativo-positivista. Para Martins (1995, p.37), o positivismo não aceita outra realidade que não sejam fatos que possam ser observados. Fatos estes que devem ter relações entre si, saindo da subjetividade para alcançar a objetividade científica através do uso de instrumentos (como questionários, escalas de atitude, escalas de opinião) e o uso da estatística.

A utilização deste método foi importante para verificar a possibilidade de criação de um SIG para solução do problema encontrado utilizando ferramentas simples e o aumento no nível de conhecimento da organização.

Para o delineamento deste trabalho foi escolhida a pesquisa-ação. Segundo Thiollent (1997) a pesquisa-ação é uma ação que visa mudança do mundo real que possui caráter participativo pelo fato de promover ampla interação entre pesquisadores e membros da situação investigada. Nela existe vontade de ação planejada sobre os problemas detectados na fase investigativa.

A pesquisa-ação tem por objetivo a melhoria da organização e o aumento do conhecimento das pessoas envolvidas.

Para Thiollent (1997, p.58), embora o projeto de pesquisa-ação não tenha forma totalmente predefinida, considera-se que ele tenha quatro fases as quais o presente trabalho pretende seguir:

1. A fase exploratória onde o pesquisador e os membros da organização detectam o problema.

2. A fase da pesquisa, onde dados são coletados e discutidos. 
3. A fase da ação, onde procurar propor soluções para o problema através de ações concretas.

4. A fase de avaliação, que tem por objetivo observar, redirecionar e resgatar o conhecimento produzido durante o processo.

Já para Coughlan e Coughlan (2002), a pesquisa-ação é uma ação e uma pesquisa, diferente da ciência positivista, que almeja apenas a criação conhecimento.

Entre as características da pesquisa-ação, Coughlan e Coughlan (2002) destacam que ela usa uma abordagem científica para estudar a resolução de importantes assuntos sociais ou organizacionais junto com aqueles que experienciam este assunto diretamente. A pesquisa-ação é participativa, pois os membros do sistema que está sendo estudado participam do ciclo de processo acima descrito. A pesquisa-ação é uma pesquisa convergente com a ação. O objetivo é criar uma ação mais efetiva enquanto constrói-se o conhecimento científico.

\subsection{A pesquisa qualitativa}

A abordagem utilizada neste trabalho é o da pesquisa qualitativa, usada em pesquisas sociais principalmente por antropólogos e sociólogos, vem nas últimas três décadas ganhando seu espaço em outras áreas, como a administração de empresas.

Godoy (1995) diferencia a pesquisa quantitativa da qualitativa. Na primeira o pesquisador conduz seu trabalho a partir de um plano pré-estabelecido, com hipóteses claramente especificadas e variáveis operacionalmente definidas.

A pesquisa quantitativa procura medir a quantificar resultados em busca de uma maior precisão. A pesquisa qualitativa por sua vez não procura enumerar ou medir eventos estudados, nem emprega a estatística para analisar os dados. Envolve a obtenção de dados descritivos sobre pessoas. Lugares e processos. A ênfase está no contato direto do pesquisador com a situação estudada. 
Godoy (1995) elenca algumas características básicas da pesquisa qualitativa:

1. A pesquisa qualitativa procura estudar e analisar o mundo em seu ambiente natural. $O$ pesquisador em contato com este ambiente utilizase de equipamentos para coleta de dados que vão desde anotações em papel até o uso de videoteipes e gravadores. O pesquisador tem um papel fundamental neste tipo de pesquisa fazendo a observação, análise, e interpretação dos dados coletados.

2. A pesquisa qualitativa rejeita a expressão quantitativa e numérica. Os dados devem ser descritivos, fazendo uma transcrição das entrevistas, anotações de campo, fotografias e outros documentos.

O pesquisador qualitativo deve estar preocupado com o processo e não simplesmente com os resultados do produto.

3. O pesquisador procurar compreender o fenômeno que está sendo estudado a partir da perspectiva dos participantes.

4. Pesquisadores procuram usar a indução para analisar seus dados, partindo de questões mais amplas que vão se tornando mais diretas e específicas no transcorrer das investigações. 


\section{Corpo de Bombeiros}

Segundo BRASIL. Constituição. (1988), "segurança pública dever do Estado, direito e responsabilidade de todos, é exercida para a preservação da ordem pública e da segurança das pessoas e do patrimônio".

Os órgãos públicos responsáveis por esta tarefa são: polícia federal, polícia rodoviária federal, polícia ferroviária federal, polícias civis, polícias militares e corpo de bombeiros militares. Este último sendo participante desta pesquisa.

Ainda segundo BRASIL. Constituição. (1988):

"Os corpos de bombeiros militares são os órgãos do sistema de segurança pública aos quais compete a execução das atividades de defesa civil, além de outras atribuições específicas estabelecidas em lei."

Ao corpo de bombeiros compete a prevenção e combate a incêndio, salvamentos e resgates.

O corpo de bombeiros, através da lei n. 616 de 17 de Dezembro de 1974, Artigo Segundo, Inciso V, determina que:

"Compete à Polícia Militar realizar serviços de prevenção e de
extinção de incêndios, simultaneamente como de proteção e
salvamento de vidas humanas e material no local do sinistro, bem
como o de busca e salvamento, prestando socorros em casos de
afogamento, inundações, desabamentos, acidentes em geral,
catástrofes e calamidades." (SÃO PAULO, 1974)

O combate a incêndio é umas das principais tarefas do corpo de bombeiros.

Para que o atendimento a uma ocorrência de incêndio obtenha sucesso, três fatores são essências. O primeiro diz respeito a estrutura do corpo de bombeiros com equipamentos, viaturas e pessoas. Em segundo, a infraestrutura do município com vias de acesso rápido a bairros e rede de água que possa ser usada no combate ao incêndio. Em terceiro, acesso a informação rápida e precisa em situações de emergência. 
Para justificar a necessidade de propor soluções para o problema descrito no capítulo anterior, vale citar o exemplo do edifício Joelma ocorrido em 01 de fevereiro de 1974 que matou 188 pessoas.

Os bombeiros viram a importância de equipamentos adequados para combater incêndios de grandes proporções como o do Joelma. O edifício não possuía heliporto e o teto não permitia o pouso de helicópteros. Mais de 30 viaturas foram deslocadas para o local do incêndio, mas as escadas Magirus de 45 metros não alcançaram os andares superiores. Por não haver uma quantidade suficiente de hidrantes próximos ao local, faltou água. Os bombeiros chegaram a fazer um apelo aos moradores das vizinhanças por intermédio dos megafones: "Quem tiver água e possa trazê-la até aqui num balde, por favor, faça com urgência. Estamos precisando de água. Atenção, moradores, tragam água em baldes." (DE NOVO..., 1974).

A água é o agente mais eficaz para o resfriamento. A aplicação da água será bem-sucedida se a quantidade utilizada for suficiente para resfriar 0 combustível que está queimando para temperaturas que o conduzam abaixo do ponto de combustão.

Os bombeiros possuem equipamentos de ataque a incêndio, que se diferem principalmente na dimensão e que determinam em situação devem ser usados. Um dos equipamentos utilizados é o canhão de água que fica acoplado à viatura. Ele possui uma vazão de 1.325 e 7.570 litros por minuto e o alcance do seu jato varia entre 30 e 60 metros.

No que se refere às viaturas, a mais utilizada pelo bombeiro nas operações de combate a incêndio é a Auto-Bomba $(A B)$. Todo $A B$ possui bomba de incêndio (de 2.000 a 8.000 litros por minuto) e tanque (de 3.000 a 6.000 litros) para transporte de água até o local do incêndio.

Analisando estas informações podemos observar que em uma situação de combate a incêndio como no Edifício Joelma, em que vários andares estavam em chamas e que foi necessário o uso de um canhão de água, acoplado a veículos do tipo Auto Bomba, a água armazenada no tanque se esgota em 
menos de um minuto, levando-se em consideração a vazão máxima do canhão.

\subsection{Histórico do Corpo de Bombeiros do Estado de São Paulo}

Este breve histórico foi baseado em informações do CORPO DE BOMBEIROS DO ESTADO DE SÃO PAULO (2004):

O serviço de extinção de incêndio foi criado em 2 de maio de 1856, pelo então Imperador D.Pedro II, através do Decreto Imperial $n^{\circ} 1.775$. Nessa época, o sinal de incêndio, era dado através do badalar dos sinos que alertava homens, mulheres e crianças que ficavam em fila e, do poço mais próximo, passavam baldes de mão em mão, até chegarem ao local que estivesse em chamas.

Em 1874, foi feita a primeira tentativa de estabelecimento de um serviço de bombeiros agregados à Companhia de Urbanos (Guardas-civis) em São Paulo, tendo como efetivo 10 homens. Como a lei não estabelecia qual era a prioridade dos Urbanos, se policiamento ou combate a incêndios, logo esta função foi abandonada, e os bombeiros designados para policiamento das ruas.

Em 1880, foi criada a instituição, logo após um incêndio na Faculdade de Direito, que funcionava no Convento de São Francisco hoje Faculdade de Direito do Largo São Francisco, ocorrido em 15 de Fevereiro do referido ano. Na época, a cidade de São Paulo não contava com o serviço de bombeiros; este serviço era executado pelo Corpo Policial, sendo auxiliados por civis em caso de necessidade; não havia equipamento próprio para o combate a incêndio, apenas duas bombas manuais.

No ano seguinte, foi inaugurado o sistema de águas da capital, e implantadas diversas válvulas para auxiliar o serviço dos bombeiros. Estas válvulas foram as precursoras do sistema de hidrantes utilizados hoje no combate a incêndios.

Em 1886 foi formalizado um código com normas de combate a incêndio, chamado de Código de Posturas, que se previa dentre outras coisas, que os encarregados dos sinos das igrejas dessem o alarme quando soubessem de um incêndio; avisos falsos seriam punidos com pesadas multas e prisão. Esta 
era uma forma rudimentar de comunicação, mas que evidencia a importância da rapidez em comunicar o inicio de um incêndio.

Os aguadeiros (transportadores de pipas) tinham, por força da lei, de comparecer ao local do sinistro, e os poços ficavam franqueados aos bombeiros. O Código também premiava em dinheiro aqueles que, em não sendo bombeiros, tivessem o melhor desempenho em caso de incêndio. Fica evidenciada aqui a preocupação que existia em relação aos recursos necessários para a extinção do incêndio.

Em Novembro de 1891 é criado o Corpo de Bombeiros, com um efetivo de 240 homens selecionados e treinados. Neste mesmo ano a companhia telefônica montou 50 aparelhos telefônicos para agilizar o aviso de incêndio. No local da ocorrência era utilizada a corneta e nas ruas foi instalado um sistema de alarme alemão que só seria desativado por volta de 1920.

Ainda no final do século XIX foram instaladas 50 caixas de aviso de incêndio, chamadas "linhas telegráficas de sinais de incêndio", com cerca de 70 quilômetros de extensão, operadas por telegrafistas. Este sistema representou uma grande evolução, mas alguns bairros mais distantes ficaram desprovidos deste recurso. Os hidrantes disponíveis, embora tenham aumentado quantitativamente, ainda eram insuficientes, e a distância entre eles dificultava a ação dos bombeiros. De acordo com pesquisa feita no IBGE (2004), São Paulo no final do século XIX tinha uma população estimada em 239.820 habitantes.

Em 1895, começam a operar novos veículos e materiais. Os veículos de tração animal foram desativados apenas em 1921. Durante as primeiras décadas do século XX o corpo de bombeiros passou por evoluções tanto técnicas como administrativas. Foram adquiridos veículos automotores, já que os veículos de tração animal demoravam muito para chegar ao local de incêndio. Foram criadas novas funções como a de mecânico e carpinteiro. Em 1912 ocorreu a publicação do segundo manual da corporação chamado "Noções Práticas do Serviço de Bombeiros". 
Em 1922, o oficial Affonso Luiz Cianciulli projetou o desenvolvimento de uma bomba, que se tornou o primeiro equipamento de combate a incêndio produzido no Brasil e que foi chamado de "Bomba da Independência". Cianciulli viria mais tarde, em 1929 a comandar a corporação e introduzir novas técnicas de combate a incêndio e treinamento de pessoal. De acordo com pesquisa feita no IBGE (2004), a cidade de São Paulo nesta época já contava com mais de 570 mil habitantes.

No início da década de 40, os bombeiros começaram a se instalar no interior do Estado de São Paulo. Em Campinas eles estavam presentes desde o ano de 1900.

Baseado na REVISTA DO CORPO DE BOMBEIROS (2002), a região estudada, que compreende os municípios próximos à Rio Claro, São Carlos foi uma das primeiras cidades a ter um posto de bombeiros instalado em 21 de abril de 1952.

O município de Piracicaba por sua vez fundou seu posto de bombeiros em 01 de agosto de 1956. Atualmente esta cidade é sede do $16^{\circ}$ Grupamento de Bombeiros.

Os postos de outros municípios vieram anos mais tarde. Em Limeira, o primeiro posto foi inaugurado em 1969. O posto do Município de Araras foi criado em 18 de janeiro de 1973.

Em Rio Claro houve uma campanha para a instalação do posto de bombeiros iniciada em 03 de abril de 1979 através do Rotary Club Sul de Rio Claro. A campanha teve como símbolo uma vela acesa que ficava exposta em uma vitrine de uma loja no centro do município. A chama desta vela seria apagada apenas no dia da inauguração do posto de bombeiros. Para tanto, foram usadas 117 velas do tipo sete dias e sete noites. No dia 18 de Dezembro de 1981, foi oficialmente inaugurado o Corpo de Bombeiros de Rio Claro. Tendo, como primeira atividade de combate a incêndio, apagar a referida vela acesa.

Juntamente com a instalação de postos no interior do Estado, vieram algumas melhorias como a rede de rádio inaugurada em 1955, que procurava facilitar a 
comunicação entre as viaturas e o quartel, o qual tinha a função de informar o melhor caminho e a situação da ocorrência. Um ano depois foram eliminadas as caixas de alarme e adotado o sistema telefônico. Pesquisa feita no IBGE (2004) constatou que nesta época o número de telefones era pequeno: 168.278 aparelhos instalados no Estado de São Paulo no início da década de 50, para uma população de 9.242 .610 habitantes. A adoção do número telefônico 193 como padrão em todos os municípios foi adotado apenas em 1978.

Ainda segundo o CORPO DE BOMBEIROS DO ESTADO DE SÃO PAULO (2004), na década de 50 o Brasil começou a usar novas técnicas trazidas do exterior através das viagens de alguns oficiais para os Estados Unidos. Equipamentos de combate a incêndio foram importados para equipar os postos de bombeiros que estavam surgindo. Havia um grande emprego de carrostanque, sendo o hidrante um equipamento secundário que era pouco utilizado. No início da década de 60 , em virtude do número de edifícios presentes no município de São Paulo, o Corpo de Bombeiros passou a exigir a instalação de hidrantes e extintores nos edifícios. O cumprimento desta norma era garantido pelo Departamento de Águas de São Paulo, atual SABESP, que não fornecia água para o consumo caso o projeto não fosse aprovado pela corporação.

Na década de 1970, ocorreram no município de São Paulo dois incêndios que provocaram a adoção de novas leis de segurança.

De acordo com Rodrigues (1994, p.4) "A discussão sobre leis, segundo o exdiretor do Contru, Carlos Venturelli, começou depois do incêndio no Andraus, em 1972, na avenida São João, no centro da cidade. Foram 16 mortos e 300 feridos."

Ainda segundo Rodrigues (1994), os estudos sobre segurança em edifícios já estavam sendo deixados em segundo plano, quando ocorreu o incêndio do edifício Joelma, em 01 de fevereiro de 1974, provocando a morte de 188 pessoas. "Naquele ano, a prefeitura baixou o decreto municipal que obrigava os prédios, num prazo de 90 dias, a executar as obras de segurança". Segundo o corpo de bombeiros "Depois do Joelma, além de hidrantes e extintores, os 
prédios foram obrigados a fazer escadas de segurança, instalar alarme, iluminação de emergência e brigadas de incêndio".

A legislação de 1974 não previa multas nem interdições para quem não executasse as obras. A aplicação de multas só veio depois do incêndio do edifício Grande Avenida, na Avenida Paulista, em 1981, que matou 17 pessoas. A lei foi promulgada no ano seguinte.

Ainda segundo o CORPO DE BOMBEIROS DO ESTADO DE SÃO PAULO (2004), na década de 1990 o corpo de bombeiros coloca em prática o Serviço de Resgate com atuação na Grande São Paulo e em 14 municípios do estado. Este serviço é consolidado através do Decreto Lei $n^{\circ} 38.432$, garantindo sua operacionalização através da Polícia Militar do Estado de São Paulo, por intermédio do Corpo de Bombeiros e do Grupamento de Rádiopatrulha Aérea.

\subsection{0 fogo como um problema socioeconômico.}

Segundo Jennings (1999, p.8), incêndios residenciais são causados pela interação de fatores sociais, ambientais e econômicos. Avanços tecnológicos como a lâmpada elétrica e o aquecedor a gás trouxeram benefícios mas também criaram fontes de ignição para o fogo dentro das residências.

A isto se soma o crescimento muitas vezes desordenado das cidades que favoreceu o declínio da infraestrutura e proporcionou o aumento no número de incêndios.

Este panorama começou a surgir a partir do início do século XX. Nesta época começaram a surgir as primeiras normas de construção de edifícios para proteção contra incêndios. (THOMSON, 1997).

Algumas normas instituídas foram:

1. Instalação de mangueiras nos edifícios

2. Construção de elevadores fechados para evitar a propagação de fumaça

3. Instalação de um sistema de abastecimento de água separado. 
4. Instalação de um hidrante em frente à prédios altos onde existem reservatórios de água.

Jennings (1999) constatou ainda que a pobreza e o abandono do imóvel têm relação direta com o fogo. Segundo o autor o abandono e o declínio do imóvel pode ser considerado um fenômeno contagioso. Ou seja, os imóveis próximos ao imóvel abandonado tendem a ter o mesmo fim. Estes imóveis não recebem a devida manutenção e quando passam a abrigar um inquilino a tendência de incêndio é maior.

Estudos de caso mostraram que os incêndios residenciais estão associados à pobreza, grande quantidade de pessoas na residência, supervisão inadequada de crianças, abuso de álcool e drogas, falta de detectores de fumaça e descuido por parte de adultos.

Ainda segundo Wallace e Wallace $^{1}$ (1993 apud JENNINGS, 1999, p.11) os incêndios são mais freqüentes onde existe um grande número de pessoas dividindo uma mesma casa e onde há falta de saneamento básico.

Deve-se levar em conta o fato de que as pessoas que residem nestas áreas possuem baixo nível de educação, o que segundo Karter e Donner ${ }^{2}$ (1977 apud JENNINGS, 1999, p.18) têm relação direta com o aumento das taxas de incêndio.

Diante deste cenário Beyler (2001), sugere alguns desafios na prevenção de incêndios para os próximos anos:

1. Desenvolver melhores padrões para produção de dispositivos de segurança contra incêndios.

1 WALLACE, R.; WALLACE, D. (1993). The coming crisis of public health in the suburbs. The Milbank Quarterly, v.71, n.4, p.545 apud JENNINGS, C.R. (1999). Socioeconomic characteristics and their relationship to fire incidence: a review of the literature. Fire Technology, v.35, n.1, p.7-29.

${ }^{2}$ Karter, Michael Jr., and Donner, Allan, "Fire Rates and Census Characteristics-An Analytical Approach," Boston: National Fire Protection Association, July 1977, p. 4. apud JENNINGS, C.R. (1999). Socioeconomic characteristics and their relationship to fire incidence: a review of the literature. Fire Technology, v.35, n.1, p.7-29. 
2. Desenvolver melhores métodos para identificar falhas em produtos e instalações.

3. Identificar e desenvolver atividades educacionais a respeito de segurança e proteção contra incêndios.

4. Desenvolver métodos para avaliar custos de prevenção de incêndios.

5. Revigorar a pesquisa sobre o fogo e promover fundamentos para a engenharia de proteção de incêndios.

\subsection{O combate a incêndio}

O combate a incêndio está fundamentado nos seguintes pilares: utilização de técnicas e equipamentos adequados de extinção de incêndio; abastecimento e comunicação.

O objetivo deste capítulo é mostrar que água é um elemento essencial na extinção de incêndios, com exceção de algumas situações onde o material em combustão não deve receber água para seu resfriamento e sim outros produtos mais eficazes.

\subsection{Como surge o fogo}

De acordo com CONCEITOS.... (2001), o fogo pode ser definido como um fenômeno físico-químico onde se tem lugar uma reação de oxidação com emissão de calor e luz.

O fenômeno do fogo é composto por quatro componentes:

1. Combustível: é qualquer substância capaz de produzir calor por meio da reação química.

2. Comburente: é o componente que alimenta a reação química, sendo mais comum o oxigênio.

3. Calor: uma forma de energia que se transfere de um sistema para outro em virtude de uma diferença de temperatura. Pode ter como 
fonte à energia elétrica, o cigarro aceso, os queimadores a gás, a fricção ou mesmo a concentração da luz solar através de uma lente.

4. Reação em cadeia.

Incêndio pode ser definido como sendo o fogo indesejável, qualquer que seja sua dimensão. Os focos de incêndio, deste modo, originam-se em locais onde fonte de calor e materiais combustíveis são encontrados juntos, de tal forma que ocorrendo decomposição do material pelo calor são desprendidos gases que podem se inflamar.

\subsection{Evolução de um Incêndio}

A evolução do incêndio em um local pode ser representada por um ciclo com três fases características:

\begin{tabular}{|c|c|}
\hline $\begin{array}{l}\text { Fase inicial de elevação } \\
\text { progressiva da temperatura } \\
\text { (ignição) }\end{array}$ & $\begin{array}{l}\text { Inicia-se como ponto de inflamação inicial e caracteriza-se por } \\
\text { grandes variações de temperatura de ponto a ponto, } \\
\text { ocasionadas pela inflamação sucessiva dos objetos existentes } \\
\text { no recinto, de acordo com a alimentação de ar. }\end{array}$ \\
\hline Fase de aquecimento & $\begin{array}{l}\text { O fogo propaga-se de um material para outro. As portas e } \\
\text { janelas influenciam esta propagação devido a quantidade de } \\
\text { oxigênio que entra no ambiente. }\end{array}$ \\
\hline $\begin{array}{l}\text { Fase de resfriamento e } \\
\text { extinção }\end{array}$ & $\begin{array}{l}\text { Nesta fase o material combustível já foi queimado e o fogo } \\
\text { tende a se extinguir. O desenvolvimento e a duração de um } \\
\text { incêndio são influenciados pela quantidade de combustível a } \\
\text { queimar. }\end{array}$ \\
\hline
\end{tabular}

Quadro 1 - Fases do incêndio

Fonte: CONCEITOS... (2001)

\subsection{Técnicas de extinção de incêndios}

De acordo com o Manual (1997c, p.3), "técnica de extinção de incêndio é a utilização correta dos meios disponíveis para extinguir incêndios com maior segurança e com um mínimo de danos durante o combate”.

O combate a incêndio é feito através de uma guarnição de bombeiros, onde segundo o Manual (1997c, p.3), cada membro tem sua função definida:

1. O Comandante da guarnição toma decisões para o desenvolvimento tático, assiste e supervisiona os integrantes da guarnição quanto aos procedimentos técnicos. 
2. O motorista conduz o veículo em segurança e tem a função de operar a bomba. Além disso, tem a função de conduzir a viatura até o local de abastecimento se necessário.

3. Os chefes de linha e auxiliares operam os esguichos e realizam outras missões conforme determinação do Comandante.

\subsection{Classes de incêndio}

\subsubsection{Incêndio Classe "A"}

O Manual (1997c, p.3) refere-se ao incêndio da classe "A" como originado de combustíveis comuns como (papel, madeira, tecidos) que deixam resíduos característicos (brasa, carvão, cinza), em geral são extintos por resfriamento através da água, podendo utilizar também a técnica de abafamento, retirada do material e quebra da reação em cadeia.

A água nesta situação é o agente mais eficaz para o resfriamento. A água deve ser aplicada de forma que o combustível que está queimando fique em temperatura abaixo do ponto de combustão.

\subsubsection{Incêndio "Classe B"}

"São incêndios em líquidos e gases inflamáveis que, por terem características próprias, possuem métodos de extinção distintos". (MANUAL 1997c, p. 6).

Os incêndios da classe $B$ são eliminados utilizando-se a técnica de abafamento, resfriamento por água e ainda a retirada de material. $O$ resfriamento por água deve ser feito utilizando o jato em estilo "chuveiro". O jato de água contínuo não deve ser utilizado pois espalharia o liquido em chamas aumentando o incêndio.

Para que o combate a este tipo de incêndio tenha sucesso, é importante que se conheça algumas características dos líquidos inflamáveis:

1. Geram vapores inflamáveis à temperatura ambiente

2. Flutuam na água 
3. Queimam rapidamente sobre a superfície exposta ao calor

4. Liberam durante a queima grande quantidade de calor.

\subsubsection{Incêndio Classe "C"}

De acordo com o Manual (1997c, p.6), são os incêndios que atuam sobre materiais energizados por corrente elétrica. Neste tipo de incêndio o uso da água exige maior cautela, pois existe o risco de choque elétrico. Ela contém impurezas que a tornam condutora de eletricidade. Este tipo de incêndio pode ser eliminado com mais facilidade se a energia elétrica puder ser cortada. Desta forma o incêndio deixa de ser classe "C" e passa para classe "A" ou "B".

Agentes extintores que não conduzem eletricidade devem ser usados no combate a este tipo de incêndio.

\subsubsection{Incêndio Classe" $D$ "}

O Manual (1997c, p.8), define este tipo de incêndio como: "incêndios em metais combustíveis (magnésio, selênio, antimônio, lítio, cádmio, potássio, alumínio, zinco, titânio, sódio, zircônio) exigem, para a sua extinção, agentes que se fundam em contato com o material ou que retirem o calor destes." Metais combustíveis queimam em temperaturas extremamente altas e reagem com a água, arremessando partículas.

Ainda de acordo com o Manual (1997c) A cor branca das chamas caracteriza este tipo de incêndio. É possível que uma camada cinza cubra o material, dando a impressão de que o fogo não existe.

Um problema enfrentado pelo bombeiro numa emergência com combustíveis classe "D" é a obtenção de agentes extintores adequados à situação específica. Isso porque os metais combustíveis não apresentam um comportamento padrão para um determinado agente extintor. Desta forma, deve-se agir com cuidado nestes casos. O melhor método de extinção é o abafamento. 
Este tipo de incêndio será extinto com o emprego de agentes especiais, tais como grafite seco, cloreto de sódio, areia seca e nitrogênio.

Em certas circunstâncias, a água pode ser usada como agente extintor (nas situações específicas de ligas de magnésio usadas em indústria). Neste caso, a água deve ser utilizada em grandes quantidades, pois a temperatura deste tipo de fogo é muito alta e a técnica de extinção utilizada é o resfriamento.

\subsection{Formas de extinção de incêndio}

\subsubsection{Ataque direto}

O bombeiro deve estar próximo ao incêndio, utilizando jato contínuo ou chuveiro a cerca de 30 graus ou menos, sempre concentrando o ataque para a base do fogo, até extingui-lo.

\subsubsection{Ataque Indireto}

$O$ ataque indireto é feito através de um método de vaporização da água, sem que o bombeiro entre no ambiente. É comumente executado quando o ambiente está confinado e com alta temperatura, com ou sem fogo.

Realiza-se dirigindo $\circ$ jato d'água para o teto superaquecido, tendo como resultado a produção de aproximadamente 1.700 litros de vapor, à pressão normal e temperatura superior a $100^{\circ} \mathrm{C}$.

No ataque indireto, o esguicho será acionado por um período de 20 a 30 segundos. Não deverá haver excesso de água, o que causaria distúrbios no balanço térmico.

O Manual (1997c, p.9) determina que a quantidade de água a ser empregada em um compartimento deve ser calculada levando em consideração a seguinte fórmula:

$\mathrm{Q}=1,5 \times$ volume do ambiente $(\mathrm{m} 3)$

Onde

$Q=$ litros por minuto (vazão) 
Volume = área $\mathrm{x}$ altura

EXEMPLO :

Um salão com as seguintes medidas :

Largura :10m

Comprimento : $24 \mathrm{~m}$

Altura : $3 m$

$10 \mathrm{~m} \times 24 \mathrm{~m}=240 \mathrm{~m}^{2} \times 3 \mathrm{~m}($ altura $)=720 \mathrm{~m}^{3}$ (volume $)$

$\mathrm{Q}=1,5 \times 720=1.080$ litros por minuto $(\mathrm{Ipm})$

Essa vazão (Q) deve ser aplicada por 30 segundos.

Um esguicho regulável de $38 \mathrm{~mm}$, com $5,5 \mathrm{~kg} / \mathrm{cm} 2$ (80psi) de pressão, descarrega aproximadamente $360 \mathrm{lpm}$. Portanto, é necessária a utilização de 3 esguichos simultaneamente, por 30 segundos, procurando atingir todo o teto do compartimento $(1.080 / 360=3)$.

Logo após a utilização dos esguichos de água, o bombeiro aguarda a estabilização do ambiente, até que as labaredas baixem e se reduzam a focos isolados.

A aplicação de água somente será bem-sucedida se a forma e a quantidade utilizada for adequada e suficiente.

Para isso, a seleção de linhas (mangueira ou canhão) e jatos dependerá das necessidades da situação, tais como:

1. Volume de água disponível e o necessário para a extinção

2. Alcance do jato

3. Número de pessoas disponíveis para manobrar as linhas

4. Mobilidade exigida 
5. Tática e técnica escolhida.

Cada situação deve usar a linha e jato adequado. Leva-se em consideração variáveis como o tamanho da área incendiada, a distância segura em que os bombeiros devem ficar para combater o fogo, a mobilidade que a linha deverá ter e a quantidade de pessoal disponível.

Por exemplo, para eliminar um incêndio numa grande ocupação comercial totalmente envolvida pelo fogo, não seria aconselhável utilizar uma linha direta de $38 \mathrm{~mm}$, ou ainda o mangotinho. $O$ ataque não teria o volume nem o alcance necessários. Utilizar uma linha de $63 \mathrm{~mm}$, descarregando 940 litros por minuto em um dormitório de residência familiar em chamas também é incorreto.

Outro erro que deve ser evitado é armar uma linha com grande vazão de água não havendo reserva d'água (hidrante público) disponível. Uma linha de $63 \mathrm{~mm}$ com grande vazão como exemplificado, esgotaria em menos de 5 minutos um caminhão auto-bomba com 4.000 litros de água. 
O Manual (1997c) possui um quadro com as características de linha de ataque:

\begin{tabular}{|c|c|c|c|c|}
\hline $\begin{array}{l}\text { Tipo } \\
\text { (dimensão) }\end{array}$ & $\begin{array}{l}\text { Mangotinho } \\
\text { (16 a } 25 \mathrm{~mm} \text { ) }\end{array}$ & $\begin{array}{l}38 \mathrm{~mm} \\
\left(11 / 2^{\prime \prime}\right)\end{array}$ & $\begin{array}{l}63 \mathrm{~mm} \\
\left(21 / 2^{\prime \prime}\right)\end{array}$ & Canhão \\
\hline Vazão & 39 a 114 Ipm & 190 a 454 Ipm & 560 a 946 Ipm & 1.325 a $7.570 \mathrm{lpm}$ \\
\hline $\begin{array}{l}N^{0} \text { pessoas no } \\
\text { Esguicho }\end{array}$ & 01 & 01 ou 02 & 02 a 04 & 01 \\
\hline Mobilidade & Excelente & Boa & $\begin{array}{l}\text { Reduzida a } \\
\text { moderada }\end{array}$ & $\begin{array}{l}\text { Reduzida ou nula } \\
\text { (esguichos / torre d'água } \\
\text { podem ter } \\
\text { mobilidade maior) }\end{array}$ \\
\hline Controle de perdas & Excelente & Bom & Moderado & Difícil \\
\hline $\begin{array}{l}\text { Controle de } \\
\text { direção }\end{array}$ & Excelente & Excelente & Bom & Bom \\
\hline
\end{tabular}

Quadro 2 - Características das linhas de ataque a incêndio.

Fonte: adaptado de Manual (1997c)

\subsection{Elementos decisivos para o combate ao incêndio.}

Durante o combate a qualquer uma das classes de incêndios citadas anteriormente alguns elementos são imprescindíveis para o sucesso da operação. Serão abordados três elementos relacionados à presente pesquisa que são: equipamentos utilizados pelos bombeiros, em especial as viaturas; o processo de abastecimento dos veículos em situações de combate a incêndios, incluindo o uso de hidrantes e outras formas de abastecimento; e por último a comunicação entre o posto de bombeiros e a guarnição que está atuando no sentido de fornecer informações rápidas e precisas sobre os locais de abastecimento.

\subsubsection{Veículos}

Entre os veículos para combate a incêndio, destaca-se o Auto Bomba (AB), o Auto Tanque (AT), a jamanta e o carro-pipa 
De acordo com o Manual (1997a, p.4), "todo Auto Bomba possui grande quantidade e variedade de material para combate a incêndio e uma bomba cuja vazão varia entre 2.000 e 8.000 litros por minuto (Ipm), e um tanque com capacidade entre 3.000 e 6.000 litros."

A principal função do Auto Tanque é o abastecimento do Auto Bomba como da jamanta. Possui capacidade de transporte de 4.000 a 10.000 litros de água. Raras são as situações em que o Auto Tanque é utilizado no combate a incêndio, pois sua bomba possui pequena capacidade de vazão e de manobra.

A jamanta por sua vez possui capacidade de transportar um grande volume de água, até 16.000 litros. Tem a função de abastecer o $A B$ em locais de incêndio sem hidrantes próximos.

Os carros-pipa são veículos para transporte de água pertencente ao serviço de distribuição de água. Podem ser públicos ou privados. Em caso de necessidade os bombeiros utilizam estes veículos para auxiliar o abastecimento.

O quadro abaixo resume as características destes veículos:

\begin{tabular}{|c|c|c|}
\hline TIPO DE VEÍCULO & FUNÇÃO & CARACTERÍSTICAS \\
\hline AB (auto-bomba) & $\begin{array}{l}\text { Veículo de combate a } \\
\text { incêndio }\end{array}$ & $\begin{array}{l}\text { Pequeno volume de água; } \\
\text { capacidade e diversidade de manobras de } \\
\text { bomba. }\end{array}$ \\
\hline AT (auto-tanque) & $\begin{array}{l}\text { Abastecimento } \\
\text { AB/JAMANTA }\end{array}$ & $\begin{array}{l}\text { Médio volume de água; } \\
\text { poucas opções de manobra de bomba. }\end{array}$ \\
\hline $\begin{array}{l}\text { CAVALO-MECÂNICO + } \\
\text { REBOQUE } \\
\text { (CM) (Jamanta) }\end{array}$ & Abastecimento do $A B$ & $\begin{array}{l}\text { Grande volume de água } \\
\text { tracionado por } \mathrm{CM} \text {; } \\
\text { moto-bomba acoplada. }\end{array}$ \\
\hline CARRO-PIPA & $\begin{array}{l}\text { Abastecimento de } \\
\text { JAMANTA/AB/AT }\end{array}$ & $\begin{array}{l}\text { Médio volume de água; } \\
\text { grande quantidade de veículos disponível. }\end{array}$ \\
\hline
\end{tabular}

Quadro 3 - Classificação dos veículos do serviço de bombeiros.

Fonte: adaptado de Manual (1997a, p.4)

Outras características dos veículos

Os veículos acima descritos são montados por empresas brasileiras. Em geral possuem as praticamente as mesmas características não havendo grandes diferenças entre as marcas disponíveis no mercado brasileiro. De acordo com a MITREN (2004), montadora de veículos, algumas características são comuns, tais como: 
- O chassi, que deve permitir a acomodação de toda a estrutura através de uma distancia entre eixos que suporte todo o peso.

- Bombas acionadas pelo próprio motor do veículo, através do cardã ou por sua tomada de força.

- Tanques de água em aço inoxidável ou em aço carbono tratado. Montados sobre coxins de borracha e com quebra-ondas que garantem a dirigibilidade do veículo.

- Estruturas em tubos retangulares de alumínio liso ou em aço carbono, soldados e revestidos com chapas de alumínio.

\subsubsection{Abastecimento}

"O abastecimento dos veículos pode ser feito através de mananciais, piscinas, hidrantes particulares ou públicos e também através de outros veículos." (MANUAL, 1997a, p.1).

O hidrante é o principal meio de abastecimento dos veículos em situações de incêndio. Mananciais e piscinas nem sempre são encontrados facilmente para abastecer um veículo. Outras alternativas de abastecimento são:

1. Mananciais: rios, lagos, córregos, mares, represas, poços, etc. A utilização de mananciais depende de bombeamento, geralmente através de sucção (onde a água é retirada de um manancial situado abaixo do nível da bomba). A água salgada não é aconselhada pois o sal danifica os equipamentos.

2. Reservatórios: são depósitos de água como piscinas, fontes públicas, espelhos d'água.

3. Viaturas: devido a ineficiência da rede de distribuição de água, o serviço de bombeiros utiliza viaturas como fonte de abastecimento de água. Entre estas viaturas estão o Auto-Tanque que possui capacidade de transportar de 4.000 a 10.000 litros de água. São usados também carros pipas do serviço de abastecimento de água do município. 
4. Hidrantes: são dispositivos colocados nas redes de distribuição que permitem a captação de água pelos bombeiros. Estes hidrantes podem ser públicos ou particulares. Os hidrantes são classificados pelos bombeiros em vermelhos, amarelos e verdes. Os hidrantes vermelhos possuem uma pequena vazão e demoram a abastecer uma viatura. Os hidrantes amarelos têm vazão média, enquanto que os hidrantes verdes por sua vez têm uma grande vazão e abastece uma viatura com maior rapidez.

5. Registros de Recalque: são registros colocados em calçadas defronte a prédios e que permite o bombeiro abastecer a viatura utilizando a água armazenada nos reservatórios destes prédios.

\subsubsection{Importância dos pontos de abastecimento}

Para justificar a importância dos pontos de abastecimento no combate a incêndio, cabe citar o caso do incêndio da indústria de bebidas Vila Velha ocorrido em 15 de julho de 1994, em Rio Claro - SP. De acordo com Relatório (1994), esta indústria produzia aguardente e estava localizada zona na urbana, em uma área de $3.880 \mathrm{~m}^{2}$, ao lado de uma avenida de acesso ao centro da cidade. Na época, a indústria armazenava 1.200.000 litros de aguardente. $\mathrm{O}$ incêndio começou por volta das 17 horas e 30 minutos com a explosão de um equipamento na linha de produção. Toda operação durou 9 horas e contou com a utilização de 9 viaturas. Foram utilizados cerca de 450.000 litros de água. Destes, apenas 30.000 litros vieram das viaturas. O restante foi obtido em um hidrante a cerca de 100 metros do local onde os veículos eram abastecidos. Este hidrante possui uma vazão de 3.800 litros por minuto (lpm), o que é considerado uma boa vazão para abastecimento. 


\begin{tabular}{|c|c|c|}
\hline \multicolumn{3}{|c|}{$\begin{array}{l}\text { Hidrantes públicos - são hidrantes da rede de distribuição pública de água. Podem } \\
\text { captar grandes quantidades de água. }\end{array}$} \\
\hline & Local de instalação & Características \\
\hline Hidrantes de coluna & $\begin{array}{l}\text { São instalados nas } \\
\text { calçadas. }\end{array}$ & $\begin{array}{l}\text { Permite captação de maior volume de água. } \\
\text { Fica mais visível e é mais difícil de ser } \\
\text { obstruído. }\end{array}$ \\
\hline Hidrantes subterrâneos & $\begin{array}{l}\text { São situados abaixo } \\
\text { do nível do solo }\end{array}$ & $\begin{array}{l}\text { Suas partes são colocadas dentro de caixas } \\
\text { de alvenaria, com tampa metálica. É menos } \\
\text { visíveis e fácil de ser obstruído. }\end{array}$ \\
\hline \multicolumn{3}{|c|}{ Hidrantes particulares - são alimentados por caixa de água elevada ou subterrânea. } \\
\hline Hidrantes de parede & $\begin{array}{l}\text { Dentro dos edifícios, } \\
\text { colocados em } \\
\text { abrigos ou } \\
\text { projetados para fora } \\
\text { da parede. }\end{array}$ & $\begin{array}{l}\text { Podem ser usados pelos próprios moradores } \\
\text { do edifício para início do combate ao incêndio. }\end{array}$ \\
\hline Registro de recalque & $\begin{array}{l}\text { Situados abaixo do } \\
\text { nível do solo, na } \\
\text { calçada, junto à } \\
\text { entrada principal da } \\
\text { edificação. }\end{array}$ & $\begin{array}{l}\text { Suas partes são colocadas dentro de caixas } \\
\text { de alvenaria, com tampa metálica. É usado } \\
\text { pelos bombeiros para abastecer a viatura } \\
\text { utilizando a água armazenada no reservatório } \\
\text { do edifício. }\end{array}$ \\
\hline
\end{tabular}

Quadro 4 - Tipos de hidrantes.

Fonte: adaptado de Manual (1997a)

Os hidrantes de coluna e os registros de recalque são os principais objetos deste estudo por serem os mais comuns. Os hidrantes de parede são difíceis de serem quantificados além do fato de não permitirem o abastecimento das viaturas.

De acordo com HIDRANTES... (2001) devido à dificuldade de visualização, a grande possibilidade de obstrução e de contaminação da água, recomenda-se que não seja mais aceita a instalação de hidrante do tipo subterrâneo na rede pública de distribuição de água e nas redes dos loteamentos e condomínios. Recomenda-se que este tipo de hidrante seja gradativamente desativado e substituído por hidrantes de coluna. 
Os hidrantes são identificados através de cores e classificados de acordo com sua vazão.

\begin{tabular}{lll}
\hline Vazão & Cor & Identificação \\
\hline Até $1.000 \mathrm{lpm}$ & Vermelho \\
\hline Entre 1.000 e $2.000 \mathrm{lpm}$ & Amarelo \\
\hline Acima de $2.000 \mathrm{lpm}$ & Verde
\end{tabular}

Quadro 5 - Identificação dos hidrantes.

Fonte: adaptado de Manual (1997a)

\subsubsection{Comunicação}

De acordo com Manual (1997b) uma comunicação eficiente entre a guarnição e o centro de comunicação do posto de bombeiro é fundamental para o sucesso da operação.

Após receber o chamado para atendimento de uma ocorrência, o centro de comunicações alerta a guarnição e passa as informações sobre a ocorrência. Esta, ao chegar ao local e durante o atendimento repassa para a central a situação e faz solicitações se julgar necessária. Como por exemplo, o envio de outras guarnições, ambulâncias, informações a respeito do local ou sobre a localização de hidrantes próximos para o reabastecimento da viatura.

O corpo de bombeiros utiliza neste caso o rádio como instrumento de comunicação. A comunicação é feita entre as estações e os órgãos de comunicação. 


\begin{tabular}{ll}
\hline Estação fixa & $\begin{array}{l}\text { Equipamento instalado em uma edificação, ligado à energia elétrica. Sua } \\
\text { antena é posicionada em local alto, sendo ideal a instalação em cima de } \\
\text { uma torre. Na falta de energia elétrica, pode ser ligado a uma bateria, que } \\
\text { fornece alimentação até o retorno das condições normais. }\end{array}$ \\
\hline Estação móvel & $\begin{array}{l}\text { Instalada em veículos, obtém energia da bateria do automóvel. } \\
\text { A estação móvel é identificada pelo cadastro operacional da viatura. }\end{array}$ \\
\hline Estação portátil & $\begin{array}{l}\text { Transportável pelo bombeiro, alimenta-se com energia de bateria } \\
\text { recarregável, incorporada ao equipamento. }\end{array}$ \\
\hline Estação repetidora & $\begin{array}{l}\text { É o equipamento que retransmite os sinais recebidos. Destina-se a } \\
\text { aumentar o alcance de uma rede ou operá-la à distância. }\end{array}$ \\
\hline
\end{tabular}

Quadro 6 - Tipos de estações.

Fonte: Manual (1997, v.11).

\subsection{5 Órgãos de Comunicação}

São órgãos destinados a receber solicitação do público e transmiti-las às estações que irão atendê-las.

Os órgãos de comunicação estão estruturados da seguinte forma, segundo o Manual (1997b):

\section{Centro de Operações do Bombeiro (COBOM)}

Órgão instalado junto ao Comando do Corpo de Bombeiros da Capital da cidade de São Paulo. Possui as seguintes responsabilidades:

1. Manter o Comando do Corpo de Bombeiros informado das ocorrências de gravidade no Estado

2. Manter o Comando do Corpo de Bombeiros da Capital informado das ocorrências de gravidade da cidade de São Paulo

3. Confeccionar o resumo diário das ocorrências atendidas no Estado

4. Coordenar e supervisionar as estações de rádio da cidade de São Paulo, de modo a assegurar uma comunicação eficaz

5. Receber as solicitações de emergência e transmiti-las ao sistema de atendimento 
6. Fazer contatos necessários com órgãos federais, estaduais, municipais e particulares para apoio no local de ocorrência.

Centros de Comunicações dos Postos de Bombeiros da Capital

É o órgão responsável pelo recebimento das mensagens do COBOM, enviando para o local sinistrado o material e pessoal designado. Eventualmente, o posto receberá a solicitação direta para atendimento de ocorrência. Neste caso, providenciará o socorro e comunicará o fato ao COBOM.

Centros de Comunicações das Unidades do Interior do Estado

As UOPS (Unidades Operacionais) do interior do Estado possuem centros de comunicações nos municípios onde existem guarnições de bombeiros. Cumprem as mesmas funções do COBOM, estando subordinados ao comandante do respectivo grupamento.

O CCI (Centro de Comunicações do Interior) mantém o COBOM informado das ocorrências de vulto da região, repassando diariamente todos os dados estatísticos. 


\section{Sistemas de Apoio a Decisão}

O presente capítulo tem o objetivo de apresentar os conceitos sobre sistemas de informação e sistemas de apoio a decisão servindo como base para fundamentar a presente pesquisa.

\subsection{O valor da informação}

No ambiente das empresas e organizações, ter ou não ter a informação no momento certo pode significar a sobrevivência da empresa. A informação além de ser precisa deve ser obtida no menor tempo possível.

Dentro do posto de bombeiros, que é objeto desta pesquisa, não deixa de ser diferente. A precisão e a velocidade com que a informação deve ser elaborada e transmitida pode determinar o sucesso ou fracasso de uma operação.

De acordo com Mgee e Prusack (1994), a criação, captação, organização, distribuição, interpretação e comercialização da informação são processos essenciais.

A informação deve ser tratada como qualquer outro bem, mas ela possui algumas características que a diferenciam. Estas, segundo Mgee e Prusack (1994) decorrem do próprio potencial da informação assim como a forma de administrá-la ou gerenciá-la.

A informação é reutilizável, não se deteriora, mas pode sim se depreciar, perdendo seu valor. A informação que chega atrasada, fora de seu tempo pode não ser mais útil. Bem como a informação que fica armazenada e não é utilizada para algum propósito. Neste caso entra o papel do ser humano no uso da informação. 


\subsection{Decisão}

O uso da informação leva o ser humano a tomar decisões. Este diante de um problema pode não ter condições de avaliar todas as alternativas e suas conseqüências, portanto, existe a tendência de simplificar a situação e torná-la administrável (PIDD, 1998).

Sempre que existe mais de uma alternativa para a solução de um problema, surge a necessidade de escolha.

De acordo com Pidd (1998), problemas são construções mentais que emergem do fluxo de questões correntes e para os quais se presta atenção. A formulação do problema depende da interpretação que uma pessoa tem da relação a um assunto. Desta forma uma pessoa pode identificar algo como um problema que outra pessoa poderia ignorar.

\subsection{Processo de tomada de decisão}

A tomada de decisão segundo Marakas (1999) envolve uma série de etapas que vão desde a formulação de um problema até a definição de um modelo para solução do mesmo.

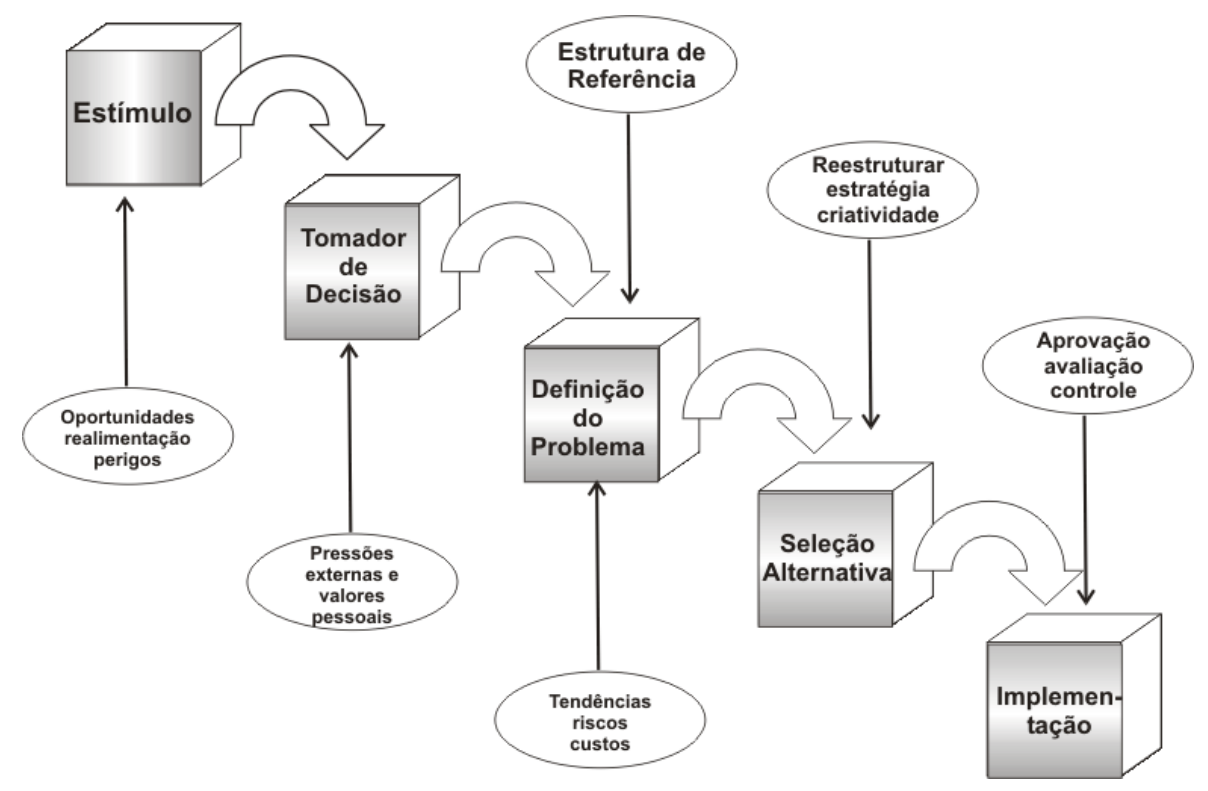

Figura 1 - Exemplo de um processo de tomada de decisão.

Fonte: adaptado de Marakas (1999). 
De acordo com Marakas (1999), uma decisão é raramente criada exatamente na ordem sugerida por um modelo ou mesmo usando todos os passos contidos no modelo. A figura acima procura mostrar como deve ser construída a tomada de decisão.

O estímulo é o primeiro passo no processo, que representa algum evento que faz o decisor perceber que um ou mais problemas existem e requerem uma ou mais decisões.

Marakas (1999) tem a mesma opinião de Pidd (1998) sobre a interpretação dos problemas por parte das pessoas. Este também partilha de idéia de que os problemas surgem da interpretação que as pessoas fazem de um evento e esta interpretação é diferente em cada ser humano.

O decisor da figura acima é uma parte do processo, entretanto ele deve ser tomado como um participante do evento.

A definição do problema para Marakas (1999) é um fator crucial para o processo de tomada de decisão. Se o problema é definido corretamente então o problema terá maiores chances de ser resolvido.

A seleção de alternativas é a fase onde um sistema de suporte à decisão pode vir a ser útil. Estes sistemas podem ser usados para prover uma análise quantitativa de um conjunto de possíveis alternativas e assistir o gerente na escolha de uma melhor solução para o problema.

Selecionada uma alternativa, o processo de decisão desencadeia ações e eventos dentro de uma organização. Estas ações devem ser intensamente planejadas (MARAKAS, 1999).

De acordo com Turban (2001) o processo de tomada de decisão é composto por cinco fases: inteligência, projeto, escolha, implementação e monitoramento. 


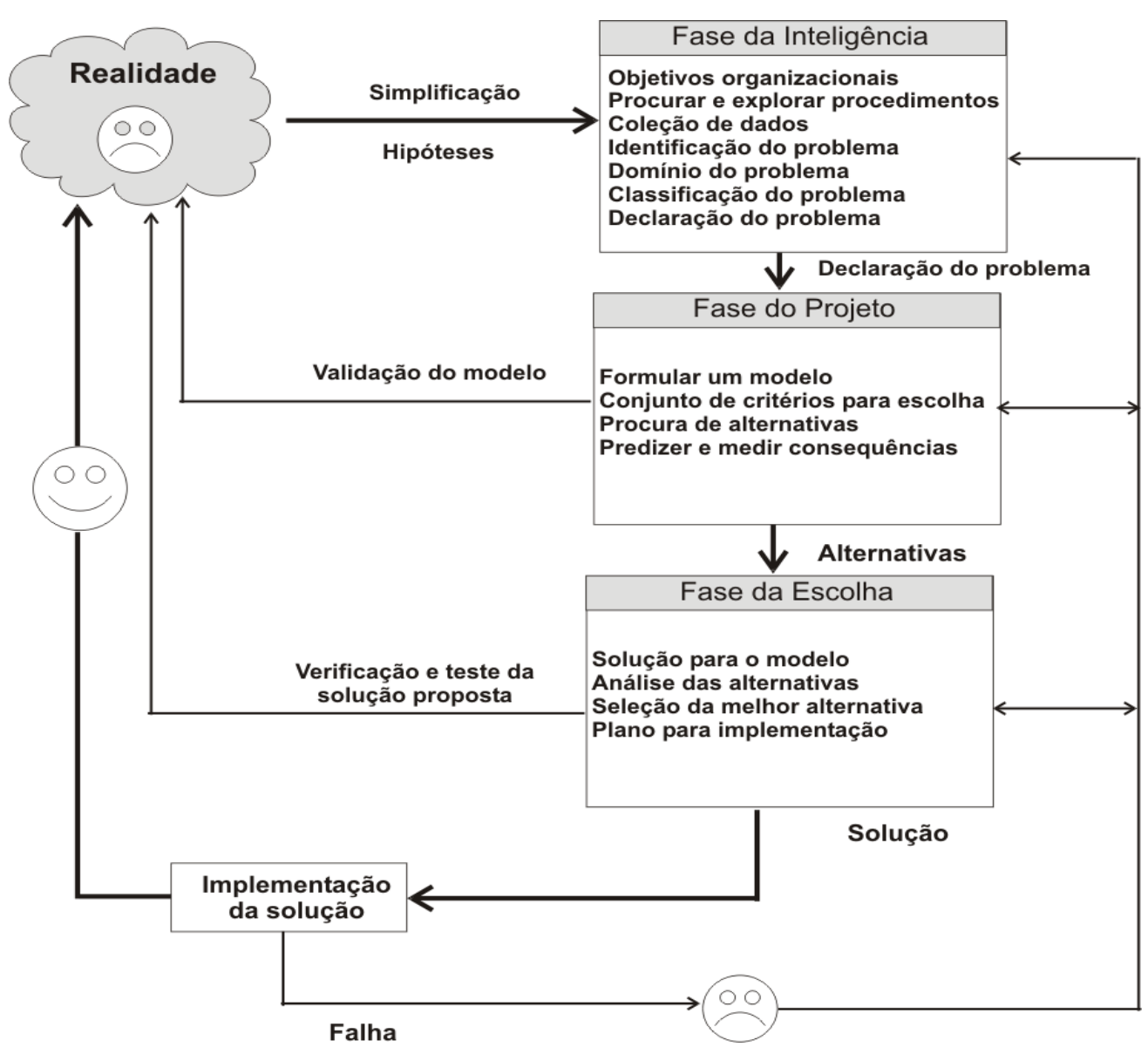

Figura 2 - Modelo de processo de tomada de decisão.

Fonte: Turban (2001).

Turban (2001) dá ênfase à fase de controle e monitoramento que permite dar o retorno (feedback) à fase anterior, o que segundo o autor torna o processo dinâmico e iterativo. De acordo com a figura acima, existe um fluxo contínuo de atividades da fase de inteligência para a fase de projeto e posteriormente para a fase de escolha, mas qualquer fase pode retornar à fase anterior. O processo de tomada de decisão começa com a fase de inteligência onde a realidade é examinada e o problema é identificado e definido. $\mathrm{Na}$ fase de projeto, o modelo que representa o sistema é construído. Isto permite criar suposições para simplificação do problema real. Em seguida o modelo é validado, os critérios são agrupados para avaliação e alternativas e os cursos de ação são identificados. A fase de escolha propõe a seleção de uma solução proposta para o modelo. Esta solução é testada para determinar sua viabilidade. Em seguida vem a fase da implementação que resulta na solução do problema real. 


\subsection{Sistemas de Apoio a Decisão}

Segundo Power (1997) e Shim (2002), Sistemas de Suporte a Decisão são soluções tecnológicas que podem ser usadas para criar decisões complexas e resolver problemas.

Ainda segundo Shim (2002), ferramentas de Sistema de Suporte a Decisão são compostas de:

1. Capacidade de gerenciar sofisticados bancos de dados com acesso a dados internos e externos, informações e conhecimento.

2. Funções de modelagem acessadas por um sistema gerenciador de modelos.

3. Simples, mas poderosa interface que possibilita consultas interativas, relatórios e funções gráficas.

Scott Morton ${ }^{3}$ (1971 apud TURBAN, 2001, p.14) definiu um Sistema de Suporte à Decisão como "um sistema baseado em computador, interativo, que auxilia os tomadores de decisão utilizarem dados e modelos para resolver problemas não estruturados". Desta definição conclui-se que uma característica comum a um Sistema de Suporte à Decisão é a interatividade e facilidade de uso já que tomadores de decisão podem não ter familiaridade com o uso de sistemas informatizados.

A facilidade de uso é favorecida por uma interface mais atraente. A interface, para Shim (2002) é apenas uma das evoluções que estes sistemas tiveram nas ultimas três décadas. Segundo o autor a evolução da computação deve-se à evolução da interface do computador.

Bispo (1998) cita outras evoluções que permitiram o avanço destes sistemas, entre elas a evolução da indústria do computador, o aumento da quantidade de

\footnotetext{
${ }^{3}$ Scott Morton, M (1971). Management Decision Systems: Computer-based Support For Decision Making. Cambridge, MA: Harvard University, Division of Research. Apud TURBAN, E.; ARONSON, J.E. (2001). Decision support systems and intelligent systems. 6thed. New Jersey: Prentice Hall.
} 
informações e no tamanho das informações, a evolução das redes e da internet, o surgimento de gerenciadores de banco de dados e das linguagens de programação de quarta geração. 


\section{Sistemas de Informação Geográfica}

Este capítulo apresenta definições sobre Sistemas de Informação Geográfica e conceitos básicos relacionados a ele.

\subsection{Conceitos básicos}

\subsubsection{Cartografia}

Segundo Meneguette (2001) a Associação Cartográfica Internacional define cartografia como "um conjunto de operações científicas, artísticas e técnicas que, tendo por base os resultados das observações obtidas pelo métodos diretos, indiretos ou subsidiários de levantamento ou exploração de documentos existentes, destinam-se à elaboração e a preparação de mapas e outras formas de expressão, assim como a sua utilização."

\subsubsection{Sistemas de Coordenadas}

Segundo Câmara et al (1996) Um objeto geográfico qualquer (como uma cidade, a foz de um rio, o cume de uma montanha) somente poderá ser localizado se puder ser descrito em relação a outros objetos cujas posições sejam previamente conhecidas, ou se tiver sua localização determinada em uma rede coerente de coordenadas. Quando se dispõe de um sistema de coordenadas fixas, pode-se de unir a localização de qualquer ponto na superfície terrestre.

Os sistemas de coordenadas dividem-se em dois grandes grupos: sistemas de coordenadas geográficas ou terrestres e sistemas de coordenadas planas ou cartesianas.

No sistema de coordenadas geográficas ou terrestres, cada ponto da superfície terrestre é localizado no cruzamento de um meridiano com um paralelo. 
Meridianos são círculos máximos da esfera cujos planos contêm o eixo dos pólos. Paralelos são círculos da esfera cujos planos são perpendiculares ao eixo dos pólos. O Equador é o paralelo que divide a Terra em dois hemisférios: Norte e Sul. Todos os meridianos se encontram em ambos os pólos e cruzam o equador em ângulo reto. A distância entre meridianos diminui do Equador para os pólos. Os paralelos jamais se cruzam.

Representa-se um ponto na superfície terrestre por um valor de latitude e longitude. Longitude é a distância angular entre um ponto qualquer da superfície terrestre e o meridiano de origem. Latitude é a distância angular entre um ponto qualquer da superfície terrestre e a linha do Equador.

Como o sistema de coordenadas geográficas considera desvios angulares a partir do centro da Terra, este para Câmara et al (1996) não é um sistema conveniente para aplicações em que se buscam distâncias ou áreas. Para estes casos, utilizam-se outros sistemas de coordenadas, mais adequados, como, por exemplo, o sistema de coordenadas planas, descrito a seguir.

O sistema de coordenadas planas, também conhecido por sistema de coordenadas cartesianas, baseia-se na escolha de dois eixos perpendiculares, usualmente denominados eixos horizontal e vertical, cuja interseção é denominada origem, estabelecida como base para a localização de qualquer ponto do plano.

Nesse sistema de coordenadas, um ponto é representado por dois números: um correspondente à projeção sobre $\mathrm{o}$ eixo $\mathrm{x}$ (horizontal), associada principalmente à longitude, e outro correspondente à projeção sobre o eixo y (vertical), associada principalmente à latitude. Estas coordenadas são relacionadas matematicamente às coordenadas geográficas, de maneira que possam ser convertidas.

\subsubsection{Mapas e Cartas}

Na definição de Câmara et al (1996) os considera-se que os mapas não têm caráter científico especializado, sendo utilizados para fins ilustrativos ou mesmo comerciais. A carta por sua vez é a representação dos aspectos 
naturais da Terra, destinada a fins práticos da atividade humana, possibilitando determinar direções, localização geográfica de pontos e avaliar distâncias. É comum utilizar-se apenas o termo "mapa" para representar cartas.

Segundo Meneguette (2001), têm-se a planta que é "uma carta regular representando uma superfície de extensão suficientemente restrita para que sua curvatura possa ser desprezada e que, por isso, a escala possa ser considerada como constante".

De acordo com Câmara et al. (1996), a ABNT (Associação Brasileira de Normas e Técnicas), classifica as cartas como:

\begin{tabular}{|c|c|c|c|}
\hline \multicolumn{2}{|r|}{ Geográficas } & \multicolumn{2}{|r|}{ especiais } \\
\hline topográficas & $\begin{array}{l}\text { Confeccionadas mediante } \\
\text { levantamento topográfico regular, } \\
\text { ou compiladas de cartas } \\
\text { topográficas existentes, e que } \\
\text { incluem os acidentes naturais e } \\
\text { artificiais, permitindo facilmente a } \\
\text { determinação de altitudes. }\end{array}$ & meteorológicas & $\begin{array}{l}\text { Mostram as classificações } \\
\text { climáticas e as que, em } \\
\text { serviço contínuo, diário e } \\
\text { sistemático, contêm } \\
\text { informações meteorológicas, } \\
\text { observadas simultaneamente } \\
\text { em vários lugares, além das } \\
\text { alterações progressivas nas } \\
\text { condições do tempo. }\end{array}$ \\
\hline planimétricas & $\begin{array}{lcr}\text { Semelhantes } & \text { às } & \text { cartas } \\
\text { topográficas, } & \text { porém } & \text { não } \\
\text { apresentam indicação de altitudes. }\end{array}$ & de solo & $\begin{array}{l}\text { Identificam e classificam os } \\
\text { diversos tipos de solos e sua } \\
\text { distribuição geográfica. }\end{array}$ \\
\hline $\begin{array}{ll}\text { cadastrais } & \text { e } \\
\text { plantas } & \end{array}$ & $\begin{array}{l}\text { Geralmente em escala } \\
\text { usadas para mostrar } \\
\text { verdadeiros } \\
\text { veropriedades. }\end{array}$ & de vegetação & $\begin{array}{l}\text { Representam as } \\
\text { características e a distribuição } \\
\text { da cobertura vegetal. }\end{array}$ \\
\hline aeronáuticas & $\begin{array}{l}\text { Representam a superfície da } \\
\text { Terra com sua cultura e relevo de } \\
\text { maneira a satisfazer } \\
\text { especificamente as necessidades } \\
\text { da navegação aérea. }\end{array}$ & de uso da Terra & $\begin{array}{l}\text { Representam a classificação e } \\
\text { distribuição geográfica dos } \\
\text { diversos usos aos quais está } \\
\text { sujeita a superfície da Terra. }\end{array}$ \\
\hline Náuticas & $\begin{array}{l}\text { Resultam dos levantamentos dos } \\
\text { mares, rios, canais e lagoas } \\
\text { navegáveis e se destinam à } \\
\text { segurança da navegação. }\end{array}$ & globos: & $\begin{array}{l}\text { Contêm representações da } \\
\text { superfície da Terra em outra } \\
\text { superfície semelhante. }\end{array}$ \\
\hline
\end{tabular}

\section{Quadro 7 - Classificação das cartas cartográficas}

Fonte: Adaptado de Câmara et al. (1996).

\subsubsection{Sensoriamento Remoto}

O sensoriamento remoto é uma tecnologia usada para obter dados para os Sistemas de Informação Geográfica (SIG). De acordo com Câmara et al (1996, p.15), sensoriamento remoto é definido como "um conjunto de processos e 
técnicas usados para medir propriedades eletromagnéticas de uma superfície, ou de um objeto, sem que haja contato entre o objeto e o equipamento sensor".

Existem diversos sistemas de aquisição de dados, tais como câmeras fotográficas aerotransportadas, satélites, sistemas de radar, sonar ou microondas. Os sistemas podem ser ativos, como é o caso dos sistemas de microondas, que registram a diferença de freqüência entre o sinal emitido por elas e o sinal recebido da superfície, ou passivo, como é o caso de câmeras fotográficas, que registram a refletância ou emitância de uma superfície.

\subsubsection{Caracterização de Dados Geográficos}

De Acordo com Câmara et al (1996) o termo "dado espacial" denota qualquer tipo de dados que descreve fenômenos aos quais esteja associada alguma dimensão espacial. Os dados utilizados em SIGs pertencem a uma classe particular de dados espaciais: os dados geo-referenciados ou dados geográficos. $O$ termo denota dados que descrevem fatos, objetos e fenômenos do globo terrestre associados à sua localização sobre a superfície terrestre, num certo instante ou período de tempo.

\section{Características Gerais de Dados Geográficos}

Dados geo-referenciados são comumente caracterizados a partir de três componentes fundamentais (ARONOFF, 1989):

1. Características não-espaciais, descrevendo $\circ$ fenômeno sendo estudado, tais como o nome e o tipo da variável

2. Características espaciais, informando a localização espacial do fenômeno, ou seja, seu geo-referenciamento, associada a propriedades geométricas e topológicas

3. Características temporais, identificando o tempo para o qual tais dados são considerados, isto é, quando foram coletados e sua validade. 


\subsubsection{Geoprocessamento}

Para Câmara et al (2004a) o termo Geoprocessamento denota a disciplina do conhecimento que utiliza técnicas matemáticas e computacionais para 0 tratamento da informação geográfica e que vem influenciando de maneira crescente as áreas de cartografia, análise de recursos Naturais, transportes, comunicações, energia e planejamento urbano e regional. As ferramentas computacionais para Geoprocessamento, chamadas de Sistemas de Informação Geográfica, permitem realizar análises complexas, ao integrar dados de diversas fontes e ao criar bancos de dados geo-referenciados. Tornam ainda possível automatizar a produção de documentos cartográficos.

\subsubsection{Tipos de dados em geoprocessamento}

\subsubsection{Dados temáticos}

Dados temáticos descrevem a distribuição espacial de uma grandeza geográfica, expressa de forma qualitativa, como os mapas de produção agrícola de uma região. A partir destes dados é possível a criação de mapas temáticos.

\subsubsection{Dados cadastrais}

Um dado cadastral distingue-se de um temático, pois cada um de seus elementos é um objeto geográfico, que possui atributos e pode estar associado a várias representações gráficas. Por exemplo, os lotes de uma cidade são elementos do espaço geográfico que possuem atributos (dono, localização, valor venal, IPTU devido, etc.) e que podem ter representações gráficas diferentes em mapas de escalas distintas. Os atributos estão armazenados num sistema gerenciador de banco de dados. A partir de dados cadastrais é possível a criação de mapas cadastrais.

\subsubsection{Redes}

Em Geoprocessamento, o conceito de "rede" denota as informações associadas a: 
1. Serviços de utilidade pública, como água, luz e telefone

2. Redes de drenagem (bacias hidrográficas)

3. Rodovias.

No caso de redes, cada objeto geográfico (cabo telefônico, transformador de rede elétrica, cano de água) possui uma localização geográfica exata e está sempre associado a atributos descritivos presentes no banco de dados.

\subsubsection{Modelos numéricos de terreno}

O termo modelo numérico de terreno (ou MNT) é utilizado para denotar a representação quantitativa de uma grandeza que varia continuamente no espaço.

Comumente associados à altimetria, também podem ser utilizados para modelar unidades geológicas, como teor de minerais, ou propriedades do solo ou subsolo.

\subsubsection{Imagens}

Obtidas por satélites, fotografias aéreas ou "scanners" aerotransportados, as imagens representam formas de captura indireta de informação espacial.

Pela natureza do processo de aquisição de imagens, os objetos geográficos estão contidos na imagem, sendo necessário recorrer a técnicas de fotointerpretação e de classificação para individualizá-los.

Em Geoprocessamento, o espaço geográfico é modelado segundo duas visões complementares: os modelos de campos e objetos (Worboys, 1995 apud Câmara, 2004a) ${ }^{4}$. O modelo de campos enxerga o espaço geográfico como uma superfície contínua, sobre a qual variam os fenômenos a serem observados segundo diferentes distribuições. Por exemplo, um mapa de

\footnotetext{
${ }^{4}$ WORBOYS, M.F. (1995).GIS: A Computing Perspective. London, Taylor and Francis. Apud CÂMARA, G.; DAVIS CLODOVEU, M.A.M. (2004). Introdução à ciência da geoinformação. São José .dos Campos: INPE.
} 
vegetação descreve uma distribuição que associa a cada ponto do mapa um tipo específico de cobertura vegetal, enquanto um mapa geoquímico associa o teor de um mineral a cada ponto.

O modelo de objetos representa o espaço geográfico como uma coleção de entidades distintas e identificáveis. Por exemplo, um cadastro espacial dos lotes de um município identifica cada lote como um dado individual, com atributos que o distinguem dos demais. Igualmente, poder-se-ia pensar como geo-objetos os rios de uma bacia hidrográfica ou os aeroportos de um estado.

\subsubsection{Representação Vetorial e Matricial}

Para Câmara et al (2004a) inicialmente, deve-se considerar as duas grandes classes de representações geométricas: representação vetorial e representação matricial.

$\mathrm{Na}$ representação vetorial, utiliza-se pontos, linhas, áreas e polígonos para representar objetos no mapa da maneira mais exata possível.

A representação matricial consiste no uso de uma malha quadriculada regular sobre a qual se constrói, célula a célula, o elemento que está sendo representado. A cada célula, atribui-se um código referente ao atributo estudado, de tal forma que o computador saiba a que elemento ou objeto pertence determinada célula.

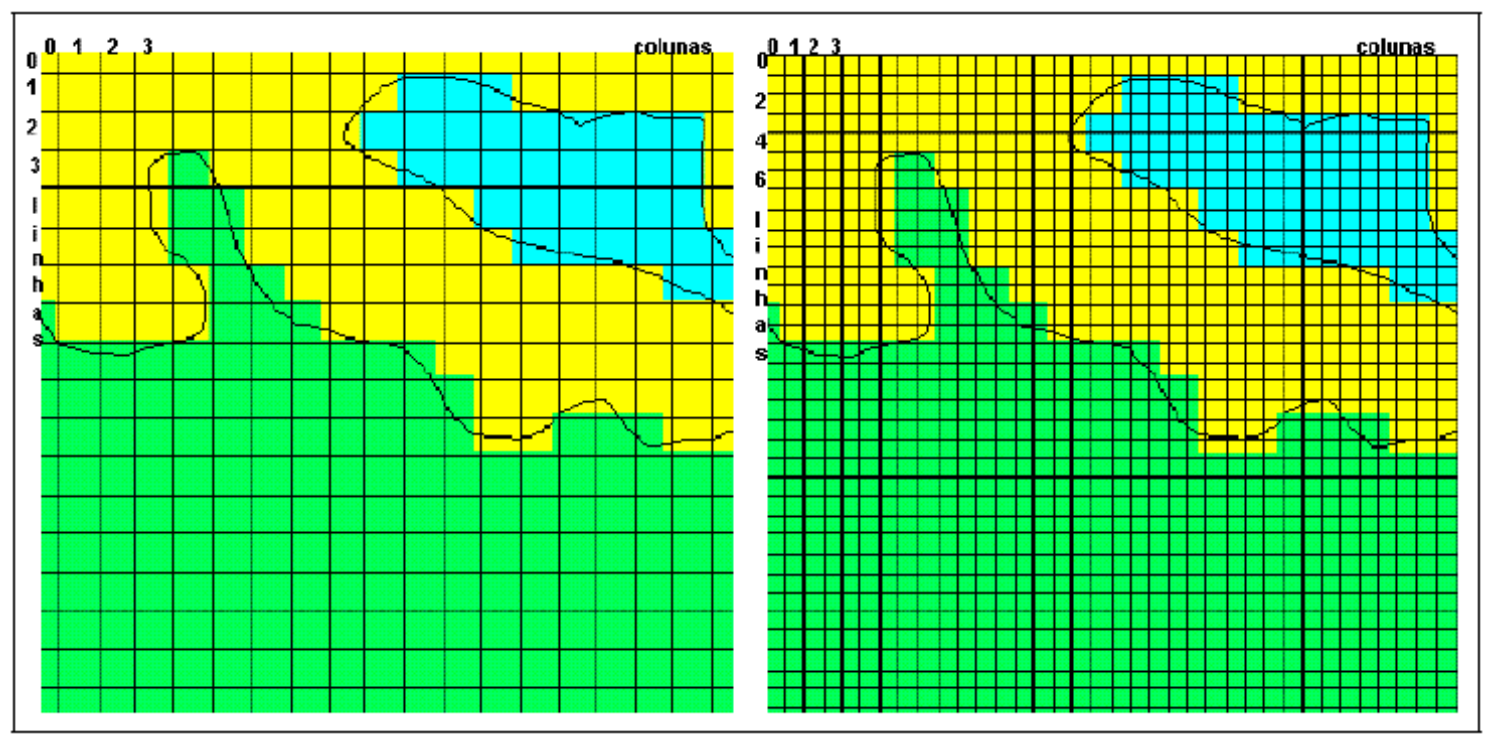

Figura 3 - Diferentes representações matriciais para uma mapa.

Fonte: adaptado de CÂMARA et al. (2004a) 
Vale ressaltar que as representações estão associadas aos tipos de dados anteriormente discutidos, a saber:

1. Dados temáticos: admitem tanto representação matricial quanto vetorial

2. Dados cadastrais: sua parte gráfica é armazenada em forma de coordenadas vetoriais e seus atributos não gráficos são guardados em um banco de dados

3. Redes: sua parte gráfica é armazenada em forma de coordenadas vetoriais, com a topologia arco-nó e seus atributos não gráficos são guardados em um banco de dados

4. Imagens de sensoriamento remoto: armazenadas em representação matricial

5. Modelos numéricos de terreno: podem ser armazenados em grades regulares (representação matricial), grades triangulares (representação vetorial com topologia arco-nó) ou isolinhas (representação vetorial sem topologia).

\subsection{Sistemas de Informação Geográfica (SIG)}

Segundo Huxhold (1991), "um Sistema de Informação Geográfica é uma coleção de informações tecnológicas, dados e procedimentos usados para coletar, armazenar, manipular, analisar e apresentar mapas e informações descritivas sobre objetos que podem ser representados no mapa."

Esta definição cobre uma grande variedade de organizações que usam mapas e informações geográficas para dar suporte as suas atividades. Como resultado, o uso do SIG está se tornando comum em muitas organizações de diversas áreas como pesquisa e mapeamento, transporte, vendas, administração pública.

Uma outra definição vem de Aronoff (1989) onde o SIG é "qualquer conjunto de procedimentos, manual ou automático baseado em computador usado para 
armazenar e manipular dados geograficamente referenciados", isto é, localizados na superfície terrestre e representados numa projeção cartográfica.

Para Maguire et al (1991), em um SIG, a realidade é representada como uma série de características definidas de acordo com dois elementos de dados. Os dados geográficos, também chamados de locacionais são usados para dar referência a um atributo, também chamado de não locacional. Por exemplo, o endereço de uma rua pode ser usada para referenciar um determinado imóvel que está situado nela. Em um SIG o elemento geográfico é visto como mais importante que outros elementos, sendo uma característica que o diferencia de outros sistemas.

\subsection{Diferenças entre o termo espacial e geográfico}

Para Maguire et al (1991), os termos espacial e geográfico são usados frequentemente para descrever atributos geográficos. $O$ termo espacial referese a qualquer tipo de informação a respeito de localização e pode incluir sensoriamento remoto como também informação cartográfica. Por outro lado, geográfico refere-se somente à informação locacional a respeito da superfície da Terra em escalas do mundo real.

\subsection{As três visões de um SIG}

Segundo Maguire et al (1991) as três visões de um SIG são: banco de dados, mapa e análise espacial.

A visão do mapa foca os aspectos cartográficos do SIG. Sua função é a de processar mapas que apresentam um conjunto de dados separados em camadas ou temas. Os mapas são normalmente manipulados por rotinas que podem adicionar e subtrair informações além de realizar consultas e procurar padrões. A saída destas operações é outro mapa.

A visão de banco de dados do SIG enfatiza o uso de um bem projetado e implementado banco de dados que permita consultar e recuperar informações. 
A terceira visão do SIG enfatiza a importância da análise espacial. O objetivo da análise espacial é extrair ou questionar informações úteis que satisfaçam as exigências dos objetivos do usuário para tomada de decisão.

Segundo Câmara et al (2004b), a ênfase da análise espacial é mensurar propriedades e relacionamentos, levando em conta a localização espacial do fenômeno em estudo. Ou seja, a idéia central é incorporar o espaço à análise que se deseja fazer.

Desta forma o SIG permite apresentar um mapa com pontos em destaque ou áreas coloridas permitindo a visualização do padrão espacial do fenômeno.

O exemplo abaixo ilustra a análise espacial feita em um mapa:

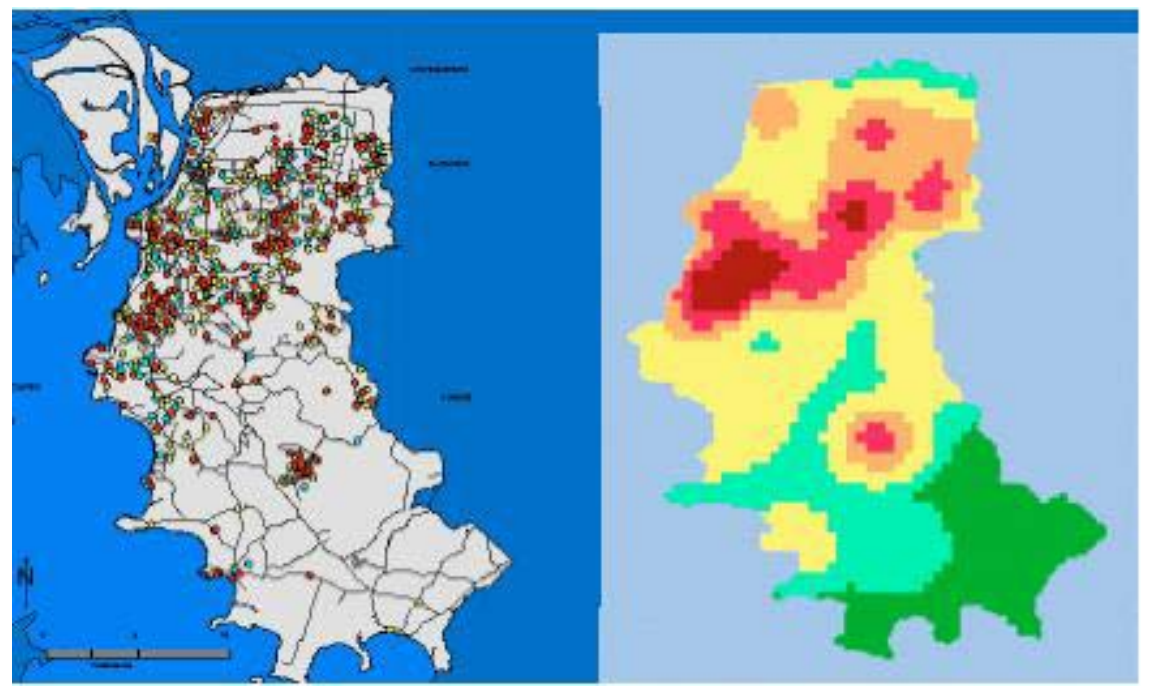

Figura 4 - Distribuição de casos de mortalidade em Porto Alegre.

Fonte: Adaptado de CÂMARA et al. (2004 b).

Como exemplo, a figura acima ilustra a análise espacial para o caso de mortalidade por causas externas em Porto Alegre com os dados de 1996. A localização de homicídios (vermelho), acidentes de trânsito (amarelo) e suicídio (azul) é apresentado à esquerda. À direita, é apresentada uma superfície para a intensidade estimada.

Para Huxhold (1991) todas estas visões podem ser consumadas por um conjunto de ferramentas de SIG que podem ser usadas para automatizar procedimentos, sumarizar dados e prover novas técnicas para analisar dados. Estas ferramentas podem incluir: 
1. Tecnologia de mapeamento automático: provê flexibilidade na manipulação de informações no mapa

2. Gerenciamento de banco de dados: provê flexibilidade no gerenciamento de atributos de dados

3. Informações de registro de terra: oferece dados cartográficos e de atributos necessários para um SIG gravar precisa e completamente mapas e localizações relacionadas ao atributo de dados

4. Estrutura de dados topológicos: oferece recursos de relacionamentos espaciais entre pontos, linhas e polígonos

5. Capacidade de análise espacial: provê a capacidade para recuperar, armazenar, manipular e exibir mapas e localizações relacionados aos atributos de dados.

\subsection{Os elementos de um Sistema de Informação Geográfica}

De acordo com Maguire et al (1991) um SIG é composto de 4 elementos básicos: hardware, software, dados e pessoas.

O hardware pode ser qualquer tipo de computador, incluindo desde computadores pessoais até computadores de grande porte. Isso depende sempre do tipo de aplicação a ser utilizada, ou seja, o software. Muitos deles estão em um nível sofisticado de desenvolvimento. Grandes pacotes de software possuem centenas de comandos e uma grande variedade de funcionalidades.

Para Huxhold (1991) o software para SIG consiste de programas gráficos que podem criar, editar, manipular e apresentar dados cartográficos. Estes programas permitem uma visão da imagem de um mapa, além de criar, editar e manipular linhas, símbolos e textos. Softwares CAD (Computer Aided Design) possuem estas funções, entretanto estes sistemas são normalmente usados em desenhos de engenharia e arquitetura. 
Os dados constituem o terceiro elemento de um SIG. Dados geográficos são muito caros para coletar, armazenar e manipular devido a grandes volumes que são requeridos para resolver problemas geográficos (MAGUIRE et al, 1991).

De acordo com Huxhold (1991) um SIG deve conter informações de um mapa digital armazenado em um banco de dados. Eles podem imprimir ou exibir informação a partir de um banco de dados para produzir um mapa.

Salienta-se a importância dos atributos de dados que são informações descritivas armazenadas em um banco de dados a respeito das características representadas em um mapa. Usualmente estas características são objetos físicos que podem ser vistos (como um edifício ou rua). Algumas vezes estas características não podem ser vistas embora elas possam ser localizadas (como uma parcela de terra). Atributos de dados podem ser processados em um SIG para representar fenômenos como por exemplo, a localização de um crime ou acidente de trânsito.

A estrutura lógica destes dados requer uma referência espacial, ou atributo de localização armazenado em um registro de um banco de dados. Este deve ter uma referência espacial que pode ser uma coordenada geográfica ou ainda uma referência locacional como um endereço ou código postal. Todos estes dados podem ser armazenados em um Sistema Gerenciador de Banco de Dados (SGDB).

Para Silberschatz et al (1999) um SGBD é constituído por um conjunto de dados associados a um conjunto de programas para acesso a esses dados. $\mathrm{O}$ principal objetivo de um SGBD é proporcionar um ambiente tanto conveniente quanto eficiente para recuperação e armazenamento das informações do banco de dados.

De acordo com Câmara et al (2004b), uma organização de banco de dados utilizada é o modelo geo-relacional (ou arquitetura dual), que utiliza um SGBD relacional como o DBase ou o Microsoft Access, para armazenar em suas tabelas os atributos dos objetos geográficos, e arquivos gráficos separados para guardar as representações geométricas destes objetos. 
A principal vantagem do modelo geo-relacional é poder utilizar os SGBDs relacionais de mercado. Do ponto de vista do usuário, esta organização permite que aplicações convencionais, concebidas e desenvolvidas dentro do ambiente de SGBD relacional, compartilhem os atributos dos objetos gráficos.

O quarto elemento do SIG são as pessoas responsáveis pelo projeto, implementação e uso do sistema. Para Maguire et al (1991), somente um pessoal comprometido e treinado pode concluir com êxito um projeto por menor que ele seja. A importância das pessoas dentro de um SIG é muitas vezes deixada de lado para se dar maior foco na tecnologia.

\subsection{Utilizando o SIG}

Considerando a natureza atividades dentro de uma organização poderíamos dizer que existem os SIG do nível organizacional (tarefas do dia-a-dia), gerencial (decisões de caráter tático) e os do nível estratégico (atividades que contribuem diretamente para o cumprimento dos objetivos fundamentais da organização) (FERRARI, 1997, p.22).

\subsubsection{Uso de SIGs no nível operacional}

Para Ferrari (1997), as atividades do nível operacional são aquelas do dia a dia da organização. Além de rotineiras, geralmente as operações são volumosas e trabalhosas. Exemplos desse tipo de atividades: a compensação de cheques em um banco; acompanhamento de uma linha de montagem em uma indústria; processamento de requisições de clientes; manutenção rotineira de prédios e equipamentos; etc

Assim como na automação de uma linha de montagem, o benefício imediato do uso de SIGs no suporte a atividades do nível operacional é a eficiência operacional, ou seja, a execução das atividades que já vêm sendo executadas manualmente (sem apoio de SIGs), só que de maneira mais eficiente: gastando menos recursos. 


\begin{tabular}{|c|c|c|}
\hline Benefícios & O papel do SIG & Exemplos de usos \\
\hline $\begin{array}{l}\text { - Ganho de produtividade } \\
\text { - Redução ou eliminação } \\
\text { de custos ou riscos } \\
\text { - Qualidade na execução } \\
\text { de tarefas }\end{array}$ & $\begin{array}{l}\text { - } \text { Automatização de tarefas } \\
\text { trabalhosas e rotineiras } \\
\text { - Proporcionar maior } \\
\text { qualidade e agilidade no } \\
\text { armazenamento de } \\
\text { informações essenciais } \\
\text { para a execução de tarefas } \\
\text { - Suporte ao planejamento, } \\
\text { monitoramento, } \\
\text { racionalização do trabalho } \\
\text { - Suporte à visualização de } \\
\text { informações } \\
\text { comunicação no trabalho }\end{array}$ & $\begin{array}{l}\text { - Manutenção de mapas ou } \\
\text { outras informações } \\
\text { geográficas } \\
\text { - Geração de mapas e outras } \\
\text { informações para suporte a } \\
\text { projetos de engenharia } \\
\text { - Suporte ao gerenciamento de } \\
\text { redes de infra-estrutura: } \\
\text { planejamento de manutenção } \\
\text { preventiva, planejamento e } \\
\text { monitoramento de tarefas, } \\
\text { geração de esquemas de } \\
\text { trabalho, suporte a situações } \\
\text { de emergência, etc. } \\
\text { Otimização de rotas de coleta } \\
\text { ou distribuicão }\end{array}$ \\
\hline
\end{tabular}

Quadro 8 - Usos e benefícios de SIGs no nível operacional

Fonte: Adaptado de Ferrari (1997, p.23)

\subsubsection{Uso de SIGs no nível gerencial}

Decisões de caráter tático são atividades típicas do nível gerencial. Qual a melhor localização para uma nova filial? Uma questão semelhante no setor governamental seria: qual a região mais carente de um determinado serviço público?

A tabela abaixo, aponta o papel do SIG no nível gerencial: manipulação, análise, integração, e visualização de informações. O SIG não toma decisões. Mas o uso de um SIG como uma ferramenta de trabalho facilita a obtenção de boas decisões. 


\begin{tabular}{|c|c|c|}
\hline Benefícios & O papel do SIG & Exemplos de usos \\
\hline $\begin{array}{l}\text { - Melhores (ou novas) } \\
\text { informações } \\
\text { - Melhores decisões de } \\
\text { caráter tático: } \\
\text { planejamento, } \\
\text { gerenciamento, alocação } \\
\text { de recursos }\end{array}$ & $\begin{array}{l}\text { - Proporcionar agilidade na } \\
\text { geração de informações } \\
\text { para suporte a processos } \\
\text { intelectuais: decisões, } \\
\text { planejamento, } \\
\text { monitoramento } \\
\text { - Prover maior capacidade } \\
\text { de manipulação de } \\
\text { informações: modelagem, } \\
\text { espacial, } \\
\text { simulações } \\
\text { - Mecanismo para integrar, } \\
\text { visualizar e resumir } \\
\text { informações complexas e } \\
\text { diversas; mecanismo de } \\
\text { comunicação }\end{array}$ & 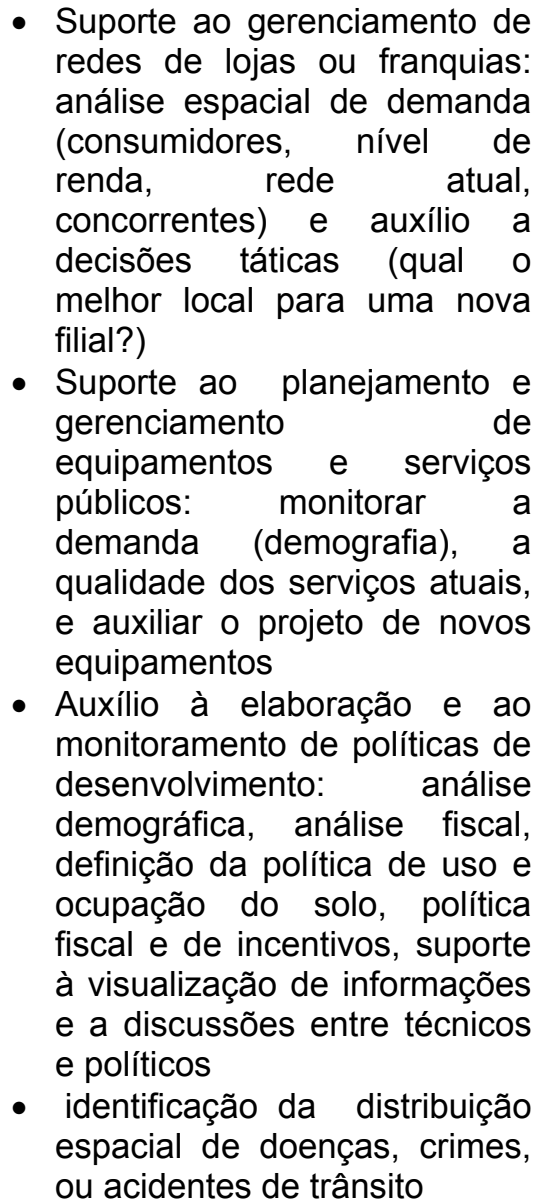 \\
\hline
\end{tabular}

Quadro 9 - Usos e benefícios de SIGs no nível gerencial

Fonte: Adaptado de Ferrari (1997, p.25)

\subsubsection{Uso de SIGs no nível estratégico}

As atividades do nível estratégico são aquelas que contribuem diretamente para o cumprimento dos objetivos fundamentais da organização (FERRARI, 1997). Exemplos de objetivos estratégicos são: aumentar a satisfação dos clientes, melhorar a imagem da empresa junto a (potenciais) clientes $e$ parceiros, aumentar a margem de lucro, aumentar a participação da empresa nos segmentos de mercado em que atua, expandir a participação da empresa a outros segmentos, etc. 


\begin{tabular}{|c|c|}
\hline Benefícios & Exemplos de usos \\
\hline $\begin{array}{l}\text { - Melhor imagem junto } \\
\text { a clientes e parceiros } \\
\text { - Compartilhamento de } \\
\text { custos } \\
\text { - Novas fontes de } \\
\text { receita, aumento de } \\
\text { receita. }\end{array}$ & $\begin{array}{l}\text { - Uso de Sigs em projetos para solução de problemas estratégicos. } \\
\text { - Uso de Sigs em projetos sociais para melhorar os serviços à } \\
\text { população, a satisfação da população. } \\
\text { - Mapeamento e apoio ao gerenciamento da satisfação e das } \\
\text { necessidades dos eleitores; suporte a ações de marketing político. } \\
\text { - Compartilhamento de bases de dados e de custos operacionais } \\
\text { entre prefeitura, concessionárias, e outras instituições. } \\
\text { - Fornecimento de uma boa infraestrutura de informações } \\
\text { espaciais ou serviços a setores da indústria ou a outros órgãos } \\
\text { de administração pública } \\
\text { - Venda de dados; mapeamento e gerenciamento da arrecadação } \\
\text { de impostos. }\end{array}$ \\
\hline
\end{tabular}

Quadro 10 - Usos e benefícios de SIGs no nível estratégico

Fonte: Adaptado de Ferrari (1997)

\subsubsection{O uso de SIGs na sociedade}

Para Ferrari (1997) quando a administração pública é eficaz, a própria sociedade é indiretamente beneficiada. Por exemplo, coerência na alocação de recursos públicos gera, com o tempo, melhores serviços à população. A tabela abaixo apresenta alguns exemplos de uso de um SIG neste tipo de projeto.

\begin{tabular}{|c|c|c|}
\hline Benefícios & O papel do SIG & Exemplos de usos \\
\hline $\begin{array}{l}\text { - Melhores serviços ou } \\
\text { serviços adicionais à } \\
\text { população } \\
\text { - Melhor qualidade de vida }\end{array}$ & $\begin{array}{l}\text { - Prover maior agilidade no } \\
\text { acesso às informações } \\
\text { - Suporte ao diagnóstico e } \\
\text { ao monitoramento de } \\
\text { problemas } \\
\text { - Mecanismo mais adequado } \\
\text { para visualização de } \\
\text { informações e para } \\
\text { comunicação com leigos }\end{array}$ & $\begin{array}{l}\text { - Agilização do atendimento, } \\
\text { consultas por telefone, acesso } \\
\text { a informações através de } \\
\text { terminais públicos de consulta } \\
\text { - Projetos para melhoria da } \\
\text { qualidade de vida, combate à } \\
\text { pobreza, à criminalidade, à } \\
\text { mortalidade infantil } \\
\text { - Maior agilidade nas ações que } \\
\text { levam risco à população }\end{array}$ \\
\hline
\end{tabular}

Quadro 11 - Exemplo de uso do SIG em benefício direto da sociedade

Fonte: Adaptado de Ferrari (1997) 


\section{Metodologias de implantação de um SIG}

Como citado no capítulo 1, o presente projeto de pesquisa tem como objetivo estudar a implantação de uma ferramenta SIG dentro do posto de bombeiros e descrever como foi este processo, relatando aspectos positivos e negativos. $O$ presente capítulo relata as metodologias de desenvolvimento, implantação e treinamento.

Como citado anteriormente, os bombeiros em geral têm dificuldade em encontrar um ponto para abastecimento de suas viaturas quando estão atendendo a uma ocorrência de incêndio.

A escolha por um ponto de abastecimento da viatura sofre a influência de algumas variáveis como: a quantidade de água ou vazão de água do local, a distância do local da ocorrência, facilidade de acesso, fluxo de trânsito, e quantidade de viaturas envolvidas no atendimento. Todas estas variáveis combinadas tornam difícil a tomada de decisão de forma a escolher o melhor ponto para o abastecimento.

A necessidade de um sistema para auxiliar a solução deste problema foi constatada durante as primeiras visitas feitas ao posto de bombeiros do município de Rio Claro, SP.

Estas primeiras visitas foram importantes para determinar as necessidades que este sistema deveria atender.

Diante do panorama exposto optou-se por criar um Sistema de Informação Geográfica constituído de:

1. Um mapa em formato digital, que foi obtido junto à Prefeitura Municipal de Rio Claro 
2. Um programa para manipulação deste mapa e criação dos pontos de abastecimento

3. Um banco de dados para armazenamento das informações a respeito dos pontos de abastecimento.

A implantação da ferramenta SIG neste projeto procurou fundamentar-se em metodologias disponíveis na bibliografia consultada.

Entre as metodologias pesquisadas estão as de Huxhold (1995) e Clarke (1991), sendo que está ultima foi a que melhor se enquadrou dentro dos propósitos do projeto.

A metodologia de Huxhold(1995) está aqui relatada, pois alguns pontos foram considerados durante a implantação do presente projeto.

\subsection{Modelo de implantação segundo Huxhold (1995)}

Huxhold (1995), aponta os seguintes estágios para a implementação de um SIG.

1. Plano de implementação

2. Desenvolvimento de uma visão conceitual

3. Plano de partida

4. Plano estratégico

5. Projeto geral

\subsubsection{Plano de implementação}

Para Huxhold (1995), as seguintes tarefas devem ser acompanhadas durante a implementação.

1. Análise das necessidades: consiste em avaliar as necessidades, determinar o trabalho de várias unidades de negócio, determinar quais são as informações necessárias e avaliar como o SIG pode ser avaliado para o trabalho. 
2. Projeto do sistema: determinar os processos, dados e tecnologia requerida para suportar as necessidades definidas para cada aplicação de SIG identificada.

3. Especificação do projeto: $O$ projeto de requisitos através da análise e design dos processos pode ser traduzido em especificações técnicas para serem usados para estruturar banco de dados, selecionar software, escrever programas customizados, selecionar e configurar hardware.

4. Instalação do hardware e do software: consiste em selecionar o hardware e software adequado para o sistema.

5. Conversão de dados: dados para suportar as aplicações identificadas podem ser obtidos de outros formatos digitais.

6. Treinamento: o pessoal que irá usar o sistema deve ser treinado para operá-lo.

O propósito do plano de implementação é oferecer um gerenciamento da estrutura de trabalho na qual a implementação irá ocorrer para assegurar a devida eficiência e custo.

Este plano consiste em uma série de passos. O número de passos e sua complexidade dependem do escopo do sistema. Entretanto, cada implementação de um SIG requer um plano e em cada plano os seguintes assuntos devem ser tratados:

1. Planejamento do processo de implantação: organizar as tarefas associadas com a implementação e suavemente criar a transição de um plano estratégico para a implementação em SIG.

2. Criar uma arquitetura de gerenciamento da implantação: Designar papéis e responsabilidades para os participantes do projeto. 
3. Desenvolver uma visão conceitual: articular os conceitos, prevendo durante o planejamento estratégico como um conjunto de partes pequenas pode ser analisado, especificado e implementado.

4. Gerenciar expectativas, estabelecer prioridades e uma seqüência apropriada de eventos. Comunicar os requisitos para implementação do projeto aos participantes em detalhes suficientes para todos entenderem o que deve ser feito, quanto tempo irá levar, quanto irá custar e quem precisará estar envolvido ao longo do tempo.

5. Estabelecer metas e prazos.

6. Desenvolver especificações "livres de erros". Estruturar e planejar o sistema para que ele produza o menor número de erros.

\subsubsection{Desenvolvendo uma visão conceitual}

Com a estrutura de implementação estabelecida, a implementação das tarefas pôde continuar. Através de apresentações e discussões os participantes irão compreender o que será feito e como será feito.

Algumas técnicas podem ser usadas para facilitar a visão conceitual do processo. Elas consistem em mostrar os benefícios do SIG através de apresentação de seminários exibição de produtos e visita a empresas.

Nesta visão conceitual também devem ser relatadas:

1. A organização física existente

2. As funções do negócio e as decisões que serão tomadas

3. As informações que a organização irá usar

4. A tecnologia que será empregada para manipular dados e informações. 


\subsubsection{Preparando um plano de implementação}

Documentar um plano de implementação pode ser visto como uma tarefa onerosa e que frequentemente não é feita de uma maneira rápida. Entretanto, um plano bem documentado é talvez o melhor investimento de tempo na implementação de um SIG pelas seguintes razões:

1. Desenvolver um plano de implementação detalhado força a consideração de muitos problemas antes que eles cheguem, assegurando consenso na ação e avaliando a necessidade de recursos.

2. O plano cria um agendamento de trabalho, especialmente importante em projetos multiparticipativos.

3. Um plano bem desenvolvido e o agendamento de tarefas asseguram que todos os participantes do projeto são conscientes do seu papel.

4. Atividades podem ser realizadas concorrentemente, quando apropriadas permitindo um rápido ritmo de desenvolvimento sem aumento de riscos.

\subsubsection{Plano de partida}

Nesta etapa, os participantes devem ser definidos e organizados em equipes com uma comissão encarregada de implementar as tarefas. A arquitetura de implementação, a visão conceitual e a implementação do plano de processo devem ser apresentados no que Huxhold (1995) chama de plano de partida.

O propósito do plano de partida é criar uma ponte de transição entre o plano estratégico, durante o qual, segundo Huxhold (1995), tudo é abstrato e distante no futuro e o plano de implementação durante o qual são tratados problemas concretos.

O plano de partida também pode identificar qualquer problema pendente que não foi resolvido durante o processo de planejamento. $O$ plano de partida pode renovar o processo de implementação do SIG. 
Para Huxhold (1995), o plano de partida economiza tempo, pois o planejamento possibilita realizar as tarefas com mais segurança e evita o retrabalho.

Os participantes também irão saber em que parte da implementação eles se encaixam e o que se espera que eles façam. Gerentes médios irão precisar alocar tempo para análise e projeto das atividades em adição às responsabilidades normais de seu posto.

Abaixo uma lista das principais características do plano de partida:

1. O propósito do plano de partida é prover um plano de trabalho temporário e um cronograma enquanto a implementação está sendo organizada.

2. O plano apresenta toda a seqüência de eventos e tarefas necessárias para realizar a implementação.

3. O plano de partida procura criar uma curta declaração da visão estratégica e indica também quando o projeto será iniciado.

4. Declaração do escopo e objetivos do sistema.

5. Definição de quem irá preparar o plano e implementá-lo.

6. Descrição de todas as tarefas da implementação.

7. Criação de um cronograma de todas as tarefas, com datas de inicio e fim.

8. Criação de um gráfico de Gantt para mostrar o relacionamento entre as tarefas e as datas de execução destas tarefas.

9. Declaração do orçamento previsto para o sistema.

\subsubsection{Projeto geral}

Para Huxhold (1995), deve ser criado também um projeto geral, que é a tradução das necessidades do usuário analisadas para a descrição dos 
componentes do sistema. O projeto geral é um modelo conceitual de SIG a partir da perspectiva de fluxo e uso da informação. Quando a visão conceitual foi criada, algumas idéias gerais foram desenvolvidas de como o SIG deve ser usado.

Após o projeto geral ter sido completado, mais informações sobre a organização serão obtidas. Com isto é possível estimar melhor os custos e determinar o tempo da implementação. Esta é uma boa prática para repensar a viabilidade e assegurar que os recursos e tempo alocados para a implementação são realísticos.

Tendo confirmado o projeto geral (design geral) e selecionado uma aplicação entre várias analisadas, uma seqüência deve ser seguida.

Aplicações que irão criar dados de outras aplicações (por exemplo: a criação de um mapa base para subseqüentes temas de informação) devem ser implementados primeiro. Por isso é melhor começar com uma simples aplicação enquanto o pessoal está aprendendo e os erros estão sendo corrigidos. Nesta etapa Huxhold (1995) defende o uso do projeto piloto, ou seja, uma aplicação para testes.

Cada aplicação do SIG deve ser trabalhada em detalhe. Projeto detalhado consiste em descrever as especificações funcionais e a arquitetura do sistema com o objetivo de descrever o que o sistema irá fazer dentro das descrições técnicas específicas e de como o sistema irá realizar as funções requeridas de cada aplicação selecionada.

A quantidade de trabalho compreende em grande medida na abordagem usada no projeto geral. Se um rigoroso estudo foi realizado, então o projeto irá principalmente consistir da extração e refinamento das especificações relevantes para a aplicação específica. Se o projeto geral deve requerer a análise de dados (como estes serão manipulados e analisados) e processos, especificando como a aplicação irá se encaixar dentro do fluxo de trabalho do usuário. 
Gerenciamento da estrutura de trabalho é um termo usado para descrever a estrutura organizacional na qual a implementação irá ocorrer. Isto consiste em uma hierarquia de comunicação e tomada de decisão que irá garantir implementações participativas, eficientes e úteis para a organização.

As decisões podem ser encaixadas nas seguintes categorias:

1. Políticas, relacionadas aos orçamentos e decisões estratégicas

2. Gerenciamento da implementação

3. Seleção da tecnologia

4. Implementação de técnicas alternativas

Os participantes podem ser categorizados em:

1. Responsáveis: gerentes e supervisores

2. Usuários finais: as pessoas que irão operar o sistema

3. Gerentes de Projeto: que serão responsáveis pelo planejamento e implementação do sistema

4. Projetistas do sistema: que irão determinar as necessidades dos usuários finais e transportá-las para o sistema

5. Provedores de dados: que podem incluir usuários finais do sistema, sistemas computadorizados já existentes, outras empresas, etc..

O sucesso na tomada de decisão durante o plano de implementação é alcançado através de uma apropriada combinação de estruturas, participantes e seus respectivos papéis. A hierarquia de estruturas e papeis irão ajudar a assegurar as melhores decisões a serem realizadas em todos os níveis de planejamento.

O quadro abaixo mostra como deve ser implementado um Sistema de Informação Geográfica segundo Huxhold (1995). 


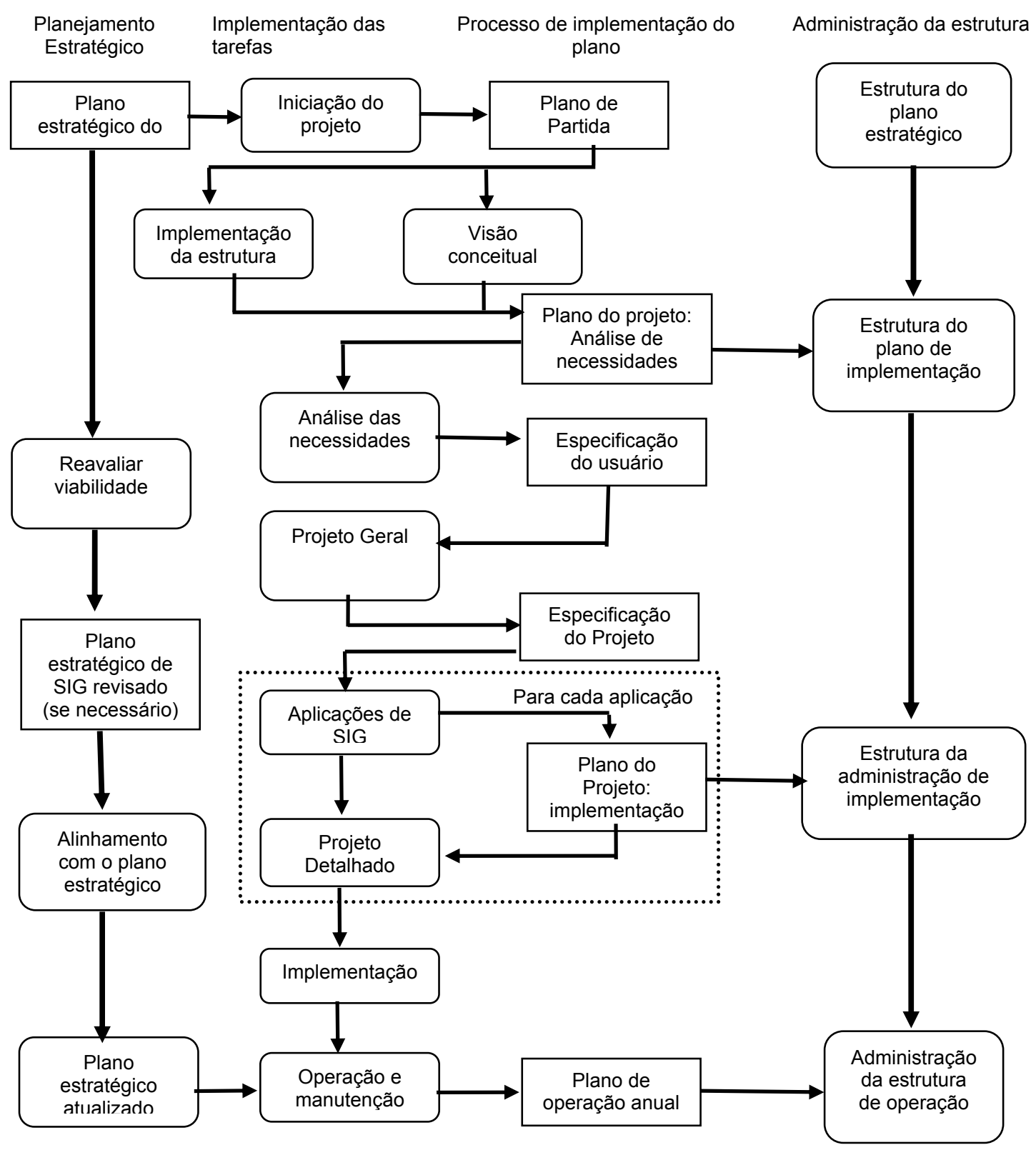

Figura 4 - Sistema de informação geográfica.

Fonte - HUXHOLD, W.E.; LEVINSHON, A.G. (1995); Managind geographic information projects. Oxford. University Press. NY. USA. 


\subsection{Modelo de implantação segundo Clarke (1991)}

Clarke (1991), apresenta um modelo de implantação de SIG composto de 4 estágios:

\begin{tabular}{|c|c|}
\hline Estágio & Passos \\
\hline \multirow{5}{*}{1 - Análise de requisitos } & 1 - Definição dos objetivos \\
\hline & 2 - Análise dos requisitos do usuário \\
\hline & 3 - Projeto preliminar \\
\hline & 4 - Análise de custo e benefício \\
\hline & $5-$ Estudo piloto \\
\hline \multirow{2}{*}{2 - Especificação dos requisitos } & 6 - Projeto final \\
\hline & 7 - Requerimento de propostas \\
\hline \multirow{3}{*}{3 - Avaliação das alternativas } & $8-$ Shortlisting \\
\hline & 9 - Teste de performance \\
\hline & 10 - Avaliação da eficácia financeira \\
\hline \multirow{4}{*}{4 - Implementação do sistema } & 11 - Plano de implementação \\
\hline & 12 - Contrato \\
\hline & 13 - Teste de aceitação \\
\hline & 14 - Implementação \\
\hline
\end{tabular}

Quadro 12 - Modelo de implementação de um SIG

Fonte: adaptado de CLARKE (1991)

Alguns destes passos não se encaixam na proposta do projeto, já que são etapas voltadas para a área comercial. Clarke (1991) mostra como proceder na escolha de um SIG para uma empresa. Desta forma o passo 12 referente ao contrato não foi levado em consideração. Esta metodologia, no entanto se mostra adequada ao projeto em outros aspectos orientando em estágios como a definição de requisitos e estudo piloto.

Algumas considerações são feitas com relação à metodologia de Clarke (1991):

\subsubsection{Estágio 1: Análise de requisitos}

Este estágio é um processo iterativo de identificação e refinamento de requisitos.

Passo 1: Definição dos objetivos e análise de requisitos: o primeiro passo compreende a definição do objetivo e a obtenção de suporte dos dirigentes e usuários. 
A aquisição de um SIG deve ser compatível com a missão da organização. Os objetivos devem focar os resultados e devem ser mensuráveis. Aspectos chaves incluem custo, tempo, qualidade, precisão e impacto no pessoal.

Passo 2: Análise de requisitos do usuário.

Os objetivos deste passo são determinar os requisitos do usuário sobre o qual o SIG será projetado e avaliado. A saída de um SIG é uma informação obtida por processamento de dados geográficos. Três níveis de requisitos devem ser então identificados: informação, processamento e dados. As análises das atividades são:

1. Avaliar informação existente, processamento e dados

2. Identificar os usuários do SIG

3. Definir características do sistema

4. Estimar carga de trabalho e desempenho necessário.

A avaliação inicial deve resultar em uma compreensão de quais informações são usadas, quem está usando e como os dados estão sendo coletados, processados e armazenados.

Estas informações podem ser obtidas através de entrevistas, revisão de documentos e grupos de trabalho.

Os usuários de SIG podem incluir: tomadores de decisões, pessoas que irão coletar e manusear os dados e pessoas que irão usar o sistema no dia-a-dia.

A definição de requisitos do sistema é para Clarke (1991), a chave para a análise de requisitos do usuário. Aplicações e capturas de dados podem requerer uma faixa de produtos intermediários para realização de seus objetivos. Essas informações propiciam um ponto de partida para determinar as necessidades do usuário, mas por outro lado podem aumentar o número de potenciais produtos. 
Requisitos de dados são determinados diretamente a partir da definição do produto. As análises devem identificar a classificação, precisão e a freqüência da atualização de cada tipo de dados.

Passo 3: Projeto do sistema.

As informações obtidas durante o passo 2 habilitam um projeto preliminar para o SIG a ser desenvolvido. O projeto será usado para análise de custo-benefício e especificação do estudo piloto. O projeto preliminar permite:

1. Desenvolver especificações preliminares da base de dados

2. Desenvolver especificações preliminares da funcionalidade

3. Desenvolver modelos preliminares do sistema

4. Pesquisar o mercado na procura de sistemas potenciais.

A classificação, precisão e freqüência da atualização foram identificadas durante a analise e requisitos de dados. As especificações preliminares da base de dados também devem identificar a origem, o volume e estruturas de dados espaciais. Devem ser consideradas a escolha de modelos de dados espaciais por vetores ou raster, um modelo relacional completo ou ainda outros modelos de armazenamento de dados.

Modelos conceituais devem ser desenvolvidos e documentados para descrever o projeto lógico e físico do sistema proposto. Aspectos incluem hardware, software, comunicações, processo, pessoas e arranjo organizacional.

Uma pesquisa de mercado deve ser conduzida para determinar as capacidades do sistema através do projeto preliminar. O objetivo é determinar se especificações preliminares podem ser encontradas na tecnologia atual.

Passo 4: Análise de custo e benefício.

A análise de custos e benefícios tem como objetivo:

1. Estimar todos os custos 
2. Identificar todos os benefícios

3. Estimar o valor econômico de benefícios quantificáveis.

4. Estimar impactos na organização e no pessoal

5. Estimar riscos

6. Analisar resultados.

Os custos para implementação e aquisição de um SIG incluem a aquisição e manutenção de hardware e software, captura e manutenção de dados e treinamento e todas as despesas gerais associadas a ele.

Três categorias de benefícios de SIG podem ser definidos:

eficiência, eficácia e benefícios intangíveis.

Eficiência esta relacionada ao tempo e economia de custos diretos e à redução de esforços, enquanto eficácia está relacionada ao aumento no processo de tomada de decisão. Benefícios intangíveis podem incluir um aumento na imagem pública da organização, uma redução na confusão causada por dados contraditórios, aumento da cooperação entre usuários através do compartilhamento de informações, maior habilidade para agir em situações inesperadas, maior conhecimento através da análise de dados.

Com relação ao impacto no pessoal, este pode ser determinado através da análise de requisitos do usuário. Na organização este impacto pode incidir na alteração da estrutura organizacional associada a novas tecnologias, novos papéis e procedimentos.

A análise de custos e benefícios deve incluir uma avaliação dos riscos que o projeto pode não alcançar em termos de tempo, custos, especificações e benefícios. Outros fatores de risco incluem a complexidade dos dados e o sistema que está sendo considerado, a composição e experiência do pessoal envolvido no projeto.

Passo 5: Estudo piloto 
O objetivo principal do estudo piloto é testar o projeto preliminar antes de concluir as especificações do sistema e comprometer maiores recursos.

O segundo objetivo é desenvolver o conhecimento e confiança dos usuários na tecnologia, demonstrando a aplicação com seus dados, e para ganhar alguma experiência para auxiliar os testes de performance do passo nove. As atividades do estudo piloto envolvem:

1. Projeto do estudo piloto

2. Seleção de um sistema piloto

3. Obtenção de dados pilotos

4. Produção de estudos pilotos

5. Análise dos resultados

O documento do projeto de estudo piloto deve incluir o estudo dos objetivos, seleção do sistema piloto, dados e identificar recursos e cronogramas.

O projeto piloto deve incluir todos os tipos de dados possíveis. É necessário selecionar uma pequena área geográfica e colocar todos os dados referentes a ela. O resultado do piloto deve levar ao refinamento do banco de dados e da especificação do sistema, além de rever os custos, benefícios, impactos e riscos.

\subsubsection{Estágio 2: Especificação dos requisitos.}

Neste estágio os requisitos dos usuários são transformados em uma especificação e solicitação de propostas.

Passo 6: Projeto final.

Especificação da funcionalidade, da base de dados e da performance desejada.

As tarefas desta etapa incluem:

1. Finalizar as especificações do banco de dados 
2. Finalizar as especificações funcionais

3. Finalizar as especificações de performance

4. Especificar os limites do sistema, ou seja, o que irá fazer e o que não irá fazer.

5. Especificar os requisitos gerais do sistema.

6. Estas tarefas devem ser realizadas após o teste com os pilotos e devem ser documentados.

Passo 7:Requerimento de proposta

O documento de requerimento de proposta combina o projeto final com 0 requerimento contratual da empresa. Este documento é entregue ao fornecedor. Seu objetivo é:

1. Especificar os requerimentos contratuais.

2. Especificar a avaliação da metodologia.

3. Atualizar o requerimento de proposta.

Este documento determina quem são os responsáveis pela instalação de todas as partes do sistema e do software.

Para Clarke (1991), nesta etapa a preocupação deve ser com relação à qual ferramenta escolher de acordo com as propostas dor fornecedores deste tipo de sistema. Portanto, informações como data para implantação, preço, suporte técnico, detalhes contratuais devem ser observados.

\subsubsection{Estágio 3: Avaliação de alternativas}

Passo 8: Shortlisting

Consiste em verificar requisitos obrigatórios em uma série de sistemas selecionados. Para cada requisito deve ser atribuído um peso numérico. Em seguida o sistema obtém uma pontuação total. 
Passo 9: Teste de performance

O objetivo do teste de performance é determinar estimativas realísticas em termos de carga de trabalho. Este passo também tem como objetivo obter uma uma avaliação informal dos usuários.

Passo 10: Avaliação da eficácia financeira

Consiste em determinar a razão entre benefícios e custos para o sistema.

As atividades desta etapa são:

1. Formular configurações.

2. Analisar custos de cada configuração.

3. Computar taxas de custos efetivas.

4. Analisar resultados.

Configurações são formadas definindo o hardware e software. Algumas características do hardware tais como, volume de armazenamento em disco e o número de estações de trabalho pode ser necessário.

Custos operacionais para essas configurações sobre o tempo de vida do sistema devem ser determinados para no mínimo cinco anos. Os custos totais devem ser determinados para assegurar que a análise de custo-beneficio permanece válida.

\subsubsection{Estágio 4: Implantação do sistema}

Passo 11: Plano de implantação.

Neste plano, devem ser definidas tarefas, prioridades, cronograma, orçamento e um plano de gerenciamento.

Deve-se definir as prioridades de forma que alguns benefícios iniciais possam ser alcançados o quanto antes. 
Entre as tarefas a serem realizadas incluem-se: instalação e testes de aceitabilidade, customização da interface do usuário, treinamento dos operadores, captura dos dados iniciais e desenvolvimento do produto.

Passo 12: Contrato

Este passo refere-se às condições contratuais do sistema de informação geográfica que a empresa está adquirindo

Passo 13: Teste de aceitação

Os testes de aceitação consistem em:

Teste de funcionalidade e performance: estes testes devem ser realizados para assegurar que as especificações do sistema podem ser realizadas abaixo das condições normais do sistema.

Teste de confiabilidade: refere-se a testes de avaliação e recuperação do sistema abaixo das condições normais do sistema.

Passo 14: Implantação

Após todas as etapas anteriores estarem concluídas o sistema está pronto para ser implantado em caráter definitivo.

As atividades desse passo consistem em: treinamentos de usuários e do pessoal de suporte, monitoramento constante da performance e atualização da base de dados do sistema.

\subsection{Aspectos importantes para o sucesso da implantação de um SIG}

Segundo Korte (2001), implantar um SIG requer um grande gasto de tempo e dinheiro. Por esta razão é muito freqüente a necessidade de aprovação da alta gerência dentro da organização. No que diz respeito ao SIG a alta gerência normalmente não tem familiaridade com este tipo de tecnologia. Alguns podem conhecer a respeito de tecnologia básica, mas poucos conhecem a respeito de mapeamento e mapeamento computacional em particular. 
Para Korte (2001), a alta gerência tem que estar convencido da importância do SIG dentro da organização. Sem isto o sistema pode não chegar a ter seu potencial completo.

Um SIG também deve ter uma clara definição dos objetivos. Esta visão serve como um alicerce para a implementação do sistema. Alguns programas SIG são muito ambiciosos e tentam fazer de tudo e muito rápido. Outros, usam tão pouco da tecnologia que acabam servindo a um único departamento da organização e negligenciando outros.

Para Korte (2001), existem ainda alguns outros pontos chave:

1- Conversão de dados e manutenção

A maior porção dos custos de um SIG é a conversão de dados no formato digital. O custo desta conversão pode variar entre $60 \%$ e $80 \%$ do total de custos da implementação de um SIG. Muito deste custo vem do trabalho intensivo de digitalizar mapas e coletar a informação existente. Entretanto, é importante considerar quais informações são relevantes para serem colocadas dentro do sistema.

Outro ponto que deve ser observado é a verificação dos dados digitais antes deles serem inseridos no banco de dados do SIG.

\section{2- Treinamento dos usuários}

Um SIG pode utilizar um grande número de pessoas dentro do projeto. Tipicamente, eles têm pouco conhecimento de sistemas em geral e nenhum de SIG. Para Korte (2001), "muitos querem fazer bem seu trabalho. Para isso eles devem sentir confiança no que estão fazendo e precisam ter o conhecimento e habilidades necessárias. Trabalhar com novas tecnologias como SIG pode destruir a confiança do empregado. Isto pode ser convertido através de um planejado programa de treinamento".

O treinamento deve considerar um tempo de aprendizado que pode variar de três a seis meses. Um SIG requer um demanda maior por novas habilidades por parte do pessoal que irá usá-lo. 
3- Comunicação dos dados

Para Korte (2001), poucas organizações confinam o uso do SIG em um único departamento. Em sua maioria, vários departamentos acessam as informações. A rede de comunicação de dados é o mais freqüente veículo usado para distribuição de dados.

Um SIG planejado a longo prazo deve levar em consideração o seu uso por vários departamentos mesmo que ele tenha se originado em um departamento específico.

\section{4- Customização do software}

Os SIGs que são vendidos atualmente tem sua interface de acordo com as necessidades de uma grande quantidade de usuários. Para Korte (2001), o SIG deve ser customizado para as necessidades particulares do usuário. O mesmo salienta ainda que, para se obter um máximo desempenho, a customização se faz necessária.

\section{5- Suporte ao usuário}

Para Korte (2001), a implementação e gerenciamento do SIG é uma tarefa muitas vezes difícil e uma maneira de aumentar a probabilidade de sucesso na implementação e manutenção do sistema é envolver uma pessoa com experiência na área ou então ter um sistema de suporte técnico. O suporte técnico poderá preparar uma pessoa dentro da organização para realizar as tarefas de suporte posteriormente. O tempo que o técnico leva para isto pode variar, mas dois meses deve ser considerado o mínimo.

\subsection{Problemas encontrados na implantação e gerenciamento de um SIG.}

Para Korte (2001), alguns riscos devem ser considerados na implementação do SIG:

Não considerar riscos: muitas organizações criam um escopo de projeto que pode vir a falhar por não considerar problemas que podem ocorrer. Quando a organização não antecipa estes problemas ou não consegue determinar sua 
magnitude, eles ficam mais difíceis de resolver, o que pode fazer o projeto cair em descrédito.

Superestimar benefícios: isto pode gerar insatisfação caso o projeto não atinja as expectativas iniciais.

Falha ao definir objetivos: objetivos dão um senso de direção e propósito para qualquer programa. Sem metas bem definidas fica difícil medir o sucesso.

Falta de planejamento a longo prazo: este deve ser definido após a especificação dos objetivos iniciais. O plano deve incluir a seqüência de elementos chaves, seu agendamento e a atribuição das responsabilidades. Este plano também poderá servir como base para o desenvolvimento dos requisitos de pessoal, compra de equipamentos e requisição de orçamentos.

Falta de suporte dos dirigentes: um SIG requer frequentemente a aprovação por parte dos dirigentes da organização. A falta de conhecimento da tecnologia pode causar dificuldades ou demora na tomada de decisão.

Falta de envolvimento do usuário: usuários necessitam ter seus papéis no planejamento, na seleção e implementação de um SIG. Para Korte (2001), caso eles não tomem parte neste processo, duas coisas negativas podem ocorrer. "Primeiro, a organização perde a oportunidade de se beneficiar da experiência dos usuários quando estão planejando e selecionando o sistema. Segundo, quem é mais qualificado para falar a respeito das necessidades de um SIG do que as pessoas irão utilizá-lo?"

Solução dos problemas existentes: um SIG pode aumentar a produtividade, integrar operações entre departamentos e melhor organizar seus dados. Entretanto, ele não virá resolver problemas de gerenciamento. Tais problemas precisam ser resolvidos antes do SIG alcançar todo seu potencial.

Continuação do uso de sistemas manuais: algumas organizações escolhem por manter o processo manual quando um processo automático é instalado. Eles precisam se assegurar de que tem uma cópia de segurança caso algo saia errado. Ou ainda, precisam fazer com que os novos processos estejam trabalhando perfeitamente antes de deixarem de usar o processo antigo. A 
continuação do uso do processo manual pode minar o novo sistema pois os usuários podem usar o processo antigo e evitar o novo.

Falha no treinamento: um pessoal mal treinado não irá usar todo o potencial do SIG. Em muitos casos poderá criar insegurança por parte do pessoal. Neste caso, se ainda existir o processo manual o pessoal poderá optar por ele.

Sistema que não pode ser expandido ou modificado: O Sig deve prever mudanças no ambiente e na tecnologia. A tecnologia muda rapidamente e o sistema deve permitir que a base de dados possa ser transportada para o novo hardware sem grandes modificações. Para Korte (2001), a base de dados é o principal investimento em um SIG e deve ter uma vida útil de vinte anos ou mais.

Estouro no orçamento: qualquer programa tem um sério problema quando estoura o orçamento. O estouro do orçamento pode resultar de um projeto mal gerenciado e controlado ou de um orçamento subestimado desde o início. 


\section{Pesquisa-ação e pesquisa qualitativa}

Esta seção tem como objetivo apresentar a pesquisa-ação e a pesquisa qualitativa. As considerações feitas aqui nortearam a execução da presente pesquisa.

Segundo Coughlan e Coghlan (2002), várias são as características da pesquisa-ação:

1. Pesquisa em ação mais do que pesquisa sobre a ação.

2. A pesquisa-ação é participativa.

3. Ocorre simultaneamente com a ação.

4. Existe uma seqüência de eventos e uma abordagem para resolver o problema.

Primeiro, a pesquisa-ação foca a pesquisa em ação mais do que a pesquisa sobre a ação. A idéia central é de que a pesquisa-ação usa a aproximação científica para estudar a solução de importantes assuntos sociais e organizacionais junto com aqueles que vivenciam isto diretamente. A pesquisaação trabalha através de um ciclo de quatro passos: planejamento, tomada de ação e avaliação da ação, levando para mais planejamento e assim por refazendo-se o ciclo.

Segundo, a pesquisa-ação é participativa. Membros do sistema que está sendo estudado participam ativamente do processo descrito anteriormente.

Esta participação contrasta com a pesquisa tradicional onde os membros do sistema são objetos do estudo. 
Terceiro, a pesquisa-ação é simultânea com a ação. O objetivo é criar uma ação mais efetiva enquanto constrói-se simultaneamente o conhecimento científico.

Finalmente, a pesquisa-ação é uma seqüência de eventos e uma aproximação para a solução do problema. Como uma seqüência de eventos, isto compreende ciclos iterativos, de um conjunto de dados que alimentam 0 pessoal envolvido, analisando os dados, planejando a ação, tomando e avaliando a ação. Levando para mais reunião de dados e assim por diante. Ainda segundo Coughan (2002, p.223),

"os resultados esperados da pesquisa-ação não são soluções imediatas para o problema, mas um importante aprendizado a partir de resultados intencionais e não intencionais e uma contribuição para o conhecimento científico e criação de teorias."

\subsection{Principais características da pesquisa-ação}

Segundo Gummessom (2000), existem dez grandes características da pesquisa-ação:

1. Pesquisadores que tomam ação: os pesquisadores não são meros observadores, mas trabalham ativamente $e$ fazem as coisas acontecerem.

2. A pesquisa-ação sempre envolve dois objetivos: resolver um problema e contribuir com a ciência. Os pesquisadores devem agir e refletir no que aconteceu para contribuir com a teoria e construção do conhecimento.

3. A pesquisa-ação é interativa: requer cooperação entre pesquisadores e participantes e requer um contínuo ajustamento para novas informações e novos eventos.

4. A pesquisa-ação almeja o entendimento dos fenômenos e reconhecimento de sua complexidade. As organizações são sistemas sócio-técnicos dinâmicos e os pesquisadores devem ter uma ampla visão de como o sistema trabalha e devem estar habilitados a mover 
entre uma estrutura formal e técnica e subsistema informal de pessoas Nadler and Thusman ${ }^{5}$ (1984 apud COUGHLAN e COGHLAN, 2002).

5. Pesquisa ação é fundamentalmente sobre mudanças: ela é aplicável para compreender, planejar e implementar mudanças na organização. A pesquisa-ação é fundamentalmente sobre mudanças, conhecimento e habilidades na organização.

6. A pesquisa-ação requer um entendimento de ética da estrutura de trabalho, valores e normas dentro das quais são utilizadas em um contexto particular. Valores e normas que existem a partir dos princípios éticos tipicamente foca em como os pesquisadores trabalham com os membros da organização.

7. A pesquisa-ação pode incluir todos os tipos de métodos de reunião de dados. A pesquisa-ação não impede o uso reunião de métodos de dados a partir da pesquisa tradicional. Ferramentas quantitativas e qualitativas tais como entrevistas e pesquisas podem ser usadas. $O$ importante na pesquisa-ação é que o planejamento e uso destas ferramentas devem ser bem pensadas com os membros da organização e serem claramente integradas no processo de pesquisa-ação.

Ainda segundo Gummessom (2000), uma entrevista ou pesquisa pode gerar sentimentos de ansiedade, suspeitas, apatia e hostilidade ou criar expectativas no pessoal envolvido. Se os pesquisadores não atentarem para isto e focarem somente a coleção de dados, eles podem estar perdendo dados importantes que podem ser críticos para o sucesso de seu projeto.

8. A pesquisa-ação requer um amplo pré-entendimento do ambiente da corporação, as condições do negócio, da estrutura e dinâmica da operação do sistema.

\footnotetext{
${ }^{5}$ Nadler, D. e Thusman, M. (1984) "A congruence model for diagnosing organizational behavior". In Kolb, D.A., Rubin, LM and Mclntyre, J.M. Organisational Psychology, Readings on Human on Human Bahavior in Organizations, $4^{\text {th }}$ ed. Prentice-Hall, Englewood Cliffs, NJ, pp. 587-603. apud Coughlan, P. e Coghlan D. (2002) Action research for operations management. International Journal Operations \& Production Management . Vol. 22, n.2, p. 225.
} 
9. A pesquisa-ação deve ser conduzida em tempo real: enquanto o estudo de caso retrata fatos históricos, a pesquisa-ação procura trabalhar com os dados do presente.

10. A pesquisa-ação requer seu próprio critério de qualidade: ela não deve ser julgada por critérios positivistas, mas com seus próprios critérios.

Reason e Bradbury ${ }^{6}$ (2001 apud COUGHLAN e COUGHLAN, 2002) apontam algumas questões que eles consideram ser importantes para uma pesquisaação de qualidade:

1. Como a pesquisa-ação reflete a cooperação entre o pesquisador e os membros da organização?

2. A pesquisa-ação é guiada para resultados práticos? O projeto de ação é governado por constantes e iterativas reflexões como parte do processo de mudança ou melhora organizacional?

3. A pesquisa-ação resulta em novas infra-estruturas ? Sustenta mudanças fora do projeto?

\subsection{Quando a pesquisa-ação é apropriada}

Em geral a pesquisa ação é apropriada quanto a questão da pesquisa relata uma larga série de ações em um dado grupo, comunidade ou organização, procurando mostrar para os membros de um grupo como e porque suas ações podem mudar ou melhorar o trabalho.

\subsection{Implementando a pesquisa-ação}

Segundo Coughlan e Coghlan (2002) ciclo da pesquisa-ação compreende 3 tipos de passos:

1. Pré-passo: para entender o contexto e propósito.

\footnotetext{
${ }^{6}$ Reason P. e Bradbury H. (2001). Handbook of action research, Sage, Thousand Oaks, CA. apud Coughlan, P. e Coghlan D. (2002) Action research for operations management. International Journal Operations \& Production Management . Vol. 22, n.2, p. 226.
} 
2. Seis passos principais: para reunir e analisar dados e planejar, implementar e avaliar a ação.

3. Um meta passo para monitorar.

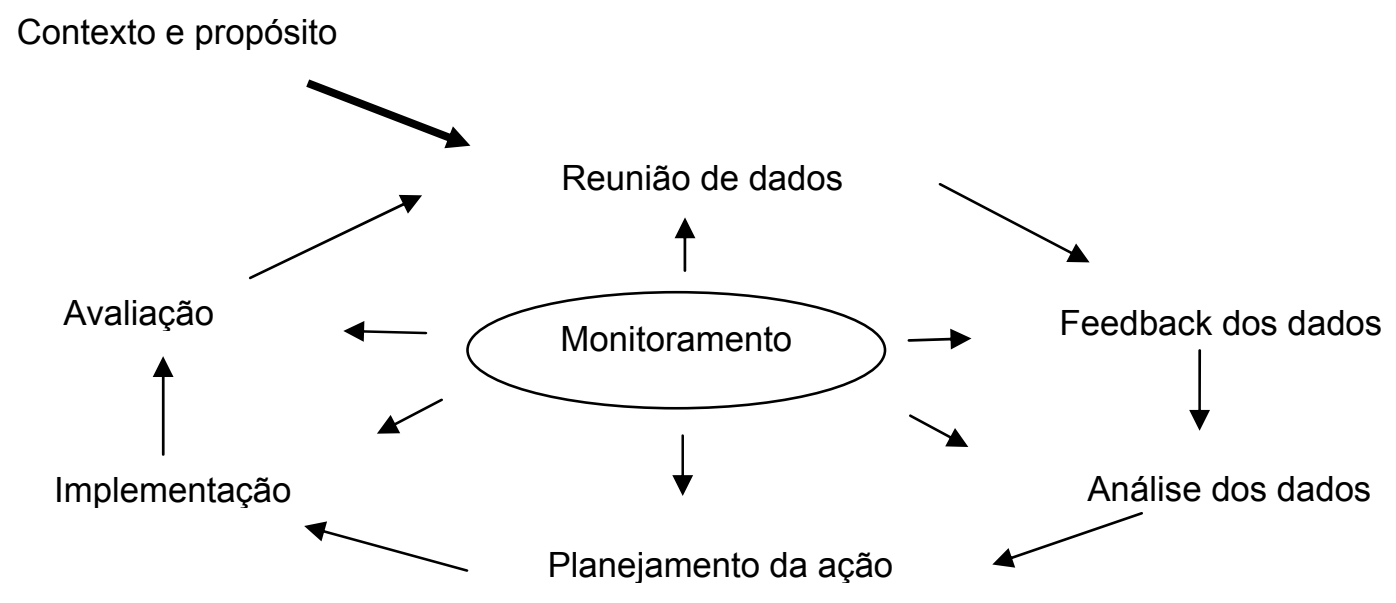

Fonte: adaptado de Coughlan e Coghlan (2002)

Figura 5 - Ciclo da pesquisa-ação

O pré passo é dirigido para duas questões que dizem respeito à ação e à pesquisa:

1. Quais são as razões para a ação?

O ciclo da pesquisa-ação inicia com os membros chave do desenvolvimento da organização um entendimento do contexto do projeto de ação, que leva a duas outras questões:

- Por que este projeto é desejável?

- Quais são as forças econômicas, políticas, sociais, e técnicas dirigidas para necessidades da ação?

A análise destas forças identifica sua origem, seu potencial e natureza das demandas que são criadas no sistema. 


\section{Quais são as razões para a pesquisa?}

Isto envolve responder por que este projeto de ação é estudado, e qual sua contribuição para criar conhecimento.

\section{Passos principais}

Dados são reunidos de diferentes maneiras dependendo do contexto. Existem dados que são referenciados como dados "duros". Estes dados são reunidos através de estatísticas, relatórios contábeis, financeiros e de marketing. Existem dados que são chamados de "leves". Estes são reunidos através da observação, discussão e entrevistas.

Para o pesquisador a geração de dados vem através do ativo envolvimento no dia a dia dos processos organizacionais.

1. Os dados não são gerados somente através da participação e ação das equipes de trabalho, problemas sendo resolvidos, decisões sendo tomadas, mas também através das intervenções que são criadas para avançar no projeto. Algumas destas observações e intervenções são criadas em conjuntos formais - encontros e entrevistas. Algumas são criadas em encontros informais - café, almoço, etc.

2. Feedback de dados: o pesquisador reúne os dados para fazer uma análise.

3. Análise dos dados: a análise se possível deve ser colaborativa. Os membros da organização devem participar já que conhecem melhor a organização e sabem como o trabalho é feito.

Planejando a ação: o planejamento da ação também é um conjunto de atividades. Elas determinam quais são as necessidades de mudanças, como e quando elas serão feitas. A pesquisa-ação orienta o grupo e o gerente determina o que eles devem fazer e quando. 
4. Implementação: Os participantes e o pesquisador implementam o plano de ação. Isto envolve criar o desejo de mudança e segui-los através da colaboração com elementos chave na organização.

5. Avaliação: A avaliação envolve reflexão dos resultados da ação, tanto os intencionais como os não intencionais, uma revisão dos processos na ordem para que o próximo ciclo de planejamento e ação possa beneficiar da experiência do ciclo completado.

\subsection{Diferença entre pesquisa-ação e consultoria}

A pesquisa-ação pode algumas vezes ser confundida com uma consultoria o que pode descaracterizar seu objetivo acadêmico. Gummesson (2000) apresenta algumas características que diferenciam a pesquisa-ação da consultoria:

1. Pesquisadores que trabalham em uma pesquisa-ação devem ser mais rigorosos em sua investigação e documentação.

2. Pesquisadores requerem justificativas teóricas, enquanto consultores requerem justificativas empíricas.

3. Consultores trabalham sob um tempo curto e orçamento reduzido.

4. Consultores têm um envolvimento linear: envolvem-se, analisam, tomam ações e se desligam. Os pesquisadores por sua vez estão mais comprometidos com o ciclo da pesquisa-ação.

Thiollent (2000) também ressalta a diferença entre consultores e pesquisadores, onde os primeiros estão mais preocupados com os lucros sem contribuírem efetivamente para o conhecimento.

\subsection{A pesquisa-ação nas organizações}

Para Thiollent (2000), a pesquisa-ação pode ser realizada em organizações empresariais, de capital privado ou estatal. 
A área organizacional oferece algumas barreiras para os pesquisadores pois ela é marcada pelo espírito empresarial, mudanças controladas e ainda a intocabilidade das relações de poder, onde as decisões são fortemente concentradas.

Thiollent (2000) salienta ainda a importância da pesquisa-ação nas organizações como instrumento de obtenção das informações e na solução de problemas de ordem técnico-organizativa. Seria um meio de produzir e difundir conhecimentos especializados que possam ser utilizados por todas as pessoas da organização.

Ainda segundo Thiollent (2000), "na medida do possível e supondo que os obstáculos sejam superáveis, podemos considerar que a pesquisa-ação consistiria em estabelecer uma forma de cooperação entre pesquisadores, técnicos e usuários para resolverem conjuntamente problemas de ordem organizativas e tecnológicas. O processo seria orientado de modo que os grupos considerados pudessem propor soluções ou ações concretas e ao mesmo tempo, adquirir novas habilidades e conhecimentos"

\subsection{0 campo de estudo}

Para Flick (2004), o acesso ao campo de estudo é uma questão crucial na pesquisa qualitativa. Vários são os problemas enfrentados pelos pesquisadores dentro do ambiente a ser estudado. Como o pesquisador garante a colaboração de seus participantes? Como ele consegue não apenas que se demonstre a disponibilidade, mas que esta também leve a entrevistas concretas ou a outros dados? Estes são dois problemas que o pesquisador deve tentar responder.

As competências comunicativas do pesquisador são vitais para solucionar estes problemas. O pesquisador deve adotar posturas apropriadas para que possa ter acesso a pessoas responsáveis pela autorização da pesquisa, como também às pessoas que serão entrevistadas, observadas ou treinadas para que consiga todas as informações necessárias. OU seja, a entrada em uma instituição depende do estabelecimento de relações. Flick (2004, p.72) ainda salienta que: 
"a pesquisa instabiliza a instituição em três implicações: que as limitações de suas próprias atividades vão acabar sendo reveladas, que os motivos ocultos da pesquisa são e continuam sendo pouco claros para a instituição, e finalmente, que não há razoes consistentes para recusar as solicitações da pesquisa."

O pesquisador também deve levar em consideração o problema de acesso aos indivíduos da instituição. A principal dificuldade encontrada diz respeito à disponibilidade de pessoal. Pelo fato das organizações trabalharem em seu quadro de funcionários reduzidos, os indivíduos normalmente tem uma sobrecarga de trabalho, o que dificulta o trabalho do pesquisador. Em conseqüência o acesso pode se dar a pessoas sem experiência na área, como estagiários que podem ser alocados para atender ao pesquisador.

\subsection{A documentação de dados da pesquisa}

Todos os dados colhidos na pesquisa-ação devem ser documentados pelo pesquisador. Para Flick (2004), o enriquecimento contextual dos enunciados ou atividades devem ser um dos componentes principais da coleta de dados. Isto pode ser obtido através dos diários de pesquisa ou das notas de campo. Procedimentos que transformam as relações estudadas em textos, que constituem base para análises efetivas.

Notas de campo

As notas de campo são o meio clássico de documentação de dados na pesquisa qualitativa. Segundo Flick (2004) estas notas devem ser feitas tão logo quanto possível. Se possível elas devem ser feitas imediatamente após o contato de campo.

A produção dos textos tem início nas notas feitas em campo. Flick (2004) destaca a importância da percepção do pesquisador em documentar informações relevantes.

Diário de pesquisa

Os diários de pesquisa são usados mais comumente quando a pesquisa envolve mais de um pesquisador. Neste diário são registrados os processos de aproximação de um campo e as experiências e problemas em contato com o 
campo, com os entrevistados ou participantes, bem como na aplicação dos métodos.

Ao tomar nota das intervenções, o pesquisador deve registrar apenas o conteúdo necessário para responder à questões da pesquisa. 


\section{Projeto de pesquisa}

A Metodologia utilizada na implantação do SIG no posto de bombeiros foi adaptada das metodologias apresentadas nesta dissertação. Não é objetivo deste trabalho propor uma nova metodologia e sim apresentar como o sistema foi implantado usando como guia as metodologias de Clarke (1991) e Huxhold (1995) e em seguida apresentar os resultados obtidos.

Para implantação do sistema foi criado um roteiro logo no início das atividades no posto de bombeiros. Este roteiro foi algumas vezes modificado e teve o prazo de algumas atividades estendido durante sua execução.

Seguindo o ciclo de pesquisa-ação de Coughlan e Coghlan (2002), foi realizado o pré-passo onde foi possível contextualizar o problema e definir o objetivo do trabalho. Foram então respondidas as perguntas já colocadas por Coughlan e Coghlan:

1 - Quais as razões para a ação?

R: Tornar os bombeiros aptos a utilizar esta tecnologia.

2 - Por que este projeto é desejável ?

R: O sistema de informação geográfica implantado no posto de bombeiros poderá tornar o trabalho do bombeiro mais fácil e rápido já que o mapa em formato digital possui uma quantidade maior de informações em relação ao mapa impresso e possibilita várias maneiras de consultá-las.

3 - Quais as forças econômicas, políticas, sociais e técnicas dirigidas para a necessidade da ação? 
R: O projeto após sua conclusão permite ao posto de bombeiros prestar um melhor serviço à população.

4 - Quais as razões para a ação?

R: Com este projeto de ação foi possível apresentar uma tecnologia que não era conhecida no posto de bombeiros.

\subsection{Roteiro das atividades}

1. Análise das necessidades: Nos primeiros encontros foram definidas as principais necessidades da organização. Foi decidida em conjunto com o bombeiro responsável pelo posto qual a principal necessidade a ser atendida. Neste caso a localização precisa dos pontos de abastecimento.

2. Projeto do sistema: Nesta etapa foi determinada a tecnologia a ser utilizada e coletados os dados iniciais do sistema. Ao contrário das metodologias estudadas que determinam que sejam avaliadas várias tecnologias e escolhida a que melhor se encaixa nas necessidades, a tecnologia já estava previamente definida e procurou-se adequar as necessidades do posto a ela. Como o resultado obtido foi satisfatório ela foi aprovada e utilizada. Isto ocorreu devido a dificuldade em se ter acesso a várias tecnologias existentes e conhece-las todas levaria tempo considerável e poderia comprometer a execução do projeto.

O software escolhido para a criação do sistema foi o Autocad Map por ser uma tecnologia tecnologia já conhecida do pesquisador e que atendeu às necessidades do posto de bombeiros.

3. Especificação do projeto: Após a escolha do software a ser utilizado foi preparado o mapa e estruturado o banco de dados do sistema. Em um primeiro momento foi feita a estruturação do banco de dados de hidrantes e após a implantação destes foi feito a estruturação do banco de dados dos registros de recalque. 
4. Projeto piloto: a etapa seguinte foi criar um projeto piloto. Ele foi importante para determinar quais as dificuldades encontradas na criação do sistema.

5. Preparação do hardware e do software: nesta etapa foi preparado o computador para instalação do software e em seguida do projeto piloto.

6. Apresentação do projeto piloto: após a instalação do projeto piloto este foi apresentado aos usuários. Foram identificadas as primeiras dificuldades que eles tiveram ao conhecerem o sistema e sugestões foram colhidas para melhoria do mesmo.

7. Preparação da interface: como a interface foi percebida depois da apresentação do projeto piloto como fator determinante para a utilização eficaz do sistema, esta etapa foi adicionada ao roteiro e trabalhada assim que o sistema final ficou pronto.

8. Treinamento: nesta etapa o pessoal envolvido na utilização do sistema recebeu treinamento para consultar os pontos de abastecimento e também para alterar e incluir novos pontos no mapa.

9. Migração do projeto piloto para o sistema final: esta etapa consistiu em corrigir os problemas encontrados na criação do projeto piloto e agregar as sugestões dos usuários.

10. Implantação do sistema final: Após o treinamento foi implantado o sistema finalizado para utilização. A versão final já inclui todos os pontos de abastecimento do município.

11. Monitoramento: Com o sistema final já implantado e pessoal treinado a última etapa consistiu em monitorar por um período o uso do sistema e verificar se o bombeiro consegue realizar as tarefas de consultar, alterar e incluir novos pontos de abastecimento. 


\subsection{Análise das necessidades}

O contato inicial com o posto de bombeiros de Rio Claro foi feito através do Núcleo de Atividades Técnicas (NAT), no setor de atendimento ao público.

Em entrevistas informais foram encontradas várias necessidades de melhoria nos sistemas de informação do posto. Constatou-se, por exemplo, que existem informações que são digitadas mais de uma vez em diferentes ambientes para consolidação de dados e geração de gráficos. Este procedimento acaba gerando trabalho desnecessário se houvesse um sistema de informação mais integrado.

Outra necessidade encontrada foi a criação de um sistema para localização dos pontos de abastecimento na cidade. O corpo de bombeiros utiliza-se de um mapa impresso onde são fixados alfinetes coloridos para identificar os pontos de abastecimento. Este método segundo os próprios bombeiros tem-se mostrado ineficaz já que a consulta a ele é demorada e também porque não há possibilidade de representar todos os pontos de abastecimento, como os registros de recalque. Na região central eles são muitos e estão muito próximos, dificultando a representação por alfinetes coloridos.

Portanto, atualmente no mapa impresso existem apenas os hidrantes identificados com alfinetes.

Ao final das entrevistas preliminares com os bombeiros do NAT ficou decidido procurar uma solução em SIG para melhorar as consultas aos pontos de abastecimento, devido à importância de se ter melhores informações para uma tomada rápida de decisões em situações de emergência.

\subsection{Projeto e Escolha do Sistema}

Decidido o foco de ação o próximo passo foi encontrar uma solução mais adequada às necessidades. Foi levantada a possibilidade de se usar um sistema de informação geográfica e a ferramenta escolhida foi o Autocad Map 2004. A decisão deste software se deu por algumas razões: 
1. A prefeitura municipal de Rio Claro forneceu um mapa do município no formato do Autocad Map.

2. O software possui todas as funcionalidades necessárias.

3. O ambiente não se mostrou de difícil aprendizado.

4. Existem várias publicações sobre o software, o que facilita o suporte ao aprendizado.

5. Permite fácil edição e alteração por parte dos usuários.

O próximo passo foi a seleção do pessoal envolvido. Em um primeiro momento foi decidido que um bombeiro do NAT iria acompanhar a execução do projeto e dar suporte necessário.

O contato foi estabelecido semanalmente com visitas agendadas além de contatos telefônicos para esclarecimento de dúvidas. Estes encontros foram importantes para estabelecer contato com os primeiros usuários do sistema e descobrir quais eram suas primeiras dificuldades. A troca de experiência também foi fundamental, pois nestes encontros informais foi possível descobrir como são os procedimentos dentro do posto quando surge a necessidade de atendimento de uma ocorrência.

Estes contatos também foram importantes para estreitar a relação entre o pesquisador e o pessoal envolvido na pesquisa.

\subsection{Especificação do Projeto}

\subsubsection{Mapa do município}

Segundo Delazari (2004), a linguagem cartográfica depende da informação geográfica que está sendo representada e do contexto no qual os símbolos aparecerão no mapa. O tipo e a quantidade de contraste entre os símbolos são fatores importantes na definição do mapa. Para tornar mapas legíveis é necessário que exista um contraste entre os objetos que deseja representar no mapa e os outros elementos que estão representados. 
De acordo com Beguin e Pumain (1994) ${ }^{7}$ apud Câmara et al. (1996), a linguagem cartográfica utiliza sete variáveis visuais: forma, tamanho, cor, valor, textura, grão e orientação. Forma, tamanho e cor são os fatores cuja variabilidade melhor permite ao usuário entender o resultado de uma consulta.

Para Câmara et al. (1996), para informações qualitativas sobre objetos pontuais ou lineares, a apresentação deve ser feita variando a forma, a orientação ou a cor; se as informações são sobre objetos poligonais, varia-se a cor. Caso a informação seja quantitativa, varia-se o tamanho ou a cor. A variável forma só permite ao usuário determinar informação qualitativa, precisando estar associada a outras variáveis (cor, tamanho, textura) para permitir derivar informação quantitativa. A variação do tamanho dos objetos no mapa permite avaliar suas grandezas. Na prática esta variação é limitada pelas dimensões físicas observáveis pelo olho humano e pelo conjunto de dados apresentados (por exemplo, ao representar um conjunto de cidades por meio de pontos a variação do tamanho pode atrapalhar a visualização de cidades vizinhas).

Dentre as variáveis visuais, a cor é a que melhor permite separar os fenômenos de natureza diferente. A variação de tom e contrastes de cores possibilita ao usuário determinar diferenças relativas entre os valores de um fenômeno. Por exemplo, em cartas náuticas, diferenças de tons de azul indicam variação na profundidade; em mapas de temperaturas, cores mais próximas do vermelho denotam temperaturas mais quentes.

O mapa obtido junto à Prefeitura Municipal teve que passar por algumas modificações antes de dar inicio à inclusão dos pontos de abastecimento.

No projeto de pesquisa, uma das primeiras etapas foi determinar as cores do mapa. O Autocad Map por padrão trabalha com uma tela de fundo preto, portanto cores muito escura não foram utilizadas. Outras cores de fundo foram apresentadas, mas os usuários preferiram utilizar o preto.

\footnotetext{
${ }^{7}$ M. Béguin e D. Pumain. (1994) La Representation des Données Geographiques. Statistique et Cartographie. Armand Colin, apud CÂMARA, G.; MEDEIROS, C.B., CASANOVA

M.A.,HEMERLY A., MAGALHÃES G., (1996). Anatomia de sistemas de informação geográfica. Escola de Computação, SBC, p. 96
} 
As cores vermelho, verde e amarelo foram usadas para identificar os hidrantes. Ficou determinado que estas cores não seriam usadas para outros elementos no mapa. O processo de padronização de cores consumiu várias horas de trabalho já que o mapa possuía o mesmo objeto em cores diferentes.

Outra alteração feita foi uma melhor organização dos objetos em suas respectivas camadas. Foi criada uma camada para cada tipo de objeto no mapa e em cada camada foi colocada uma cor padrão.

A organização do mapa em camadas permite que o usuário troque a cor de um conjunto de elementos de maneira fácil e rápida. Por exemplo, ele pode trocar a cor de todas as identificações de ruas de azul claro para laranja. Além disso, através das camadas é possível ocultar e exibir elementos no mapa permitindo melhorar a visualização de informações.

Foi necessária em algumas ocasiões a saída a campo para verificar a existência de algumas ruas do município que ainda não haviam sido representadas no mapa.

Em outras ocasiões o mapa em formato digital foi conferido com um mapa impresso do município para também verificar a exatidão da representação de ruas e avenidas.

\subsubsection{Visualização de dados geográficos}

Para Câmara et al. (1996) a interface de um SIG deve oferecer facilidades para visualização de campos e objetos geográficos no espaço $2 \mathrm{D}$ e 3D. A interface deve ajudar o usuário a formular consultas utilizando a informação gráfica presente na tela. Deve, ainda, prover formas de combinar o resultado de várias consultas e de construir legendas que ajudem o usuário a examinar o conteúdo apresentado.

É fundamental para Câmara et al. (1996) que o ambiente possua funções para movimentar o mapa pela tela já que a quantidade de informações geográfica tende a ser grande e os dispositivos de exibição (monitores) normalmente são pequenos. O sistema de visualização deve se preocupar não apenas em 
mostrar resultados, mas também em oferecer ao usuário facilidades para manipular os elementos visualizados.

\subsubsection{A seleção de hidrantes}

Após as correções no mapa o bombeiro do NAT forneceu uma lista de hidrantes na cidade esta lista possuía 67 hidrantes que em um segundo momento foi atualizada para 86 hidrantes.

No posto de bombeiros existe um bombeiro responsável pelos hidrantes. Ele tem como função inspecionar os hidrantes para mantê-los em condições de uso. No posto de bombeiros de Rio Claro esta pessoa também participa da pesquisa já que trabalha no atendimento telefônico e terá contato direto com o sistema proposto.

\subsubsection{A inclusão dos Registros de Recalque}

Após a inclusão de todos os hidrantes no mapa, o próximo passo foi incluir os registros de recalque.

Todo projeto que é entregue ao NAT tem seus dados inseridos em um banco de dados próprio do posto chamado SICAT (Sistema de Cadastramento de Atividades Técnicas). Através dos dados registrados neste sistema foi possível fazer um levantamento da maioria dos registros de recalque da cidade. $O$ SICAT do posto de bombeiros de Rio Claro possui aproximadamente 3.600 projetos cadastrados.

Alguns problemas foram encontrados durante o trabalho de levantamento. $O$ sistema SICAT não identifica duplicidade de registros. Como resultado, o projeto pode ser cadastrado duas vezes no sistema. Isto ocorre quando o projeto de um estabelecimento já foi cadastrado e depois devido à mudança de proprietário, inquilino este volta a dar entrada no projeto para abertura de outra empresa no mesmo local.

Como resultado houve a necessidade de realizar um filtro neste banco para eliminar estas duplicidades. 
Outra dificuldade encontrada foi a precisão de informações de projetos muito antigos. Estes foram descartados na pesquisa. Foram considerados os projetos que possuem registros de recalque que foram cadastrados no SICAT a partir do ano de 2001 até a presente data. Também foram inseridos no sistema os registros de recalque de todos os edifícios da cidade não importando neste caso a data de entrada do projeto.

Parte dos projetos antigos precisam ser revisados e conferidos. Este trabalho ficará a cargo do pessoal do NAT após a conclusão desta pesquisa. Desta forma o pessoal poderá realizar este trabalho dentro de suas possibilidades levando em consideração um prazo de tempo maior. Além disso, a presente pesquisa tem como um objetivo secundário dar autonomia ao bombeiro para que ele possa incluir e alterar os pontos de abastecimento no mapa. Isto foi conseguido através do programa de treinamento executado no posto.

De posse desta lista foi criado um banco de dados no Microsoft Access com duas tabelas. Uma para do cadastro de informações dos hidrantes e outra para cadastro das informações dos registros de recalque. A seguir uma descrição da estrutura de cada tabela.

\begin{tabular}{l|l|l}
\hline Nome Campo & Tipo de dados & Informação a ser armazenada \\
\hline Num & Numérico & Código do hidrante \\
\hline C-S & Texto & Determinar se o hidrante é do tipo coluna ou subterrâneo \\
\hline Endereço & Texto & Endereço de localização do hidrante \\
\hline Quad & Texto & $\begin{array}{l}\text { Quadrante no mapa impresso onde se localiza o } \\
\text { hidrante }\end{array}$ \\
\hline Bairro & Texto & Bairro de localização do hidrante \\
\hline PrEst & Texto & $\begin{array}{l}\text { Ponto de referência para auxiliar no localização do } \\
\text { hidrante }\end{array}$ \\
\hline PrDin & Numérico & Pressão estática do hidrante \\
\hline Vazão & Numérico & Pressão Dinâmica do hidrante \\
\hline Obs & Numérico & Vazão de água do hidrante em litros por minuto \\
\hline Cor & Texto & Observações sobre o hidrante \\
\hline Quadro 13 Estrutura da tabela de hidrantes
\end{tabular}

Quadro 13 - Estrutura da tabela de hidrantes 


\begin{tabular}{l|l|l}
\hline Nome Campo & Tipo de dados & Informação a ser armazenada \\
\hline Código & Numérico & Código do registro de recalque \\
\hline Num. Protocolo & Texto & Número do projeto que foi protocolado \\
\hline Ocupação & Texto & Finalidade do estabelecimento \\
\hline Endereço & Texto & Endereço do estabelecimento \\
\hline Numero & Texto & Número do estabelecimento \\
\hline Bairro & Texto & Bairro de localização do registro de recalque \\
\hline Município & Texto & Município \\
\hline Área Construída & Numérico & Área construída do estabelecimento \\
\hline Reservatório & Numérico & Indica o tipo de reservatório \\
\hline $\begin{array}{l}\text { Endereço do } \\
\text { registro }\end{array}$ & Texto & Indica onde está posicionado o registro de recalque \\
\hline $\begin{array}{l}\text { Capacidade do } \\
\text { reservatório }\end{array}$ & Numérico & Capacidade de armazenamento em litros de água. \\
\hline Quadro 14 Estrutura
\end{tabular}

Quadro 14 - Estrutura da tabela de registros de recalque

Neste banco de dados foi criada uma interface para que o usuário possa realizar consultas, alterações ou novas inclusões nesta tabela.

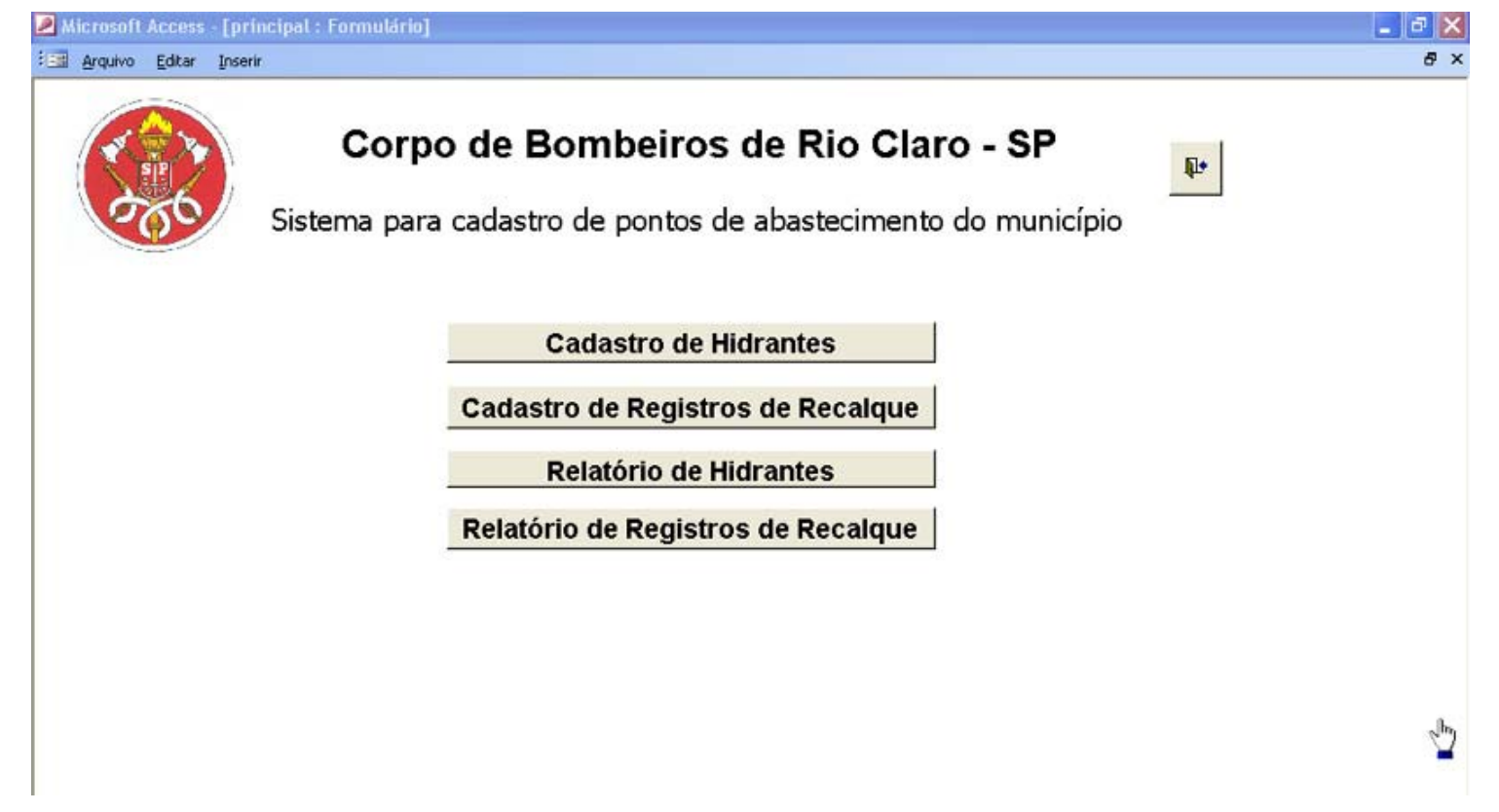

Figura 5 - Tela Inicial do Sistema

O usuário, ao clicar no botão "Cadastro de hidrantes" tem acesso a tela de cadastro. 


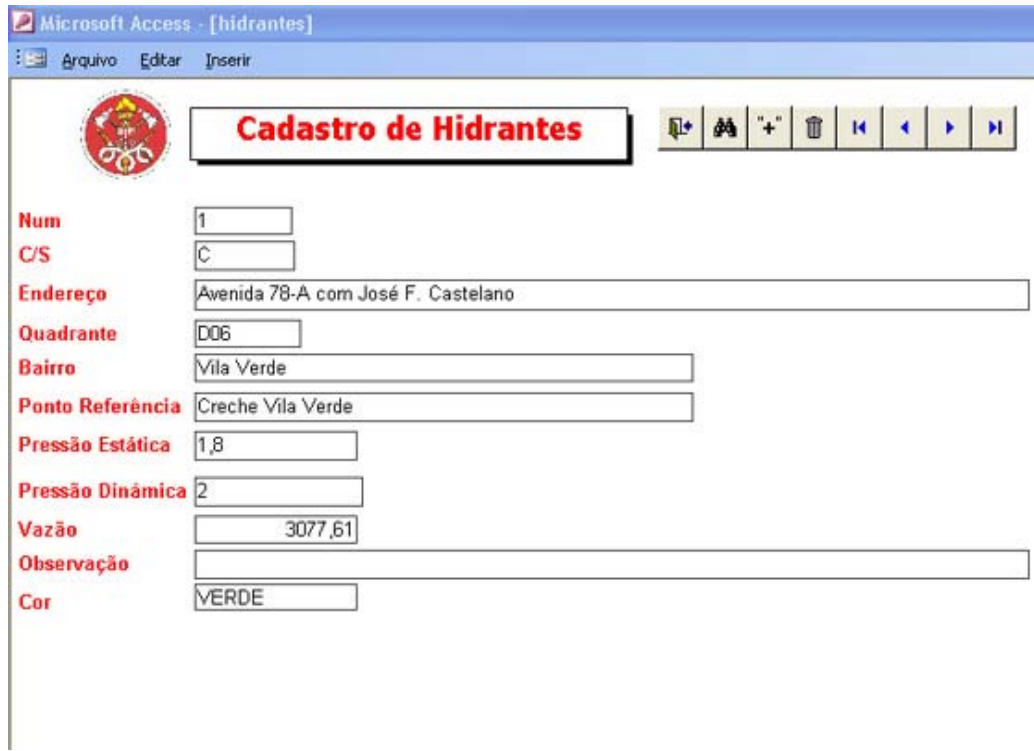

Figura 6 - Tela de Cadastro de Hidrantes

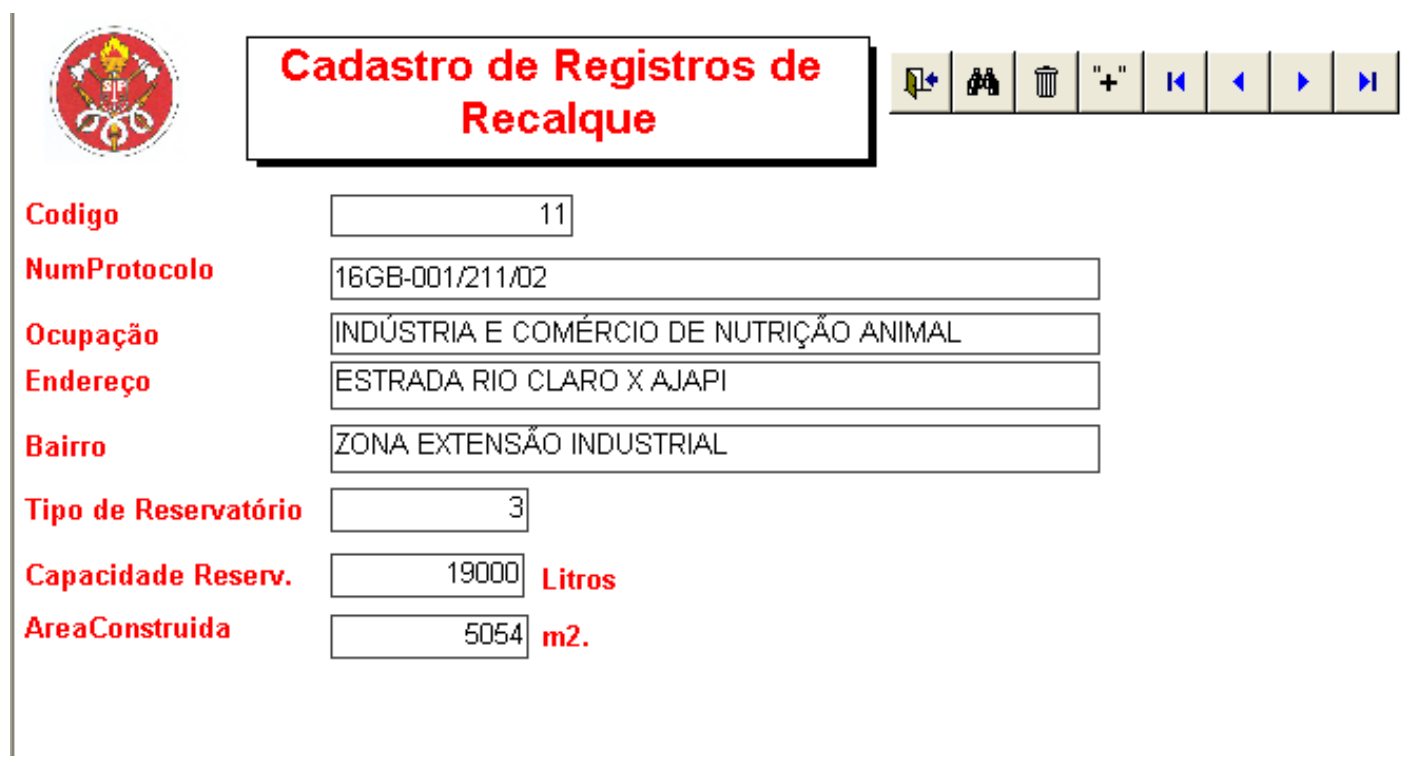

Figura 7 - tela de Cadastro dos Registros de Recalque

Ao lado do título de cada tela existem oito botões com as seguintes funções:

1. Sair da tela de cadastro

2. Localizar um registro

3. Adicionar um registro

4. Excluir um registro

5. Ir para o primeiro registro 
6. Ir para o registro anterior

7. Ir para o próximo registro

8. Ir para o último registro.

\subsection{Projeto Piloto}

Após a inclusão dos hidrantes no banco de dados, a próxima etapa foi montar o projeto piloto.

O projeto piloto tem como objetivo simular o uso do sistema. No projeto piloto foi usado o mapa já corrigido. Nele, foram introduzidos parte dos hidrantes e realizadas algumas consultas, como por exemplo, a consulta a hidrantes por bairro, ou a consulta de hidrantes por cor.

Estes dois tipos de consultas foram consideradas pelos bombeiros entrevistados como as mais importantes e foram as primeiras a serem testadas no sistema.

Os hidrantes foram identificados com um círculo na sua respectiva cor e dentro do círculo foi colocado o número de identificação do hidrante. Cada tipo de hidrante (amarelo, verde e vermelho) foi colocado em uma camada distinta.

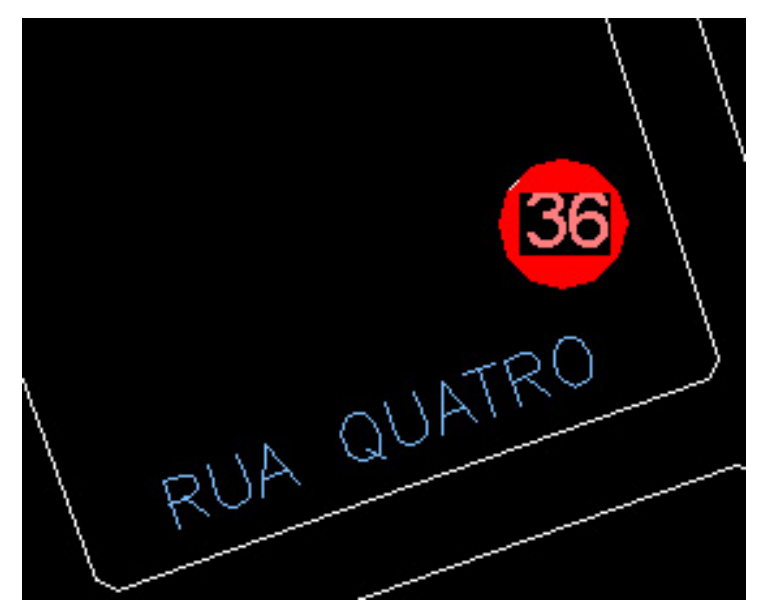

Figura 8 - Representação de um Hidrante no Mapa

Após a inserção do círculo representando o hidrante este deve ser associado a um registro no banco de dados. Este procedimento está detalhado no apêndice 
B desta dissertação. O treinamento aos bombeiros inclui o ensino deste procedimento.

Assim que a primeira versão do projeto piloto foi concluída ela foi apresentada à direção do posto de bombeiros e também ao bombeiro do NAT para avaliação.

O projeto piloto ajudou a mostrar para os bombeiros do posto envolvidos no projeto a viabilidade do sistema. Nesta etapa foram colhidas as primeiras impressões do sistema e as possíveis dificuldades que os usuários teriam em manuseá-lo. Foi identificada a necessidade de algumas mudanças, como por exemplo, a padronização no uso dos nomes dos bairros, o que gerou certa confusão no momento das consultas. Na lista de hidrantes fornecida pelo posto havia bairros identificados como Jardim Panorama e outros identificados como Jd. Brasília. Ou seja, os nomes dos bairros não estavam seguindo um padrão no cadastro.

Este problema foi solucionado em conjunto com os bombeiros que definiram a melhor maneira de identificar os bairros da cidade.

A identificação dos registros de recalque é semelhante ao hidrante. Foi atribuída a cor ciano para os registros e foi colocado ao lado do número do registro de recalque a letra "R" para diferenciá-lo do hidrante.

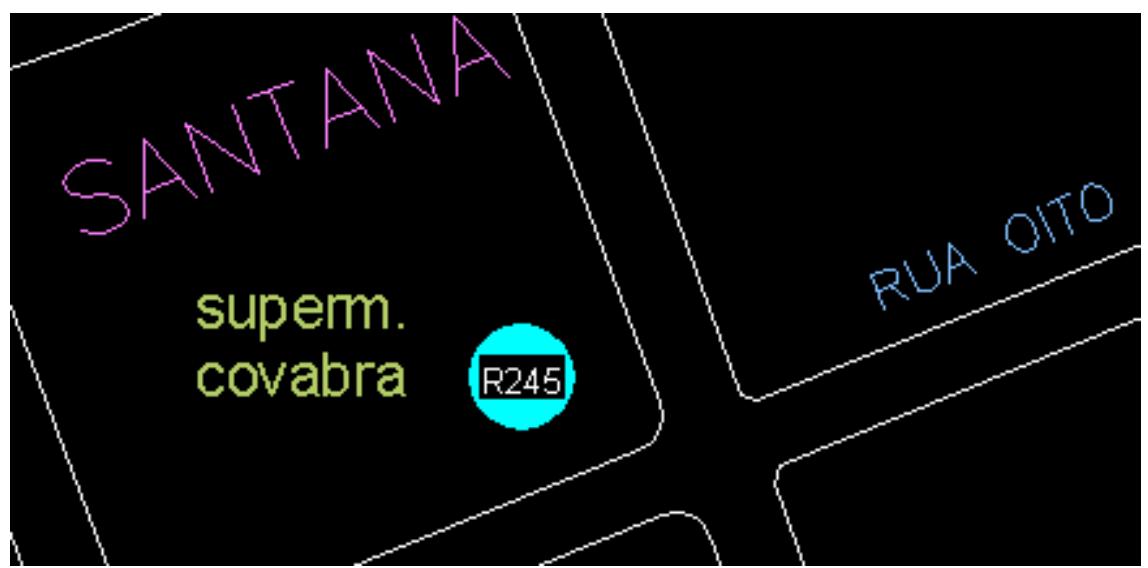

Figura 9 - Representação dos Registros de Recalque no Mapa

O resultado do projeto piloto foi satisfatório. Com ele foi possível determinar quais as melhorias que deveriam ser feitas em relação a sua interface. Foi possível também avaliar quais as principais dificuldades que os bombeiros 
tinham na utilização do sistema e determinar como seria feito o treinamento para que eles pudessem utilizar o sistema plenamente

\subsection{Consultas ao mapa}

Segundo Câmara et al. (1996) as linguagens de consultas à banco de dados geográficos podem ser classificadas em:

1. Textuais: que usualmente utilizam extensões SQL que acomodam relacionamentos espaciais;

2. Visuais: que utilizam a manipulação direta de elementos visualizados;

3. Multimodais: permitindo uma combinação de linguagem textual e interação via mouse na tela.

O sistema proposto pela presente pesquisa utiliza a forma multimodal de consulta ao mapa, já que o usuário pode realizar a busca por um ponto de abastecimento através de um critério em SQL que neste caso é informado através de uma janela e também pode utilizar o mouse para selecionar um ponto de abastecimento e obter informações sobre este ponto.

A forma como são realizadas as consultas no sistema estão apresentadas no apêndice B desta dissertação.

\subsection{Interface}

O termo interface é aplicado normalmente àquilo que interliga dois sistemas. Segundo Delazari (2004), a interface pode ser considerada tanto um meio para a interação usuário-sistema, quanto uma ferramenta que oferece os instrumentos para permitir e facilitar este processo comunicativo. Desta forma a interface é um sistema de comunicação. A interface possui componentes de hardware e software, os componentes de hardware são, por exemplo, a tela, o teclado e o mouse. O software da interface é a parte do sistema responsável pelos processos computacionais. O usuário interage com a interface e faz interpretações sobre as respostas fornecidas por esta.

O sistema proposto nesta pesquisa utiliza três tipos de interface: 
Interface de linguagem de comando: permite ao usuário fornecer instruções diretamente ao sistema por meio de comandos específicos. A interface da linguagem de comando é flexível, mas necessita que o usuário aprenda a linguagem e memorize os comandos. Esta memorização ocorre de forma natural quando se trabalha no dia a dia com o sistema.

Interface de preenchimento de formulários (ou quadros de diálogos): este tipo de interface apresenta um conjunto de campo a serem preenchidos, sendo eficiente para entrada e recuperação de informações específicas. As interfaces por formulários auxiliam o usuário na construção de comandos corretos, uma vez que todas as opções são listadas no quadro.

Interface de seleção de menus: fornecem ao usuário alguns comandos sob a forma de menus ou listas. A seleção de menus segundo Delazari (2004) reduz a flexibilidade por limitar as opções a um número pré-definido de escolhas, ao mesmo tempo em que evita escolhas erradas ou inviáveis.

A interface do Autocad Map teve a barra de ferramentas e a barra de menus modificada para facilitar o trabalho do usuário. Ainda para Delazari (2004) deve-se reduzir ao mínimo as opções que o usuário deve escolher. A utilização de janelas ou menus intermediários aumenta a complexidade e confusão dos usuários. Somente devem ser incluídos objetos que sejam necessários e relevantes para a aplicação.

O Autocad Map não permite a customização de quadros de diálogo, mas como qualquer software, tem a capacidade de prevenir que o usuário possa realizar uma tarefa inapropriada.

\subsection{Treinamento}

Após a conclusão do projeto piloto, a próxima etapa foi planejar o treinamento do pessoal envolvido. Este treinamento foi dividido em quatro etapas:

A. Treinamento básico: com o objetivo de apresentar os principais recursos do software. 
B. Treinamento de consultas a dados I: voltado aos bombeiros que trabalham no atendimento telefônico.

C. Treinamento avançado: voltado para o bombeiro do NAT responsável pela manutenção e atualização do mapa;

D. Treinamento de consultas a dados II: voltado aos bombeiros que trabalham no atendimento telefônico.

\subsubsection{Etapa A - Treinamento Básico}

O treinamento básico foi aplicado ao bombeiro do NAT responsável pelo sistema. Em um encontro junto à direção do posto ficou definido que o sistema teria um responsável por sua manutenção e atualização, enquanto os bombeiros responsáveis pelo atendimento telefônico receberiam treinamento somente para realizar as consultas no mapa.

Foram três os principais motivos que levaram a esta decisão:

1. Os bombeiros do atendimento telefônico não têm muito domínio do computador;

2. Realizar um treinamento completo do sistema com todas as pessoas envolvidas seria inviável, já que os bombeiros do atendimento trabalham em turno. $O$ treinamento seria muito longo e atrapalharia o andamento do trabalho diário dentro do posto.

3. Em conjunto com a direção do posto, constatou-se que não há necessidade dos bombeiros do atendimento telefônico aprenderem a fazer alteração no mapa, já que isto será uma atividade que será feita ocasionalmente.

Para realização do treinamento foi montado um cronograma e todo andamento do mesmo foi registrado em um diário de pesquisa. Este diário de pesquisa faz parte do apêndice $C$.

O conteúdo do treinamento desta etapa faz parte do apêndice A desta dissertação. 
O treinamento foi realizado em sete encontros de duas horas. Os encontros tiveram o intervalo de uma semana. Assim o bombeiro do NAT teve uma semana para exercitar o que foi aprendido.

\subsubsection{Etapa B - Treinamento de consulta a dados}

Esta segunda etapa do treinamento foi aplicada ao bombeiro do NAT como também aos quatro bombeiros que trabalham no atendimento telefônico.

Como cada bombeiro trabalha em horários diferentes, o treinamento foi individual e constituiu-se basicamente em mostrar como realizar consultas no mapa. Cada bombeiro recebeu um treinamento de duas horas nesta etapa do projeto.

Este primeiro contato com os bombeiros do atendimento telefônico com o sistema foi importante para aperfeiçoar a quarta e última etapa do treinamento da qual eles fizeram parte.

O conteúdo deste treinamento está no apêndice B desta dissertação.

\subsubsection{Etapa C - Terceira etapa do treinamento}

A terceira etapa do treinamento foi aplicada ao bombeiro do NAT que ficou responsável pela atualização do sistema.

O objetivo deste treinamento foi mostrar como é incluído um novo ponto de abastecimento no mapa e como ele deve ser associado ao registro do banco de dados.

Este treinamento foi realizado em dois encontros de duas horas com intervalo de uma semana. $O$ apêndice $A$ desta dissertação apresenta o conteúdo da terceira etapa do treinamento.

\subsubsection{Etapa D - Quarta etapa do treinamento}

Esta etapa do treinamento foi aplicada aos bombeiros que trabalham no atendimento telefônico. Nesta etapa o mapa já está pronto com todos os pontos de abastecimento cadastrados, inclusive os registros de recalque. 
Foi feita uma revisão do que foi visto no primeiro encontro com estes bombeiros e também algumas outras formas de consultas. Cada bombeiro teve um treinamento individual de duas horas para aprender a manusear o sistema.

\subsection{Migração do projeto piloto para o sistema final}

Nesta etapa foram incluídos todos os hidrantes no mapa e iniciou-se o trabalho de incluir os registros de recalque. Este trabalho foi mais demorado pois a inclusão do registro de recalque depende da filtragem de dados do programa SICAT, por este motivo foi deixado para ser realizado após os testes do projeto piloto.

\subsection{Implantação do sistema final}

Após instalação do hardware e do software, o sistema foi instalado no setor de atendimento telefônico do posto. Com o computador no local adequado, foi realizado a quarta etapa do treinamento que consistiu em ensinar aos bombeiros do atendimento como se faz as consultas ao mapa.

\subsection{Monitoramento}

Esta etapa do projeto procurou verificar o que foi assimilado durante todo o treinamento. Visitas ao posto de bombeiros foram agendadas para tirar eventuais dúvidas com relação ao uso do sistema. 


\section{Conclusão}

A presente dissertação buscou através da pesquisa-ação observar os aspectos que envolvem a implantação de um Sistema de Informação Geográfica para localização de pontos de abastecimento. Durante a implantação deste sistema puderam ser observadas quais as características mais relevantes que eles devem possuir.

O sistema de informação geográfica implantado no posto de bombeiros do município de Rio Claro pode ser considerado como um sistema de apoio à decisão. Os resultados obtidos após o treinamento dos bombeiros permitiu verificar que o sistema pode agilizar a localização de vários pontos de abastecimento e ajudar o bombeiro decidir qual o melhor local para abastecimento da viatura quando estiver atendendo uma ocorrência de incêndio.

A seleção de alternativas é onde o sistema de apoio a decisão pode vir a ser útil. Assim que uma alternativa for selecionada, várias ações serão disparadas na organização para resolver o problema. (neste caso, encontrar um ponto de abastecimento).

Durante a interação com o posto de bombeiros, foi possível amadurecer o trabalho de pesquisa. Com a pesquisa-ação foi percebida a possibilidade de criar conhecimento dentro da organização. Este conhecimento pode ser utilizado para melhorar o trabalho do corpo de bombeiros. Além disso, permite que os próprios bombeiros possam gerenciar este sistema. Através do trabalho diário neste sistema eles podem se tornar auto-suficientes no uso desta tecnologia.

Esta pesquisa permitiu concluir ainda que:

É possível criar um Sistema de Informação Geográfica que seja de fácil manuseio por parte dos bombeiros. Os próprios bombeiros através de treinamento adequado podem criar e gerenciar este tipo de sistema. 
Outras funcionalidades podem ser incorporadas a este sistema. Podem ser criadas as rotas para indicar o melhor caminho que a viatura tem que usar para realizar o abastecimento.

O mapa no formato digital pode ser utilizado para localizar endereços no município e pode vir a ser útil em outras situações como o atendimento a vítimas de trânsito.

É possível também criar mapas temáticos para auxiliar a identificação de áreas que possuem pouca cobertura dos pontos de abastecimento. Mapas temáticos podem ser criados para indicar também as áreas de risco dentro do município.

Com relação à implantação do sistema no posto de bombeiros foi possível concluir que alguns bombeiros têm mais dificuldade na utilização do computador do que outros. O treinamento efetuado procurou eliminar estas dificuldades e fazer com que os usuários comecem a utilizar o mapa digital com mais freqüência, deixando de usar o mapa impresso. Remover o mapa impresso da sala de atendimento faria com que os bombeiros utilizassem somente o mapa digital, mas seria necessário que todo o posto recebesse o treinamento.

O que se verificou durante o levantamento bibliográfico é que existem poucos trabalhos que tratam detalhadamente da implantação de um Sistema de Informação Geográfica. A maioria apresenta apenas o que foi implantado e os benefícios alcançados. O presente trabalho procurou preencher esta lacuna existente na literatura.

Com relação aos métodos estudados, foi possível concluir que a metodologia de Huxhold procura apresentar o planejamento da implantação e preocupa-se com o desenvolvimento de uma visão conceitual de todos os participantes. Sendo que com ela todos os participantes podem conhecer os benefícios do SIG. Huxhold mostra que se deve trabalhar o fato de que o sistema irá modificar a rotina de trabalho dos participantes.

Do plano de partida proposto por Huxhold foi possível aprender que a utilização de um cronograma de trabalho auxilia o desenvolvimento do projeto e permite 
que os participantes da ação se tornem mais comprometidos com o pesquisador.

A metodologia de Clarke teve como principal contribuição a criação do estudo piloto que foi utilizado neste projeto de pesquisa.

Alguns passos destas metodologias não foram utilizados:

Huxhold, procura mostrar a importância da criação de equipes e a definição dos papéis dos participantes. Neste projeto isto foi feito, mas em uma escala muito menor do que supõe a metodologia do autor, já que o número de participantes é pequeno.

Clarke, por sua vez enfatiza a avaliação de vários sistemas, e a execução de testes de desempenho antes da escolha de um sistema definitivo. Neste projeto apenas um sistema foi estudado. Não houve tempo e recursos suficientes para analisar vários sistemas.

Com isso, foi possível perceber que estas metodologias são voltadas para sistemas de informação geográfica de porte maior, que envolvem muitas pessoas e vários fornecedores. Hoje os SIG's estão mais populares no mercado tendo inclusive aplicações gratuitas e podem ser implantados em pequenas organizações. Estas organizações podem, por sua vez criar aplicações pouco complexas e dela obter resultados satisfatórios.

A principal vantagem destas tecnologias foi a descrição das etapas a serem cumpridas durante o planejamento e implantação do sistema. Elas podem ser adaptadas a um sistema de informação geográfica mesmo que seja de pequeno porte. 


\section{Referências}

ALTER, S. (2003). A work system view of DSS in this fourth decade. San Franciso: Scholl Of Bussiness and Management, Universty of San Francisco.

AMARAL, D.C. (2001). Arquitetura para gerenciamento de conhecimentos explícitos sobre processo de desenvolvimento de produto. 214p. Tese (Doutorado) - Escola de Engenharia de São Carlos, Universidade de São Paulo, São Carlos, 2001.

ARONOFF, S. (1989). Geographical information system: a management perspective. Ottawa: WDL.

BEYLER, C.L. (2001). Fire safety challenges in the 21st century. Journal of Fire Protection Engineering, v.11, p.4-15, Fev.

BIRKS, D.F.; NASIRIN, S.; ZAILANI S.H.M. (2003). Factors influencing GIS project implementation failure in the UK retailing industry. International Journal of Information Management, Amsterdam, v.23, n.1, p.73-82, Fev.

BISPO, C.A. F. (1998). Uma análise da nova geração de sistemas de apoio a decisão. 144p. Dissertação (Mestrado) - Escola de Engenharia de São Carlos, Universidade de São Paulo, São Carlos, 1998.

BRASIL. Constituição (1988). Constituição da República Federativa do Brasil. Brasília, DF: Senado.

BUDIC. Z.D.; GODSCHALK, D.R. (1994). Implementation and management effectiveness in adoption of GIS technology in local governments. Computers, Environment and Urban Sytems,Amsterdam, v.18, n.5, p.285-304, Sept./Oct.

CÂMARA, G.; DAVIS CLODOVEU, M.A.M. (2004a). Introdução à ciência da geoinformação. São José .dos Campos: INPE.

CÂMARA, G. et al. (1996). Anatomia de sistemas de informação geográfica. Escola de Computação; SBC.

(2004b). Análise espacial e geoprocessamento. Brasília: EMBRAPA.

CLARKE, A.L. (1991). GIS especification, evaluation and implementation. In: MAGUIRE, D.J.; GOODCHILD, M.; RHINDS, D.W. Geographic Information systems: principles and aplication. New York: John Willey.

CONCEITOS básicos de proteção contra incêndios. (2001). São Paulo: Corpo de Bombeiros do Estado de São Paulo. (Instrução técnica, 2).

CORPO DE BOMBEIROS DO ESTADO DE SÃO PAULO (2004). História do corpo de bombeiros. Disponível em:<http://www.ccb.polmil.sp.gov.br>. Acesso em: 5 set. 2004 . 
COUGHLAN, P.; COUGHLAN, D. (2002). Action research for operation management. Internacional Journal of Operations \& Production Management, Bradford, v.22, n.2, p.220-240.

COX, G. (1999). Fire research in 21st century. Fire Safety Journal, Amsterdam, n.32, n.3, p.203-219, Apr.

DE NOVO e muito pior. (1974). Folha de São Paulo, São Paulo, 1 fev. Disponível em:<http://www1.folha.uol.com.br/folha/arquivos/>. Acesso em: 20 set. 2004.

DELAZARI, L.S. (2004). Modelagem e implementação de um atlas eletrônico interativo utilizando métodos de visualização cartográfica. 155p. Tese (Doutorado) - Escola Politécnica, Universidade de São Paulo, São Paulo, 2004.

EGENHOFER, M.J. et.al. (1999). Progress in computational methods for representing geographical concepts. Geogrpahical Information Science, v.13, n.8, p.775-776.

FERRARI, R. (1997). Viagem ao SIG: planejamento estratégico, viabilização, implantação e gerenciamento de sistemas de informação geográfica. Curitiba: Sagres.

FIRE ENGINEERING (1997). 120 Years retrospective. Tulsa, n.2, p.57-61, Fev.

FLICK, U. (2004). Uma introdução à pesquisa qualitativa. 2.ed. São Paulo: Bookman.

FREITAS, I.A.; ANDRADE, J.E.B. ( 2004). Efeitos de treinamento nos desempenhos individual e organizacional. Revista de Administração de Empresas - RAE, São Paulo, v.44, n.3, p.44-56.

GIL, A.C. (1999). Métodos e técnicas de pesquisa social. São Paulo: Atlas.

GODOY, A.S. (1995). Introdução à pesquisa qualitativa e suas possibilidades. Revista de Administração de Empresas - RAE, São Paulo, v.35, n.2, p.57-63.

GÓES, K. (2000). Autocad Map explorando as ferramentas de mapeamento. Rio de Janeiro: Ciência Moderna.

GUMMESSON, E. (2000). Qualitative methods in management research. 2nded. Thousand Oaks: Sage.

HIDRANTES de coluna. (2001). São Paulo: Corpo de Bombeiros do Estado de São Paulo. (Instrução técnica, 34).

HUXHOLD, W.E.; LEVINSHON, A.G. (1995). Managind geographic information projects. Oxford: University Press.

INCÊNDIO da indústria Vila Velha, Rio Claro 15 de julho de 1994. (1994). Rio Claro: Posto de Bombeiros, 1994. (Relatório de ocorrência). 
INSTITUTO BRASILEIRO DE GEOGRAFIA E ESTATÍSTICA (2004). Telefones instalados, segundo as unidades da federação. Disponível em:<http://www.ibge.gov.br>. Acesso em: 25 set. 2004.

. (2004a). População das capitais dos estados do Brasil (1872, 1890, 1900 e 1910). Disponível em:<http://www.ibge.gov.br>. Acesso em: 25 set. 2004.

JENNINGS, C.R. (1999). Socioeconomic characteristics and their relationship to fire incidence: a review of the literature. Fire Technology, v.35, n.1, p.7-29.

DAVIS JUNIOR, C.A. (2000). Múltiplas representações em sistemas de informação geográfico. 106P. Tese (Doutorado) - Instituto de Ciências Exatas, Universidade Federal de Minas Gerais, Belo Horizonte, 2000.

KORTE, G.B. (2001). The GIS book. Albany: Thomson Learning:. Albany. LAKATOS, E.M.; MARCONI, M.A. (1991). Fundamentos de metodologia científica. 3.ed. São Paulo: Atlas.

LAUDON, K.C.; LAUDON, J.P. (1999). Sistemas de informação. Rio de Janeiro: LTC.

MAGUIRE, D.J.; GOODCHILD, M.; RHINDS, D.W. (1991). Geographic Information systems: principles and aplication. New York: John Willey.

MANUAL de fundamentos do corpo de bombeiros: abastecimento. (1997a). São Paulo: Corpo de Bombeiros do Estado de São Paulo. v.6.

MANUAL de fundamentos do corpo de bombeiros: comunicações. (1997b). São Paulo: Corpo de Bombeiros do Estado de São Paulo. v.11.

MANUAL de fundamentos do corpo de bombeiros: técnicas de extinção de incêndio. (1997c). São Paulo: Corpo de Bombeiros do Estado de São Paulo. v.14.

MARAKAS, G.M. (1999). Decision support systems in the twenty-first century. New Jersey: Prentice Hall.

MARTINS, G.A. (1995). Epistemologia da pesquisa em administração. 110p. Tese (Livre-docência) - Faculdade de Economia,m Administração e Contabilidade, Universidade de São Paulo, São Paulo, 1995.

McGEE, J.; PRUSAK, L. (1994). Gerenciamento estratégico da informação. Rio de Janeiro: Campus.

MENEGUETTE, A. (2001). Courseware em ciências cartográficas. Disponível em:<http://www.multimidia.prudente.unesp.br/arlete/hp_arlete/courseware/cour se.htm\#icm>. Acesso em: 10 jan. 2005.

MILLER, M.B.; GREENWOOD, D.; MAGUIRE, P. (2003). Why action research? Thousand Oaks: Sage. v.1, p.9-28. 
MITREN - Sistemas e Montagens Veiculares (2004). Catálogo de produtos. Santa Cruz do Sul.

NASIRIN, S.; BIRKS, D.F. (2003). DSS implementation in UK retail organisations: a GIS perspective. Information and Management, Amsterdam, v.40, n.4, p.325-336, Mar.

O'BRIEN, J.A. (2003). Sistemas de informação e as decisões gerenciais na era da Internet. 9.ed. São Paulo:Saraiva.

ORMEROD, R.J. (1996). Combinig management consultancy and research. Woarwick Bussines Scholl, Coventry, v.24, n.21, p.1-12.

PIDD, M. (1998). Modelagem empresarial: ferramentas para tomada de decisões. Porto Alegre: Bookman.

POWER, D. (1997). A brief history of decision support systems. Disponível em:<http://www.dssresources.com/history/dsshistory.html>. Acesso em: 23 Nov.2004.

REVISTA DO CORPO DE BOMBEIROS (2002). Marília. Edição comemorativa do $16^{\circ}$ grupamento de bombeiros.

RODRIGUES, J. (1994). Tragédias mudam legislação sobre incêndio. Folha de São Paulo, São Paulo, 30 jan. 1994. Caderno Cotidiano, p.4. Disponível em:<http://www1.folha.uol.com.br/folha/arquivos/>. Acesso em: 20 set. 2004.

ROSSETI, L.A.F.G; OLIVETTI, G.S. (2003). Autodesk Map 5. Rio Claro: UNESP.

SÃO PAULO (1974). Lei nº 616 de 17 de dezembro de 1974, que dispõe sobre a estrutura, competência, deveres e direitos da Polícia Militar. Poder Legislativo, São Paulo, Artigo Segundo, Inciso V.

SEADE - Fundação Sistema Nacional de Análise de Dados (2004). Memória das estatísticas demográficas. Disponível em:<http://www.seade.gov.br>. Acesso em: 25 set. 2004.

SECRETARIA NACIONAL DE SEGURANÇA PÚBLICA. (2004). Conceitos básicos. Disponível em:<http://www.mj.gov.br/senasp/Default.htm>. Acesso em: 20 nov. 2004.

SHIM, J.P. et al. (2002). Past, present and future of decision support technology. Decision Support Systems, Amsterdam, v.33, n.2, p.111-126, June.

SILBERSCHATZ, A.K.; HENRY, F.; SUDARSHAN, S. (1999). Sistema de banco de dados. 3.ed. São Paulo. Makron Books.

THIOLLENT, M. (2000). Metodologia da pesquisa-ação. 10.ed. São Paulo: Cortez. 
THOMSON, C. (1997). Fire engineering: a 120 years old retrospective. Fire Engineering, v.150, n.2, p.57-61.

TURBAN, E.; ARONSON, J.E. (2001). Decision support systems and intelligent systems. 6thed. New Jersey: Prentice Hall.

WYBO, J.L. (1998). FMIS: A decision support system for forest fire prevention and fighting. IEEE Transactions on Engineering Managemt, New York, v.45, n.2, p.127-131. 
Apêndice A - Cronograma das aulas de Autocad Map Trabalhando com mapas 


\section{Objetivos:}

1. Aprender a usar o mapa da cidade com os pontos de abastecimento.

2. Aprender a criar sessões de trabalho para vincular o mapa.

3. Associar os registros do banco de dados ao ponto de abastecimento.

4. Incluir novos registros no banco de dados.

5. Incluir novos pontos de abastecimento e fazer a associação.

6. Realizar pesquisas no mapa.

\section{Criar uma sessão de trabalho}

Para realizar pesquisas e vincular dados aos objetos do mapa é necessário criar uma sessão de trabalho. Esta sessão pode ser gravada como um arquivo para uso posterior.

\section{Criando um Drive Set}

No menu Map $\rightarrow$ Define $\rightarrow$ Define/Modify Drawing Set

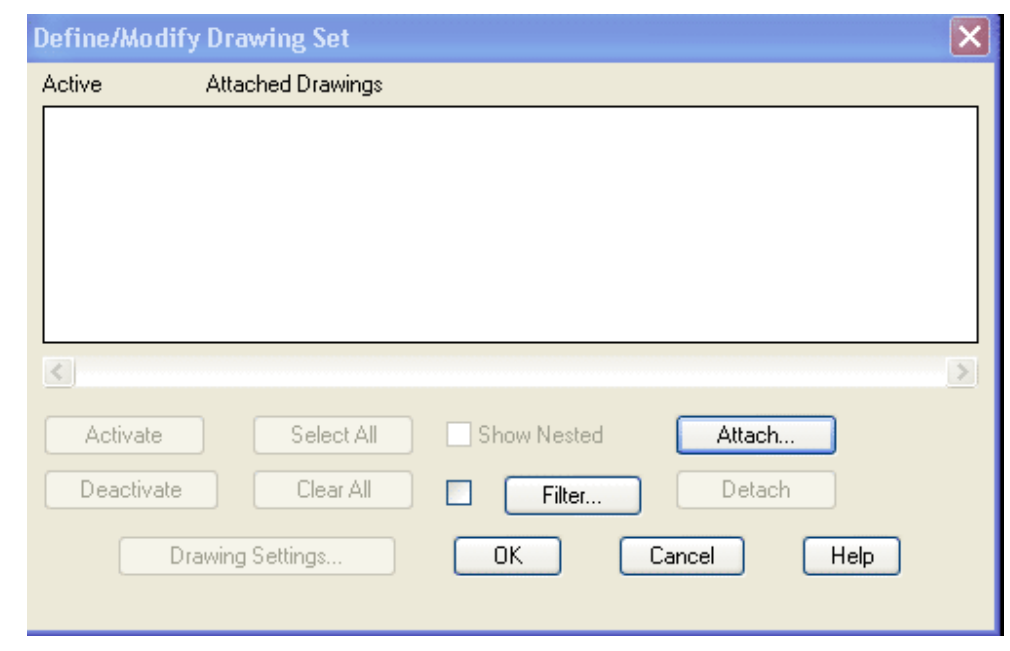

Em seguida clique no botão Attach.

No quadro seguinte, escolha o Alias do diretório desejado e em escolha o arquivo que deseja adicionar à sessão de trabalho. Clique em OK para confirmar.

Pronto. Veja no quadro Project o arquivo adicionado. 


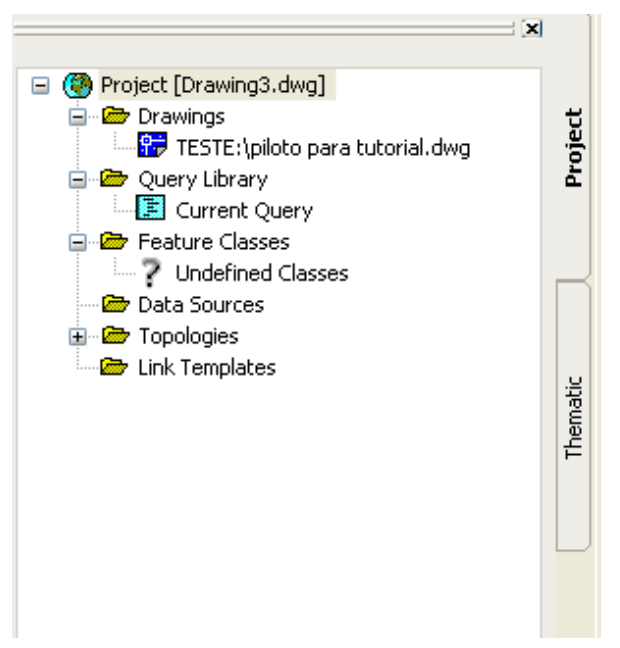

\section{Usando o Zoom Source Drawing}

Antes de executar a pesquisa, você precisará ajustar a visualização do projeto para juntar os projetos vinculados à sua sessão de trabalho.

Menu map $\rightarrow$ Drawings $\rightarrow$ Quick View Drawings. NO quadro, selecione o arquivo e clique em OK.

Menu Map $\rightarrow$ Drawings $\rightarrow$ Zoom Drawing Extents.

Se preferir, do quadro de projeto, clique o botão direito do mouse sobre o desenho e escolha estas opções.

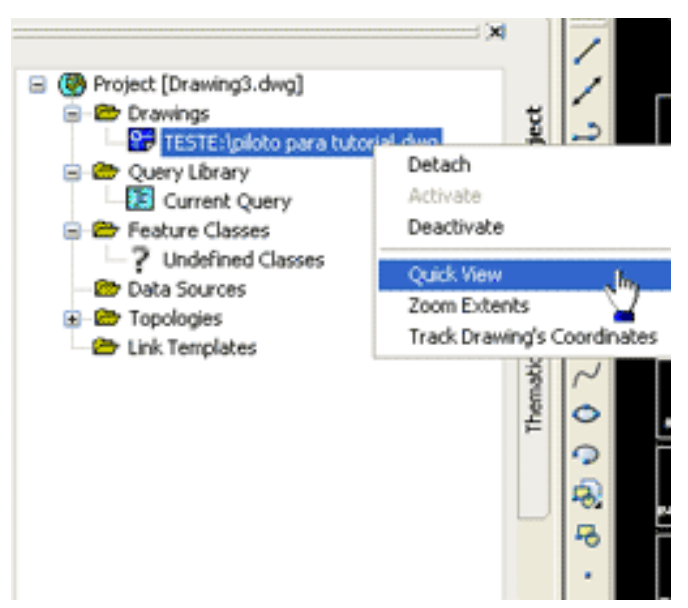


Através deste menu de atalho também é possível desvincular um mapa da sessão de trabalho através da opção Detach.

A opção Activate e Desactivate, ativam ou desativam o mapa para consulta. Sempre deixe-o ativado (como mostra a figura acima).

\section{Edição do mapa fonte}

Se pretende editar objetos que foram resgatados através de consultas e salválas para o desenho fonte (save back), você deve indicar as entidades que deseja salvar e adicioná-las ao save set ou salvá-las diretamente para o desenho fonte.

O processo de edição envolve o seguintes passos:

Usar uma ferramenta de pesquisa para resgatar para a sessão de trabalho entidades de mapas vinculados para edição. Depois, facão o seguinte: No menu Map $\rightarrow$ escolha Save Back $\rightarrow$ Add objects to save set então você especifica o grupo de entidades editadas que deseja salvar para o mapa fonte.

Modifique a entidade usando qualquer comando de edição. O Autocad entra no prompt do sistema e pergunta se você deseja adicionar as entidades para o Save set.

Obs:

- Se você configurou a opção Don't Add Objcts to Save Set, o Autocad Map não disponibiliza o prompt do sistema para você adicionar as entidades pesquisadas para o save set.

- Se você configurou a opção Add objects to save set without prompting, o Autocad Map adiciona as entidades pesquisadas para o save set automaticamente.

Estas opções podem ser ajustadas através do menu Map $\rightarrow$ Options $\rightarrow$ guia Save Back. 


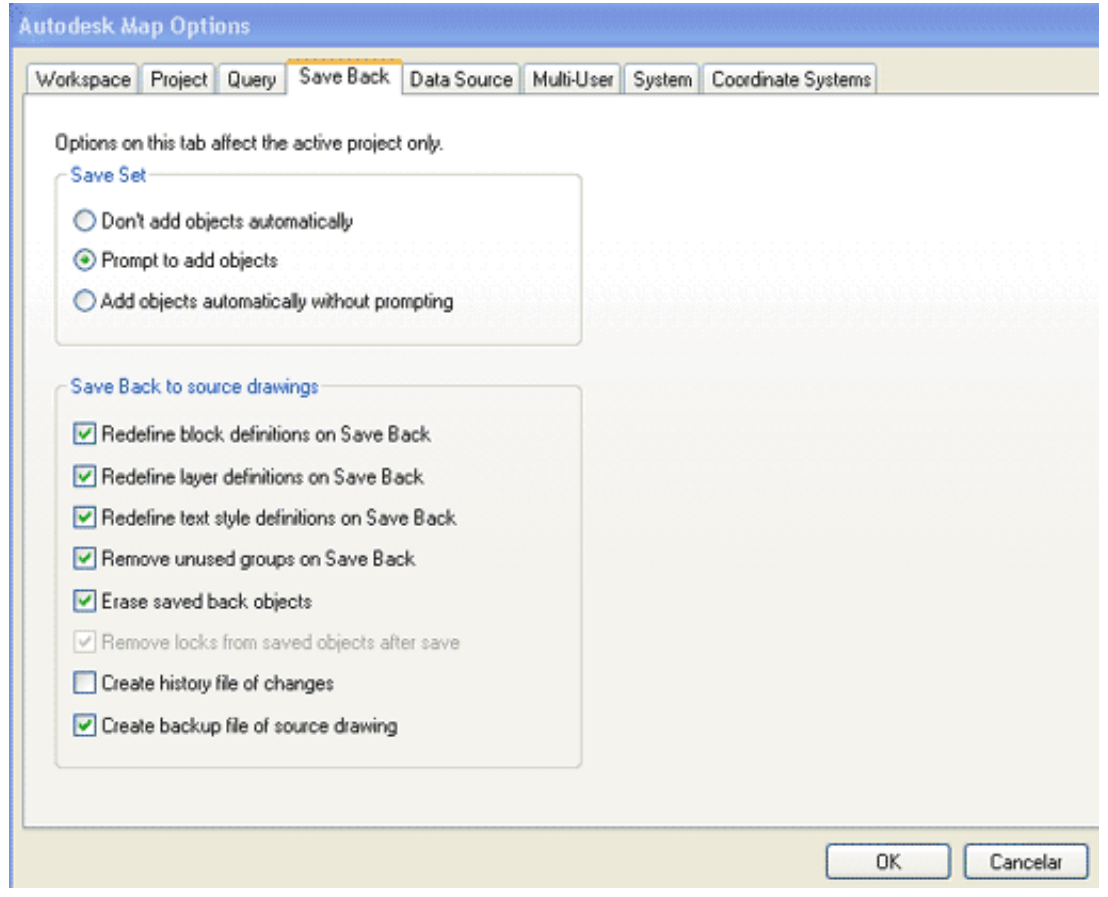

Para cancelar alterações, utilize o comando UNDO (Ctrl+Z) e no menu Map, escolha Save Back $\rightarrow$ remove objects from save set. 


\section{Edição do mapa}

Quanto você adiciona um mapa à sessão de trabalho e visualiza o mesmo, percebe que ao clicar no mapa, ele fica selecionado como um todo.

Para realizar edições no mapa e também alguns tipos de pesquisa, é necessário resgatar através de uma pesquisa todos os objetos deste mapa através de suas camadas.

Realize os seguintes passos:

Menu Map $\rightarrow$ Query $\rightarrow$ Define Query.

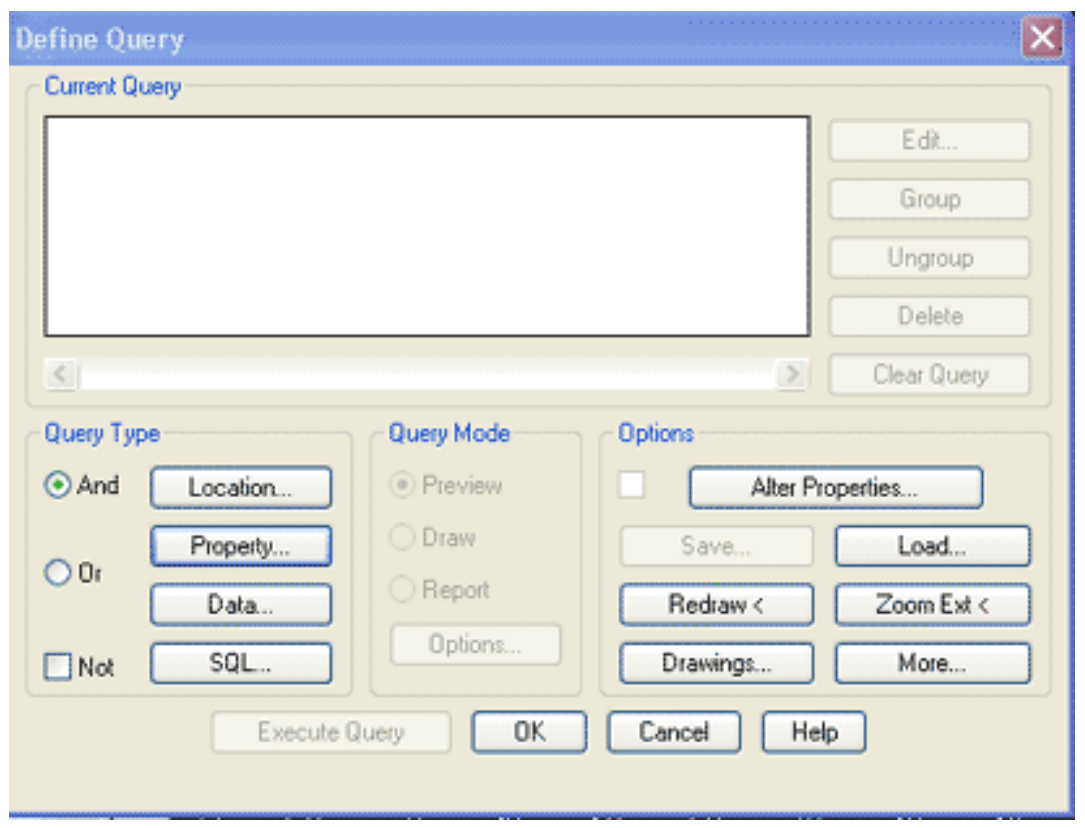

No quadro, clique no botão Property. Surge o seguinte quadro: 


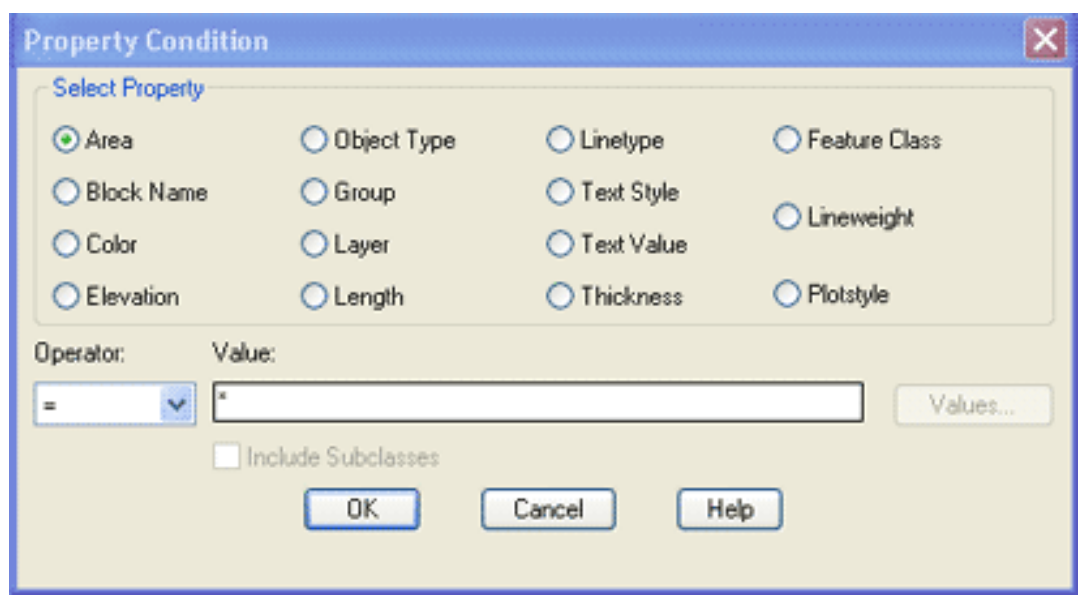

Nele, clique na opção Layer e depois clique no botão Values. Escolha todos os layers da lista e confirme em OK.

De volta ao quadro anterior, selecione a opção Draw e depois clique no botão Execute Query.

Observe que agora você pode selecionar os objetos individualmente.

\section{Realizando pesquisas}

Pesquisa é uma ferramenta usada para extrair de seus mapas exatamente a informação que você deseja.

Para executar uma pesquisa é necessário abrir um desenho novo e associar mapas fonte a sessão de trabalho. O Autocad Map não permite realizar pesquisas no mapa original como forma de proteção e evitar que mapas sejam danificados com edição imprópria.

Uma pesquisa se baseia em critérios. Quando você define uma pesquisa, define um critério para resgatar entidades. Os critérios podem ser:

- Locação (location)

- Propriedade (Property)

- Tabela do Autocad Map (object data)

- SQL baseado em um banco de dados vinculado a entidade usando tabelas do tipo (object data) e/ou usando dados linkados a entidades do desenho baseado em tabelas do tipo SQL. 


\section{Critérios}

Locação (location) usando este critério você pode por exemplo, recuperar todas as entidades de uma raio de 20 metros a partir de um certo ponto.

Os critérios disponíveis são:

\begin{tabular}{l|l} 
All & Point \\
Buffer fences & Polygon \\
Circle & Polyline \\
Fence & Window
\end{tabular}

Property (propriedade): usando como critério uma propriedade, voce pode recuperar entidades que estão em uma camada específica ou recuperar todas as entidades de um certo tipo de linha ou cor.

Os critérios disponíveis são:

Área

Color

Object type

Block name

Elevation

Group

Layer

Linetype

Textvalue

Lengh

Text style

Thickness 


\section{Executando a pesquisa}

Depois que você define uma pesquisa, pode executá-la no modo Preview, Draw e Report.

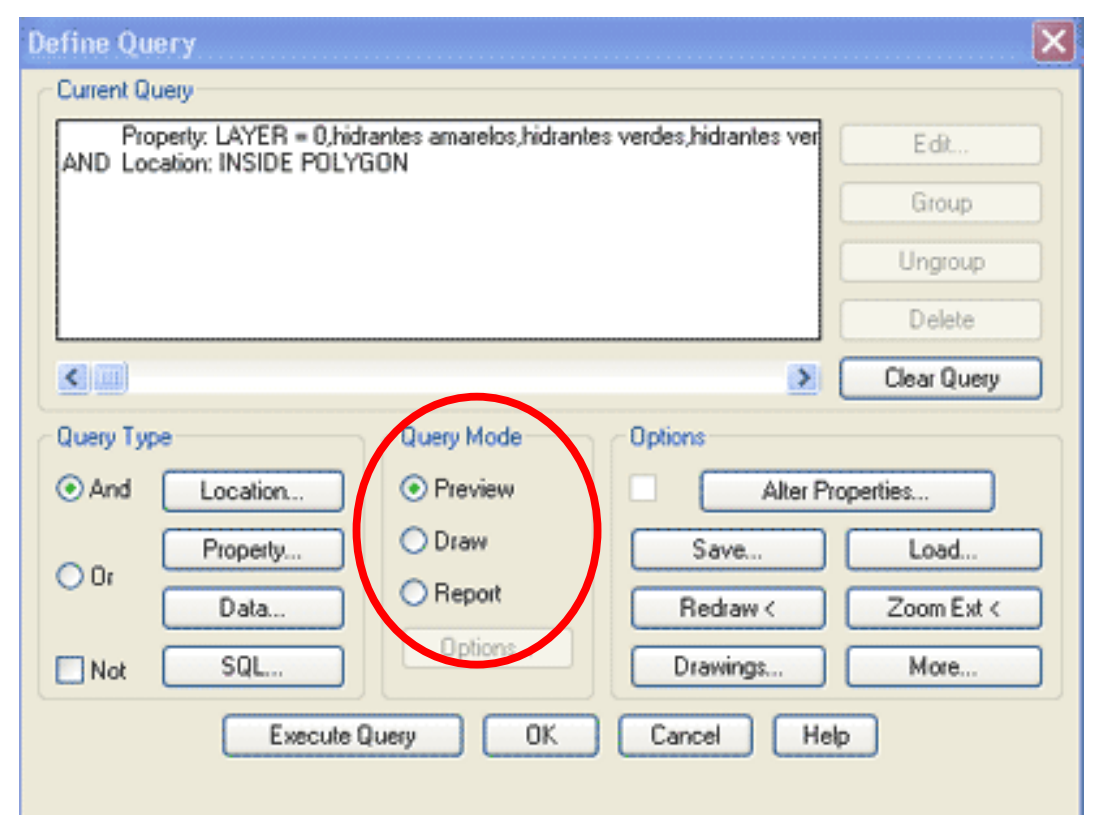

Preview - (visualização) - mostra previamente o resultado da pesquisa.

Draw - Traz na sessão de trabalho no desenho novo, o resultado da pesquisa.

Report - Gera um arquivo txt com o resultado da pesquisa.

Options - O relatório pode ser baseado em Data, SQL, Properties e Ranges.

\section{Como salvar pesquisas}

No quadro de diálogo Define Query, clique no botão Save... 


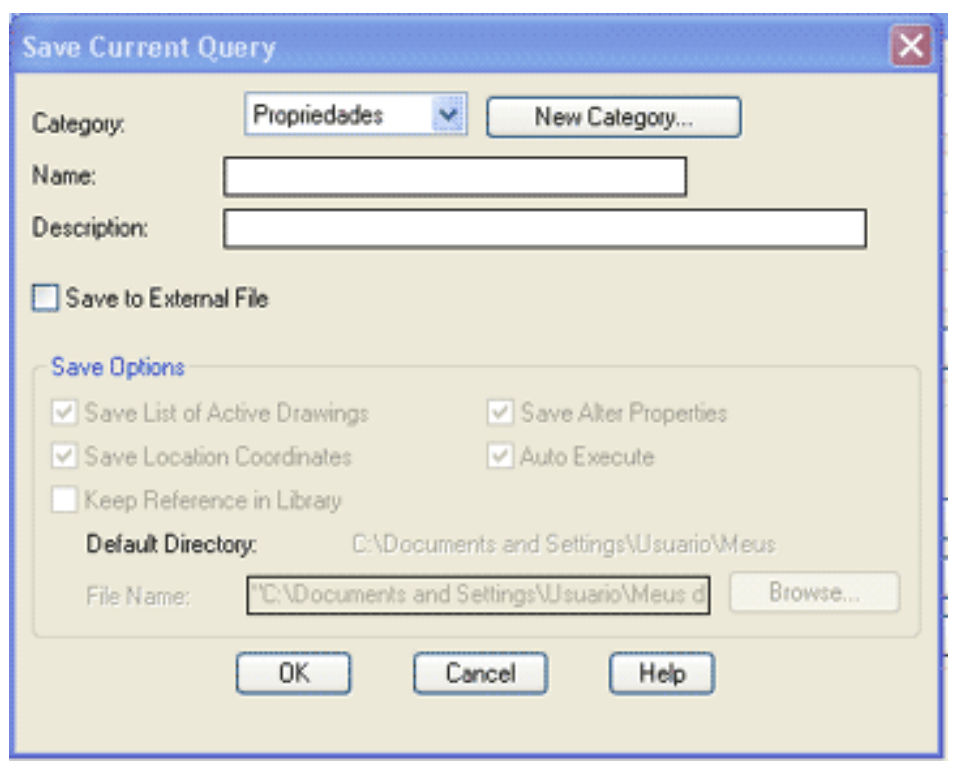

No quadro acima, escolha uma categoria ou então, crie uma nova usando o botão New Category...

Em seguida, determine um nome e uma descrição para a pesquisa nas caixas Name e Description.

Veja no Projetc Workspace (espaço do projeto) as pesquisas que foram salvas.

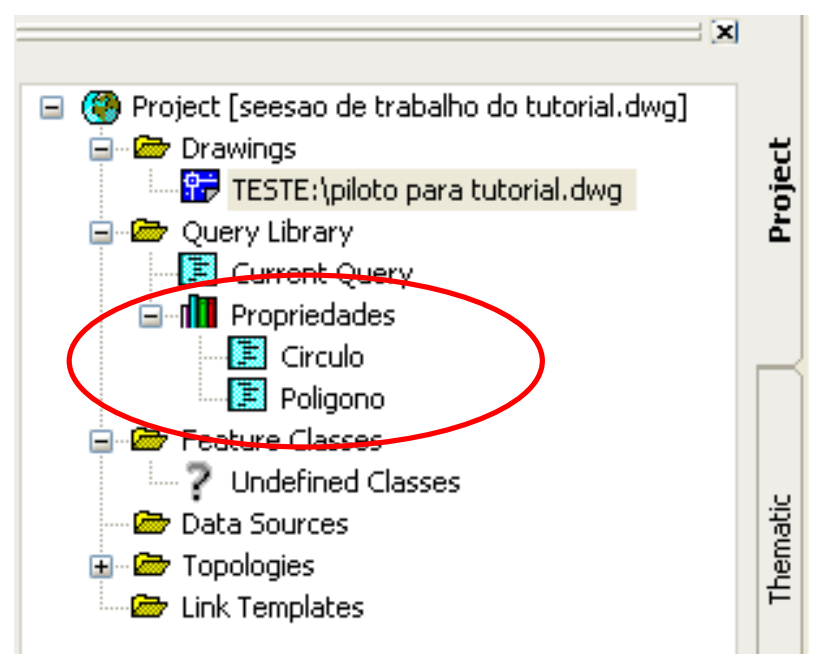

Clicando o botão direito do mouse sobre a pesquisa salva você pode executála, editá-la ou até mesmo apagá-la. 


\section{Usando banco de dados externo}

O Autocad Map utiliza o Autocad SQL Environment (ASE) para gerenciar o acesso a tabelas de banco de dados externos.

Este recurso estabelece links para as entidades e o banco de dados. Uma vez configurado você pode estabelecer, por exemplo, pesquisas baseadas em critérios de SQL.

O Autocad Map usa links para conectar entidades gráficas do mapa a informações no banco de dados.

O Link Path Name é a última da etapa de configuração de uma conexão de um banco de dados.

Link Path Name (LPN): consiste em um valor da coluna chave da tabela que está sendo usada para vincular registros de um banco de dados a entidades de um mapa, com objetivo de estabelecer a conexão entre entidades e tabela. $\mathrm{O}$ LPN é também um tipo de diretório alias usado para reter essas informações e fica armazenado na sessão de trabalho. 


\section{Como vincular um banco de dados}

No Project Workspace, clique o botão direito do mouse sobre o item Data sources e escolha a opção Attach

No quadro, encontre o arquivo desejado e escolha Attach.

Observe o banco de dados e suas respectivas tabelas no project workspace

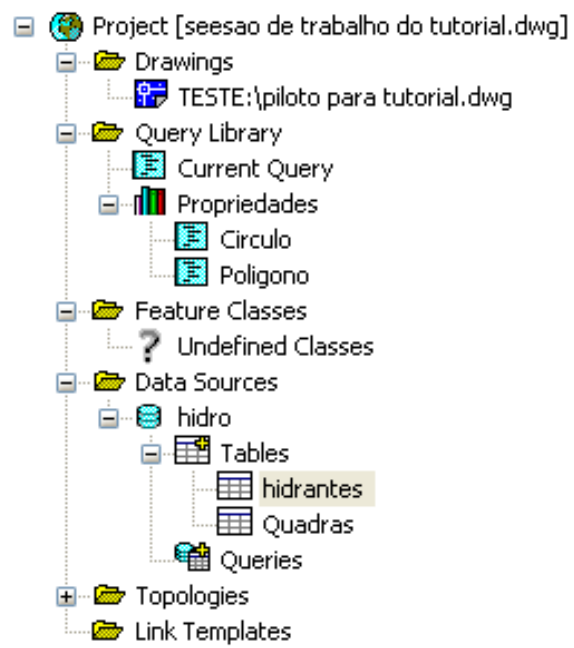

Visualizando informações com o Data View:

Após ter vinculado o banco de dados no seu mapa, você pode usar a ferramenta DataView para visualizar os seus dados. Para isso, basta clicar duas vezes sobre a tabela desejada no project workspace. 


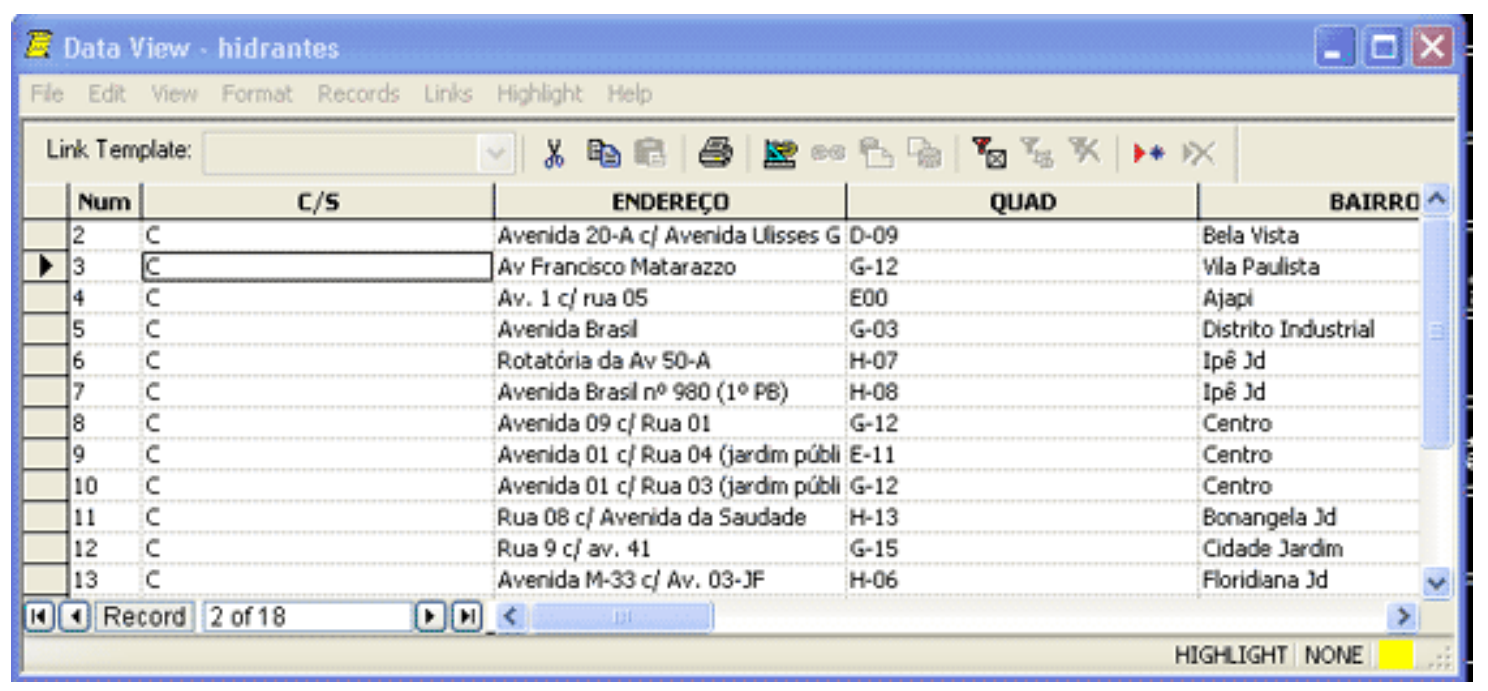

\section{Gerando os links}

Embora você possa manipular seus dados usando o DAtaView, é muito mais interessante trabalhar com a ferramenta DataView após ter feita a linkagem dos registros de banco de dados a entidades de desenho do mapa. A linkagem pode ser feita de maneira automática ou manual.

Antes de gerar os links entre as entidades e o banco de dados é necessário estabelecer a conexão entre a tabela de banco de dados e o mapa em que o LPN fica armazenado na sessão de trabalho.

\section{Como definir um Link Path Name (LPN)}

No project workspace, clique o botão direito do mouse no item link template e escolha link path name

Surge o seguinte quadro: 


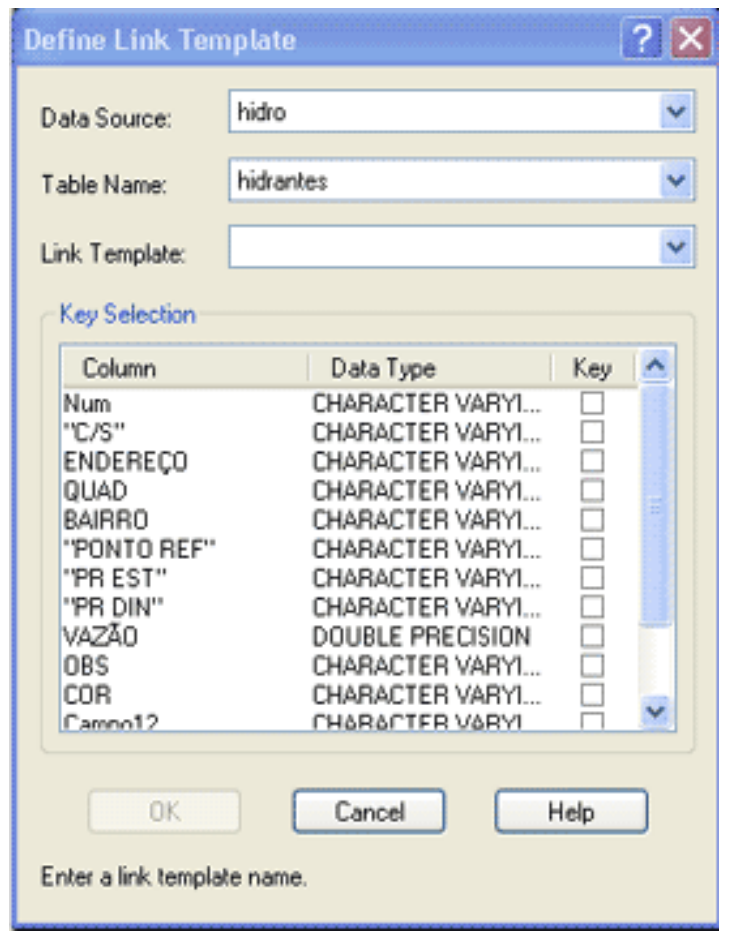

Neste quadro, indique a tabela que será usada e o nome do Link Template. Escolha qual campo possui a chave, ou seja qual campo não tem valores repetidos. No caso dos hidrantes, são os números dos hidrantes. Em seguida, clique em OK.

Veja no project workspace o link criado.

Clicando o botão direito do mouse sobre o link você pode visualizar a tabela, editar a tabela além de gerar os links automaticamente e até mesmo apagar os links.

A edição e visualização é feita através do Data View.

Logo após cria o link path name, salve seu projeto. 
Uma vez que tenha vinculado e conectado a um banco de dados e tabelas e definido o LPN para cada tabela você já pode iniciar a linkagem dos objetos.

\section{Criar links manualmente}

Você pode vincular entidades a seu mapa usando a linkagem manual no Data View.

Siga os passos:

1. Clique duas vezes no Link path name no Project Workspace.

2. Selecione um registro, clicando no canto extremo esquerdo da linha.

3. No Data View, clique no menu Link

4. Selecione Link Records to Object

5. Selecione os objetos que deseja associar ao registro e em seguida, tecle ENTER.

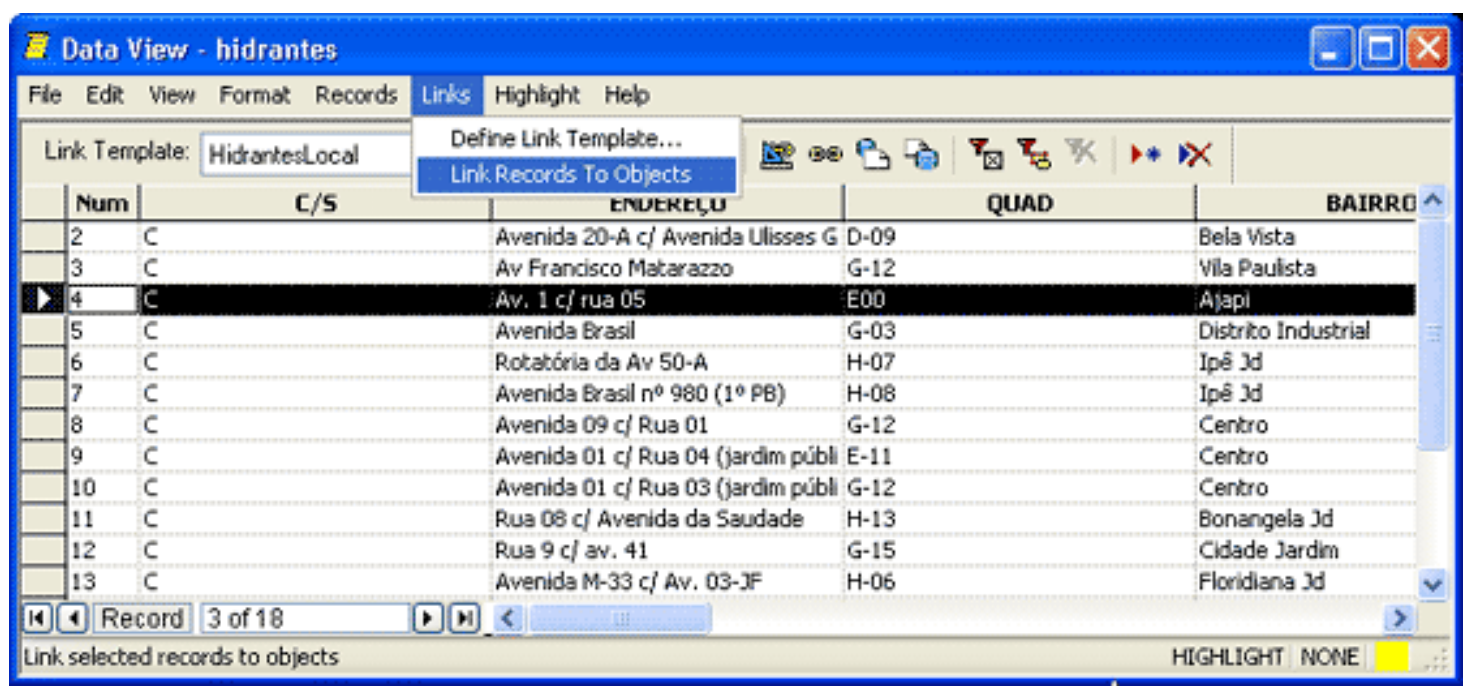

\section{Destacando e visualizando links}

Tendo linkado seus registros de banco de dados em seu mapa, você pode usar o Data View para destacar e visualizar as entidades ou registros correspondentes na tabela do banco de dados conectado a sua sessão de trabalho. 
Para destacar e aproximar uma entidade linkada a um registro.

1. Em Data View, selecione um ou mais registros.

2. No menu HighLight, escolha AutoZoom. Esta opção automaticamente aumenta as entidades selecionadas na escala que você especificar em Zoom Scale.

3. No menu highlight, escolha zoom scale. Na caixa de diálogo, entre com um valor e depois OK.

4. Se você digitar o valor 50 , significa que as entidades linkadas serão aumentadas de forma que preencham $50 \%$ do vídeo.

5. No menu Highlight, escolha Highlight Objects.

Para identificar e aproximar várias entidades em um ou mais registros:

1. No Dataview, clique no menu Highlight e escolha AutoZoom.

2. No menu HighLight, escolha zoom scale. Na caixa de diálogo, entre com um valor e depois OK.

3. No menu HighLight, escolha AutoHightLight.

4. Com o AutoHighLight, o Autocad Map automaticamente destaca todas as entidades no mapa que estão linkados em registros no Data View.

5. No Data View, selecione um ou mais registros.

6. Se você selecionou um registro, o Autocad Map destaca a entidade linkada e aproxima no percentual que você configurou anteriormente.

7. Quando concluir a seleção, pressione ENTER.

8. O DataView mostra os registros associados com as entidades que você relacionou.

\section{Para limpar os registros destacados}

No menu HighLight, escolha HighLight Record e depois Clear HighLight. 


\section{Destacando e visualisando registros linkado em entidades}

Tendo feita a linkagem de registros no mapa, você pode usar o Data View para verificar a linkagem.

1. Primeiro, especifique a cor para destacar em DataView.

2. No menu HightLight, escolha Color.

3. Na caixa de diálogo select color configure uma cor que ficará configurado até que você a troque.

4. No menu HighLight, escolha HighLight Records $\rightarrow$ Select Records.

5. No mapa, selecione uma ou mais entidades.

6. Pressione ENTER.

7. Surgem no DataView os registros correspondentes a entidades gráficas no mapa.

\section{Observação:}

Tanto o banco de dados externo como os links e as pesquisas devem ser criados dentro da sessão de trabalho. Esta sendo salva, permite ao abrir a sessão novamente que todas as tabelas, links e pesquisas sejam carregadas automaticamente.

\section{Criando filtros através do Data View}

O menu Records do Data View possui duas opções para fazer a filtragem de registros:

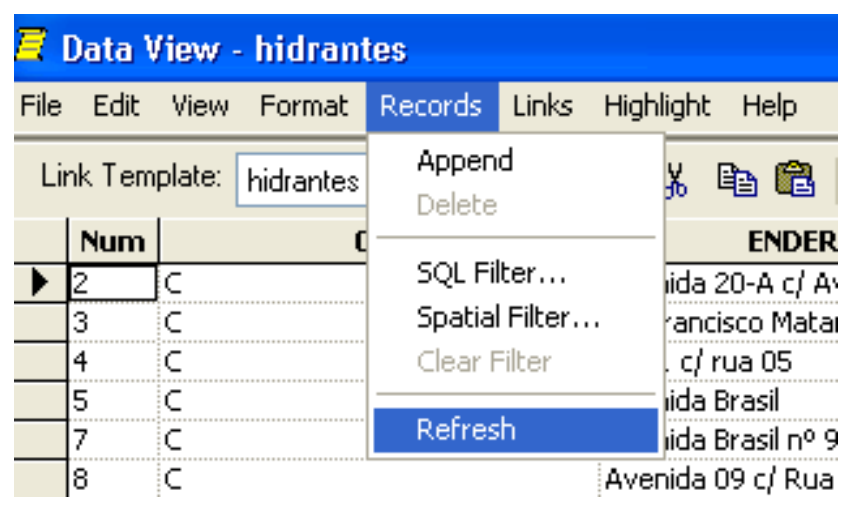


Spatial Filter: Selecionando esta opção é possível selecionar os objetos no mapa. Ao teclar o Enter, o Data view mostra apenas os registros associados aos objetos selecionados.

SQL Filter: Usando a opção SQL Filter, surge um quadro onde você deve informar o campo (coluna) pelo qual vai pesquisar, o operador (igual, maior, menor, etc.) e o valor (value). Em seguida clique no botão ADD e depois em OK. É possível combinar vários critérios para o filtro usando a opção AND e OR.

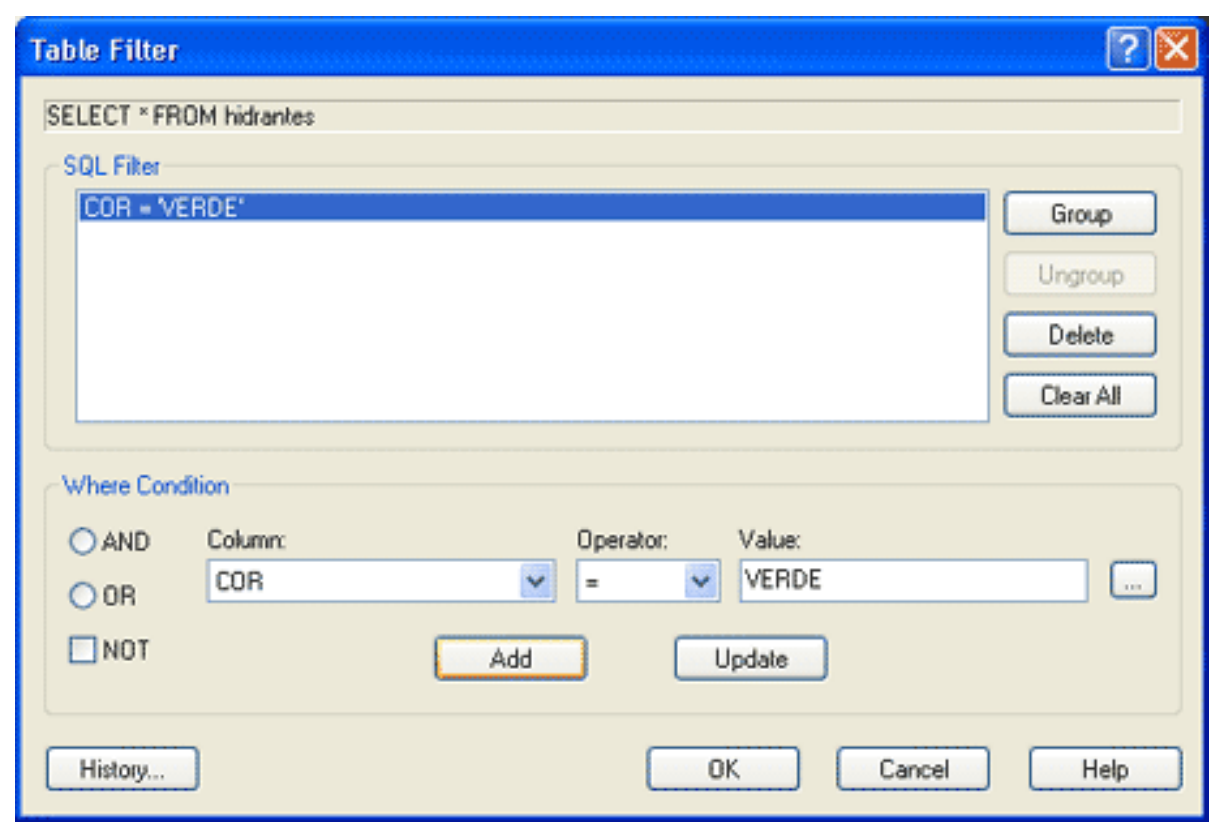

O opção Clear Filter do menu Records permite remover o filtro aplicado aos registros.

A opção Append permite ao usuário inserir um novo registro na tabela.

A opção Delete permite excluir um registro da tabela.

Observação:

Ao excluir um registro, o objeto associado a ele não é excluído do mapa. 


\section{Pesquisando em banco de dados externo}

É possível realizar pesquisas diretamente no banco de dados associado ao mapa através da consulta em SQL.

No Menu Map, escolha Query e depois Define Query.

No quadro, escolha o botão SQL.

Surge o seguinte quadro:

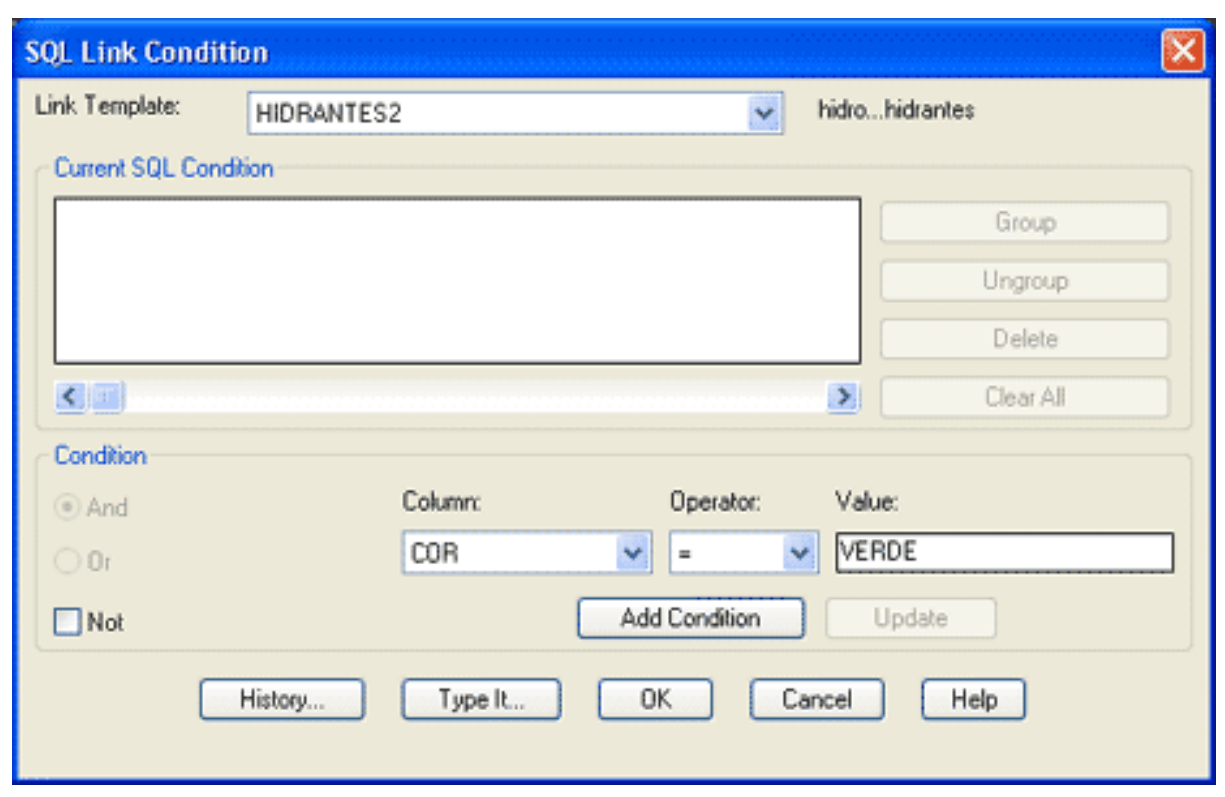

Escolha o Link Template criado. Na área condition, escolha a coluna que será pesquisada, o operador (igual, maior, menor) e o valor que deseja pesquisar. Em seguida, clique no botão Add condition e depois em OK.

\section{Considerações sobre consultas}

As consultas devem ser criadas na sessão de trabalho, principalmente as que utilizam critérios em SQL.

É possível criar uma lista de consultas previamente salvas para que sejam executadas quando necessário.

Para utilizar consultas do tipo SQL é interessante criar uma sessão de trabalho somente para trabalhar este tipo de consulta no mapa. Neste caso pode-se 
criar uma consulta que retorne todos os layers de quadras e identificação de ruas. Esta consulta pode ser executada no modo Draw para que seja salva na sessão de trabalho e para que fique "ativa" toda vez que esta sessão for aberta. Os layer dos hidrantes ficam ocultos neste mapa.

Em seguida, pode-se criar as consultas, por exemplo, criar uma consulta que retorne todos os hidrantes verdes em um raio de 1000 metros. Ao criar esta consulta, o usuário em seguida deve dar OK e salvar a sessão sem executar a consulta.

Fecha então a sessão e abra-a novamente. Em seguida o usuário pode executá-la no modo Preview, pois desta forma o Autocad não desenhará a consulta no mapa. Ao fechar a sessão não se deve salvar o arquivo.

Assim, ao abrir a sessão novamente esta consulta não estará gravada no mapa e será possível edita-la, ou seja, consultar hidrantes que estão em um raio de 1000 metros em outra região do mapa.

A consulta que mostra apenas as quadras deve ser executada no modo Draw e em seguida salva na sessão de trabalho para que ao abrir a sessão todas as quadras sejam apresentadas. 
Apêndice B - Cronograma das aulas de Autocad Map

Consultas ao mapa 
Visualizando informações com o Data View:

Após ter vinculado o banco de dados no seu mapa, você pode usar a ferramenta DataView para visualizar os seus dados. Para isso, basta clicar duas vezes sobre a tabela desejada no project workspace.

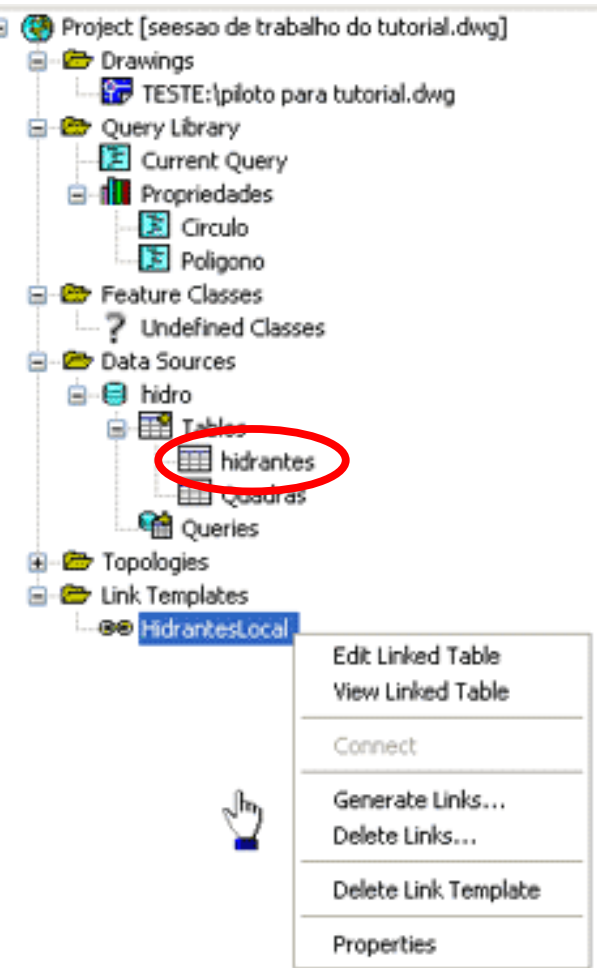

Ao clicar duas vezes sobre o link da tabela, surge o Data View com os registros cadastrados.

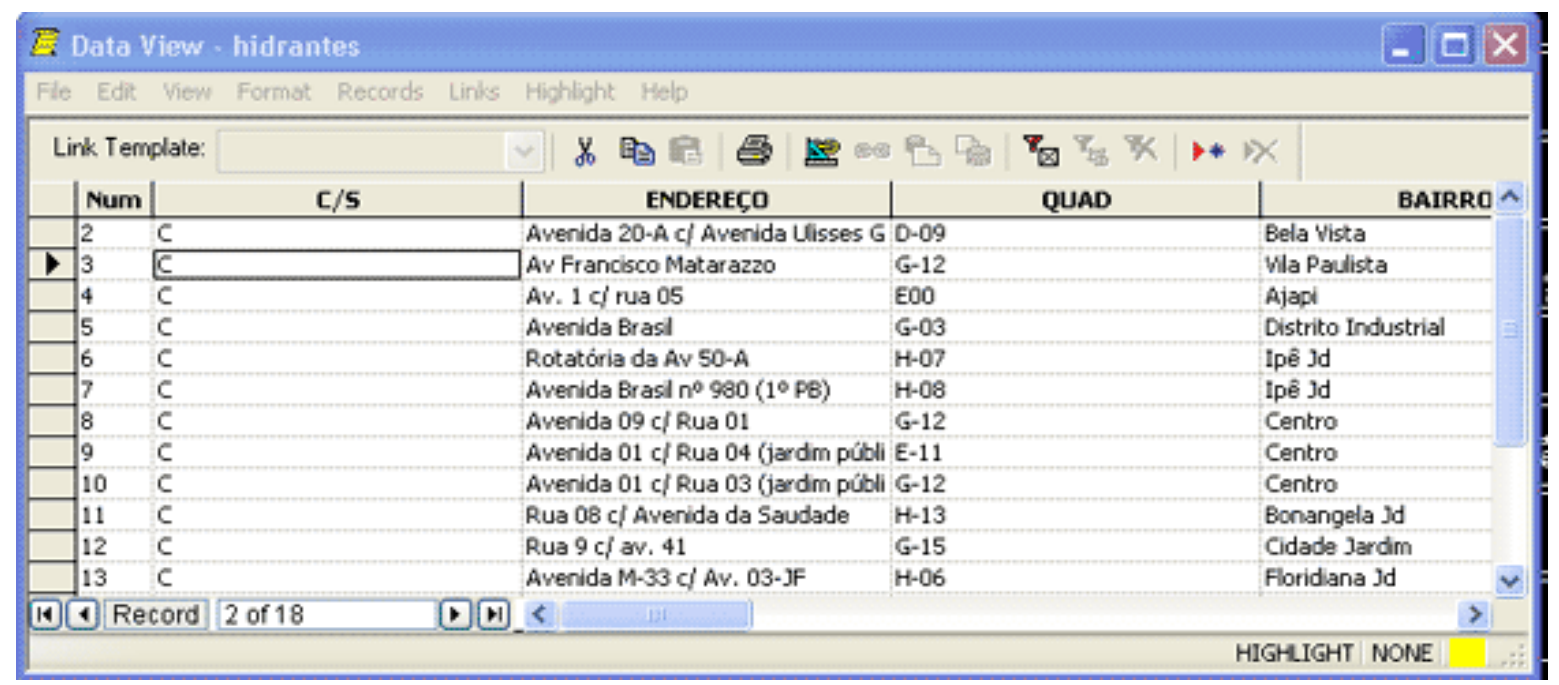

\section{Destacando e visualizando links}

Tendo linkado seus registros de banco de dados em seu mapa, você pode usar o Data View para destacar e visualizar as entidades ou registros correspondentes na tabela do banco de dados conectado a sua sessão de trabalho. 


\section{Para destacar e aproximar uma entidade linkada a um registro.}

6. Em Data View, selecione um ou mais registros.

7. No menu HighLight, escolha AutoZoom. Esta opção automaticamente aumenta as entidades selecionadas na escala que você especificar na opção Zoom Scale que fica no mesmo menu.

8. No menu highlight, escolha zoom scale. Na caixa de diálogo, entre com um valor e depois OK.

9. Se você digitar o valor 50 , significa que as entidades linkadas serão aumentadas de forma que preencham $50 \%$ do vídeo.

10. Clique no seletor de registro na tabela de hidrantes. Ele é um "quadradinho" que fica ao lado do numero do hidrante. Veja a figura:

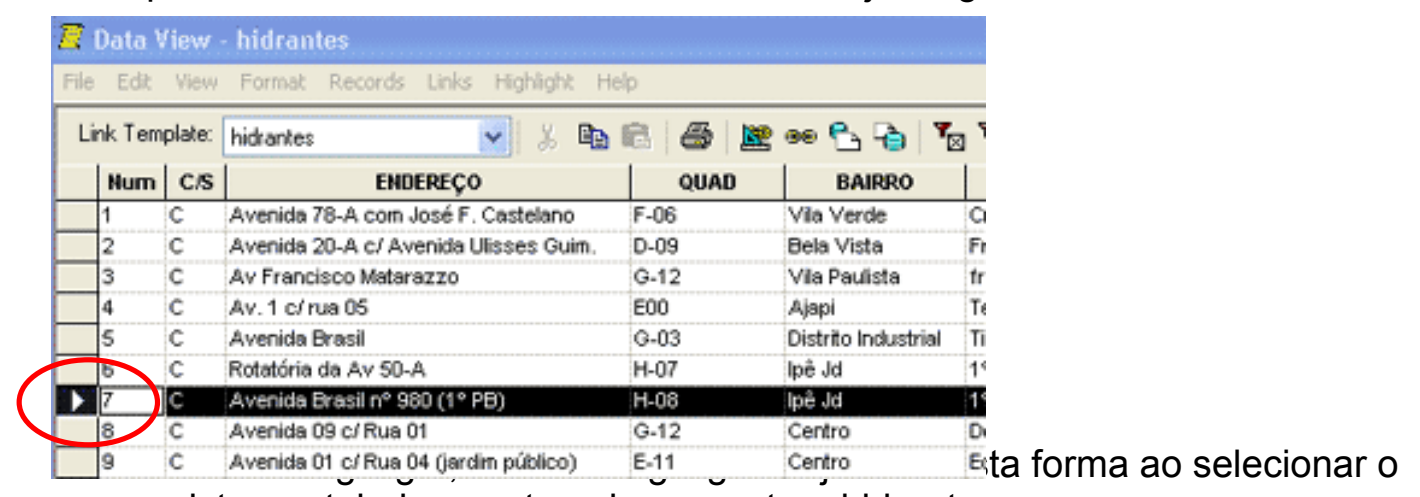
registro na tabela o autocad apresenta o hidrante no mapa.

12. Se preferir ligue a opção Auto Select deste menu para que a seleção seja feita automaticamente

\section{Para identificar e aproximar várias entidades em um ou mais registros:}

9. No Dataview, clique no menu Highlight e escolha AutoZoom.

10. No menu HighLight, escolha zoom scale. Na caixa de diálogo, entre com um valor e depois OK.

11. No menu HighLight, escolha AutoHightLight.

12. Com o AutoHighLight, o Autocad Map automaticamente destaca todas as entidades no mapa que estão linkados em registros no Data View.

13. No Data View, selecione um ou mais registros.

14. Se você selecionou um registro, o Autocad Map destaca a entidade linkada e aproxima no percentual que você configurou anteriormente.

15. O DataView mostra os registros associados com as entidades que você relacionou.

Observação: é interessante você deixar marcadas as opções AutoZoom, AutoHighlight, e AutoSelect do menu Highlight. Desta forma, ao selecionar um registro, o Autocad já destaca-o, seleciona-o e aproxima-o na tela.

\section{Para limpar os registros destacados}

No menu HighLight, escolha HighLight Record e depois Clear HighLight. 


\section{Destacando e visualizando registros linkados em entidades}

Tendo feita a linkagem de registros no mapa, você pode usar o Data View para verificar a linkagem.

8. Primeiro, especifique a cor para destacar em DataView.

9. No menu HightLight, escolha Color.

10. Na caixa de diálogo select color configure uma cor que ficará configurado até que você a troque.

11. No menu HighLight, escolha HighLight Records $\rightarrow$ Select Records.

12. No mapa, selecione uma ou mais entidades.

13. Pressione ENTER.

14. Surgem no DataView os registros correspondentes a entidades gráficas no mapa.

\section{Ajustando a cor de seleção dos objetos no mapa.}

Ao selecionar um objeto no mapa, o Autocad destaca-o com um ponto na cor azul. Esta é a cor padrão, mas você pode alterar esta cor. Pode também alterar o tamanho do ponto de seleção para que fique mais fácil encontrá-lo no mapa. Este ponto o Autocad chama de grips. Veja como altera-lo:

1. No menu Tools, escolha Options

2. No quadro, selecione a guia Selection.

3. Para aumentar o tamanho do ponto de seleção, aumente-o na opção Grip Size.

4. Para mudar a cor do ponto altere-a na caixa Unslected Grip Color. Em seguida clique no botão OK. Veja o quadro abaixo:

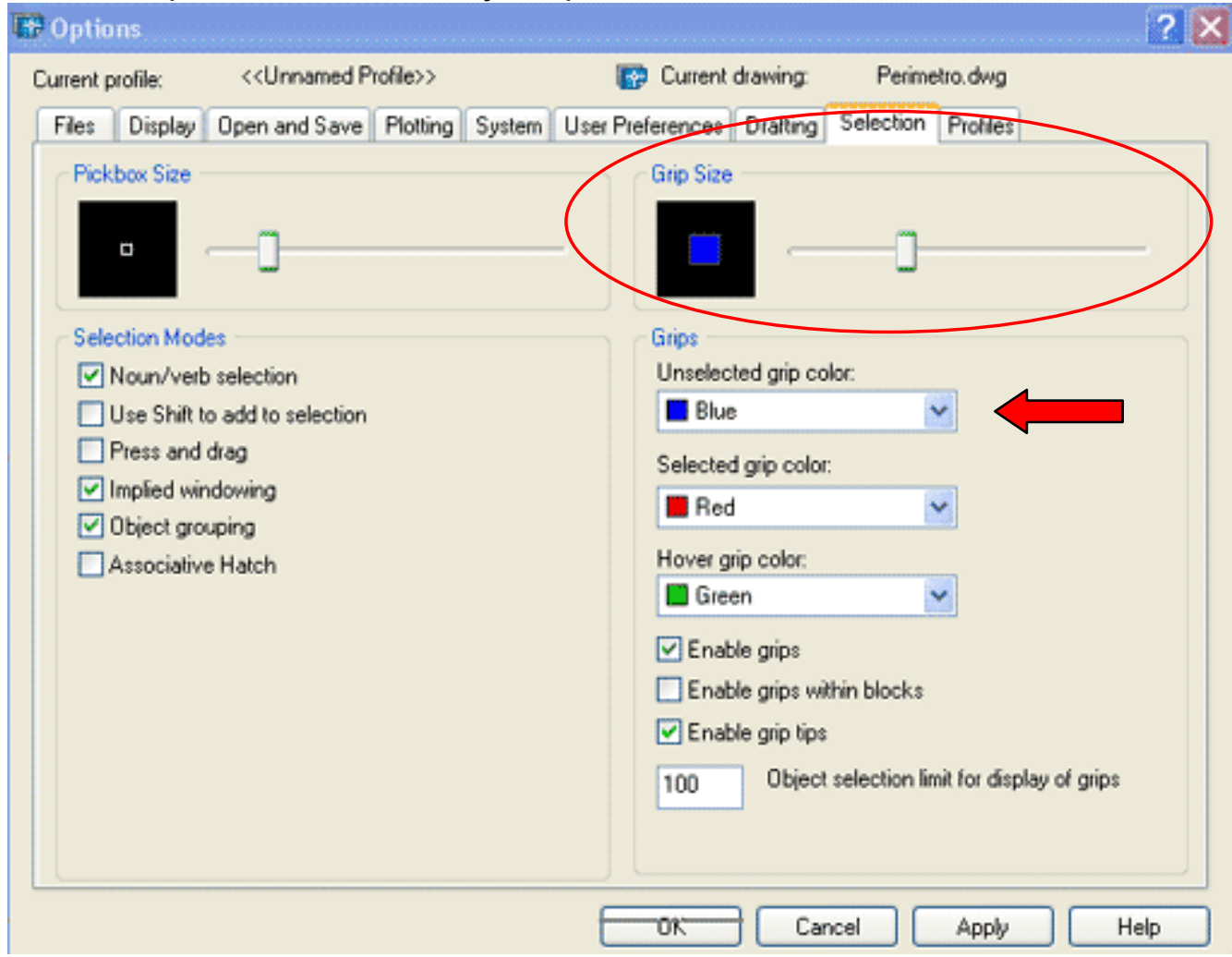

Observação:

Tanto o banco de dados externo como os links e as pesquisas devem ser criados dentro da sessão de trabalho. Esta sendo salva, permite ao abrir a sessão novamente que todas as tabelas, links e pesquisas sejam carregadas automaticamente. 


\section{Criando filtros através do Data View}

O menu Records do Data View possui duas opções para fazer a filtragem de registros:

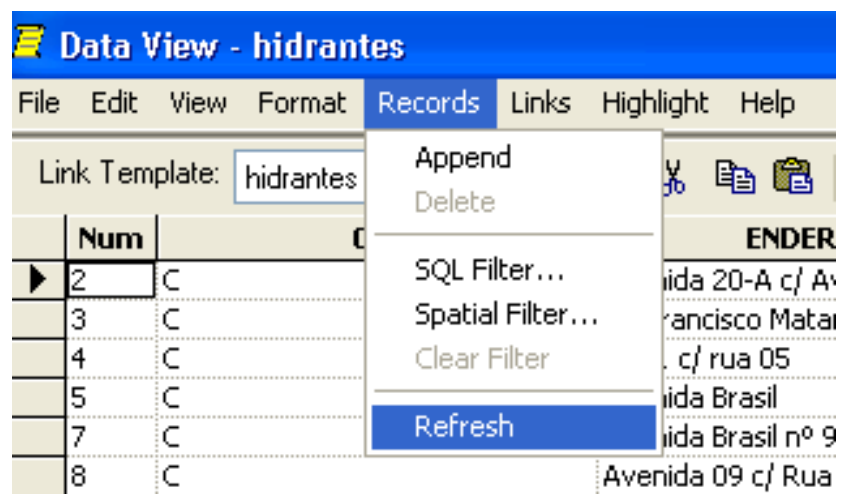

Spatial Filter: Selecionando esta opção é possível selecionar os objetos no mapa. Ao teclar o Enter, o Data view mostra apenas os registros associados aos objetos selecionados.

SQL Filter: Usando a opção SQL Filter, surge um quadro onde você deve informar o campo (coluna) pelo qual vai pesquisar, o operador (igual, maior, menor, etc.) e o valor (value). Em seguida clique no botão ADD e depois em OK. É possível combinar vários critérios para o filtro usando a opção AND e OR.

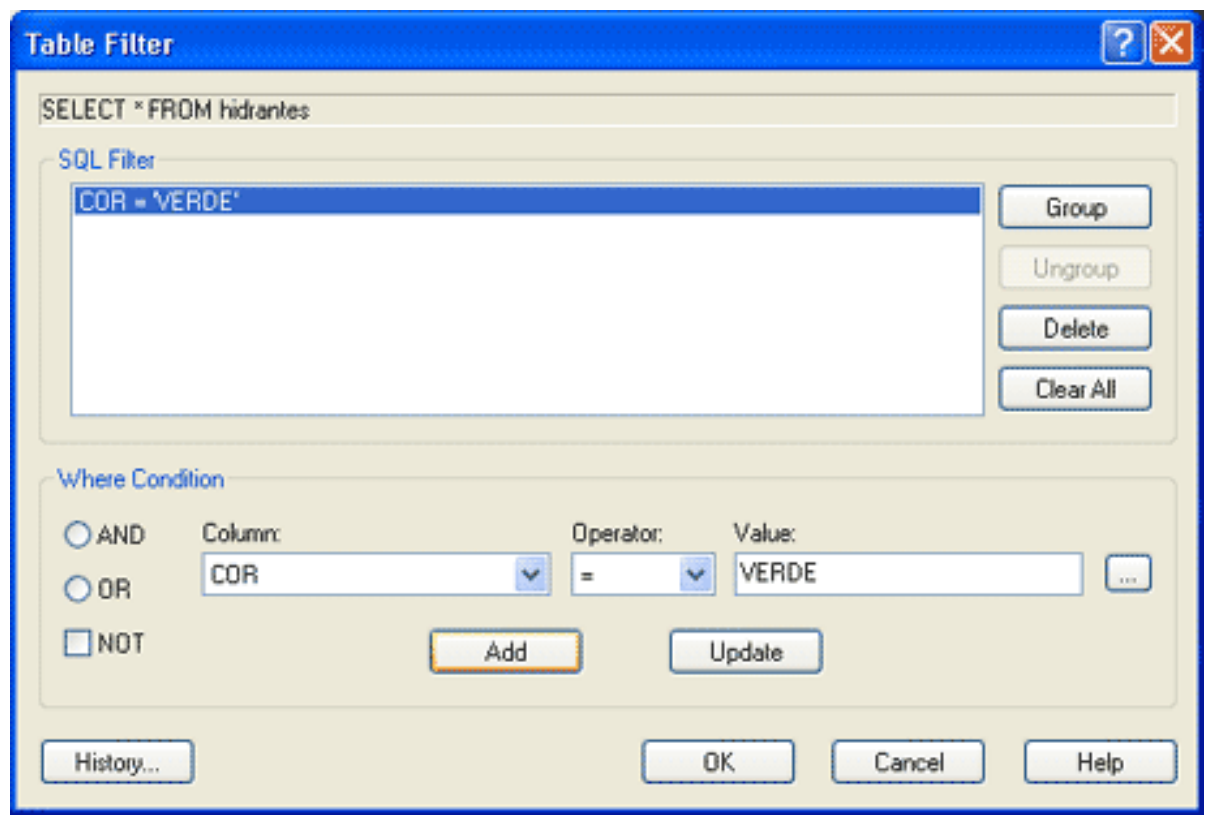

O opção Clear Filter do menu Records permite remover o filtro aplicado aos registros.

A opção Append permite ao usuário inserir um novo registro na tabela.

A opção Delete permite excluir um registro da tabela.

Observação:

Ao excluir um registro, o objeto associado a ele não é excluído do mapa. 


\section{Usando a barra de botões para agilizar seu trabalho}

O Autocad Map possui uma grande quantidade de botões. Foi criada para você uma barra de botões personalizada com alguns dos comandos mais comuns que irá utilizar no seu dia-a-dia.

Veja uma explicação destes botões logo abaixo:

\begin{tabular}{|c|c|c|}
\hline 级 & OPEN & Usado para abrir um arquivo do Autocad. \\
\hline 目 & SAVE & Usado para salvar as alterações feitas no mapa \\
\hline$f$ & UNDO & Desfaz uma alteração que você fez por engano. \\
\hline 7 & REDO & Refaz uma alteração desfeita pelo comando UNDO \\
\hline$Q^{ \pm}$ & ZOOM REALTIME & $\begin{array}{l}\text { Aproxima ou distancia elementos na tela. Clique neste } \\
\text { botão. Em seguida, ao levar o cursor para o mapa, clique e } \\
\text { arraste para cima para aproximar e para baixo para } \\
\text { distanciar. }\end{array}$ \\
\hline Q & ZOOM PREVIOUS & Volta a visualização anterior. \\
\hline QR & ZOOM WINDOWS & $\begin{array}{l}\text { Aproxima uma área do mapa. Clique em um ponto do mapa } \\
\text { e em seguida abra uma janela envolvendo a parte que } \\
\text { deseja aproximar (não mantenha o botão pressionado). } \\
\text { Depois, clique novamente. }\end{array}$ \\
\hline 잿 & ZOOM CENTER & $\begin{array}{l}\text { Este comando, solicita um ponto central para a } \\
\text { aproximação e também um fator de aproximação. Quanto } \\
\text { menor o valor informado, mais próximo o ponto será } \\
\text { ampliado. }\end{array}$ \\
\hline Ф & ZOOM IN & Aproxima o desenho \\
\hline$Q$ & ZOOM OUT & Distancia o desenho \\
\hline (4) & ZOOM ALL & Mostra todo o mapa na tela \\
\hline 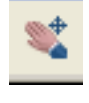 & PAN & $\begin{array}{l}\text { Usado para deslocar o mapa na tela. Clique e arraste para } \\
\text { deslocar o mapa. }\end{array}$ \\
\hline ....... & DIST & $\begin{array}{l}\text { Usando para medir uma distancia entre dois pontos. Para } \\
\text { usar este comando, clique no ponto inicial e depois clique } \\
\text { no ponto final. Veja no prompt de comando a distancia } \\
\text { medida e também outras informações. }\end{array}$ \\
\hline 綮 & PROPERTIES & $\begin{array}{l}\text { Usado para apresentar as propriedades de um objeto. Este } \\
\text { quadro permite realizar alterações nos objetos. }\end{array}$ \\
\hline
\end{tabular}




\section{Trabalhando com as camadas}

Todo o mapa está dividido em camadas. Cada camada representa uma coleção de objetos no mapa como por exemplo, hidrantes, identificação das ruas, baiross, cercas, estradas, jardins, pontos de referência e etc.

Cada camada dessa pode ser trabalhada em separado. Por exemplo, se você não gostou da cor da identificação dos bairros você pode alterar para outra cor que acha mais conveniente.

Se desejar, pode também esconder algumas camadas para que fique melhor a visualização de informações no mapa. Veja um exemplo da lista de camadas no mapa:

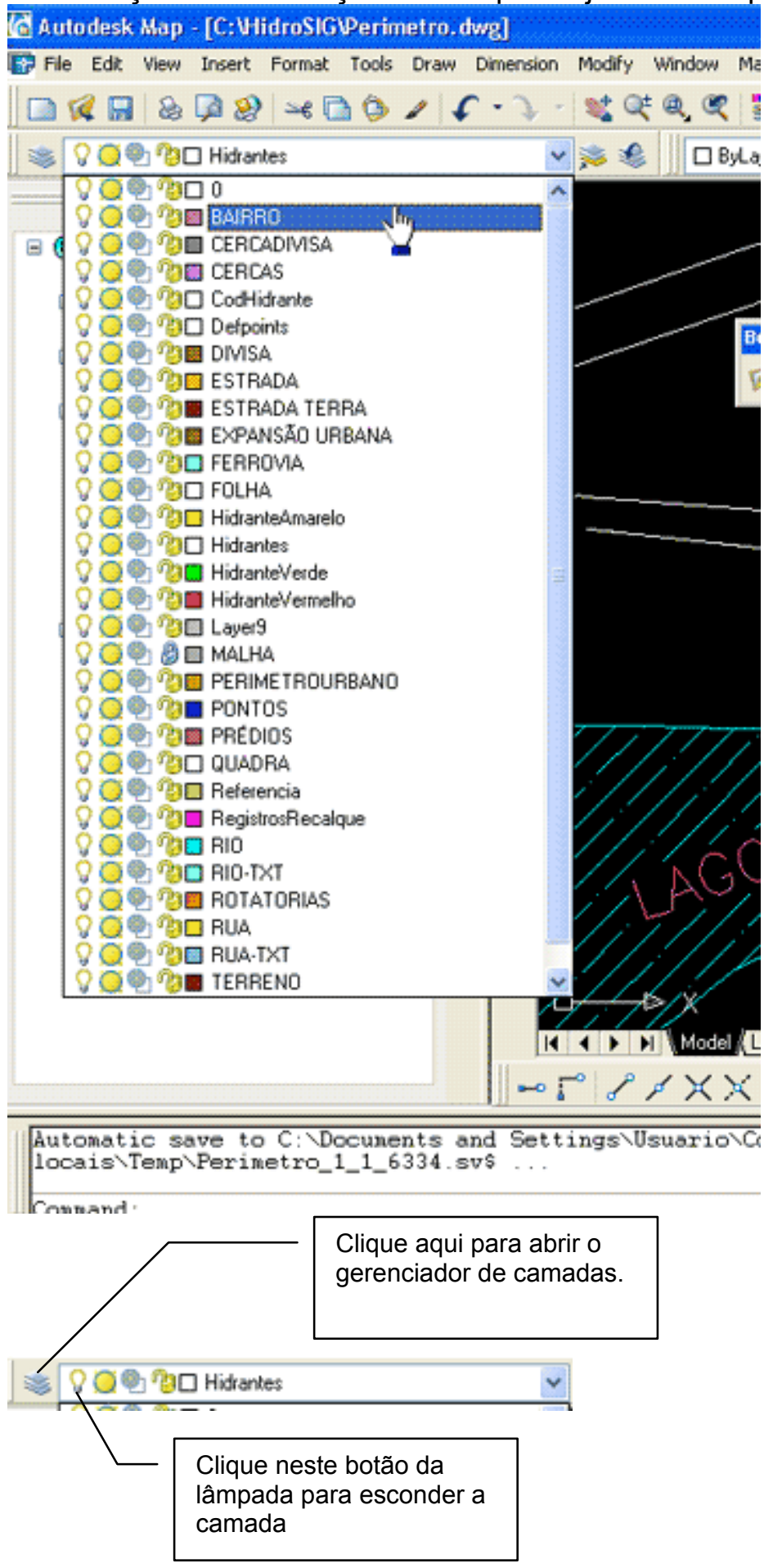




\section{O gerenciador de camadas}

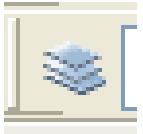

Ao clicar no botão gerenciador de camadas (layers) a seguinte tela á apresentada:

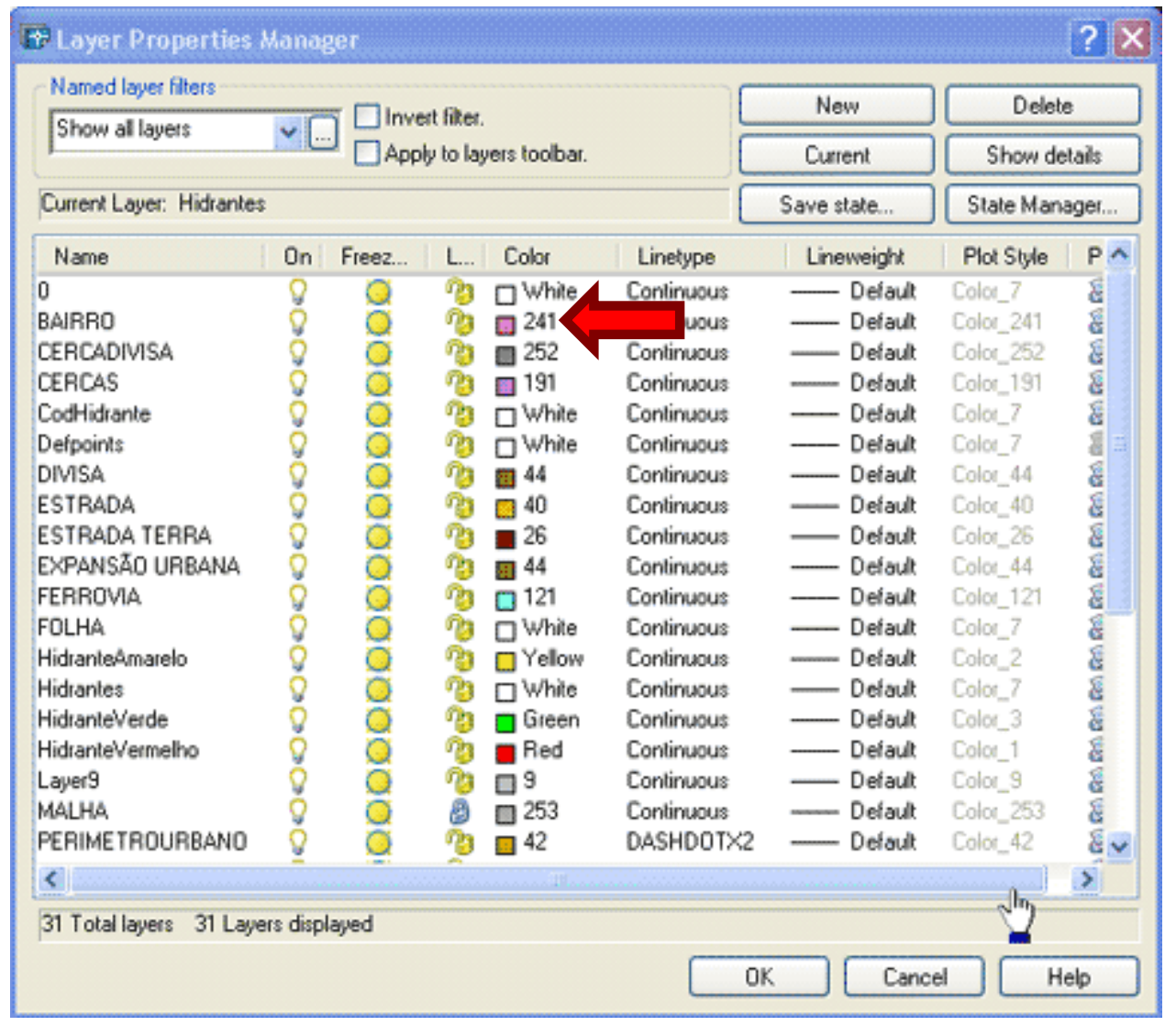

Para mudar a cor de uma camada, clique no item cor. (veja a seta indicando no quadro) Em seguida surgirá um novo quadro. Nele, escolha uma cor e confirme no OK. 
Apêndice C - Diário de Pesquisa 
O diário de pesquisa foi criado após as primeiras visitas ao Posto de Bombeiros. Não foram relatados aqui os encontros realizados para determinar as necessidades e objetivos do sistema. Este diário foi criado nos primeiros encontros realizados dentro do NAT para obtenção de informações para criação do sistema. Os nomes aqui relatados foram abreviados para preservar a privacidade dos bombeiros

\begin{tabular}{|c|c|}
\hline Data & \\
\hline $30 / 01 / 05$ & $\begin{array}{l}\text { Visita ao Posto de Bombeiros para conhecer o funcionamento do } \\
\text { NAT e colher as primeiras informações sobre os pontos de } \\
\text { abastecimento com o bombeiro } N \text {. }\end{array}$ \\
\hline $15 / 02 / 05$ & $\begin{array}{l}\text { Visita ao Posto de Bombeiros para colher informações sobre os } \\
\text { registros de recalque e hidrantes com o bombeiro } \boldsymbol{N} \text {. }\end{array}$ \\
\hline $21 / 02 / 05$ & $\begin{array}{l}\text { Instalado o sistema operacional Windows XP no computador do } \\
\text { NAT. Foi feita uma visita para orientar o pessoal deste departamento } \\
\text { no uso desta nova versão do sistema operacional. }\end{array}$ \\
\hline 01/03/05 & $\begin{array}{l}\text { Visita para instalar o software do Autocad Map. Foi aproveitado o } \\
\text { tempo para tirar dúvidas e fazer backup dos dados para o bombeiro } \\
\text { N.. }\end{array}$ \\
\hline 04/03/05 & $\begin{array}{l}\text { Iniciada a primeira etapa do treinamento com o bombeiro } \boldsymbol{N} \text {.. Neste } \\
\text { dia o treinamento incluiu a apresentação do Autocad Map e alguns } \\
\text { comandos básicos do sistema como: line, erase, save, coordenadas, } \\
\text { dist, grid, snap, limits, circle, arc }\end{array}$ \\
\hline $14 / 03 / 05$ & $\begin{array}{l}\text { Treinamento com o bombeiro } \mathbf{N} \text { : revisão do exercício que foi } \\
\text { deixado no último encontro. Inicio das camadas com o comando } \\
\text { layer. }\end{array}$ \\
\hline 22/03/05 & $\begin{array}{l}\text { Terceira aula da primeira etapa do treinamento com o bombeiro } \mathbf{N} . \text {. } \\
\text { Comandos para alteração do mapa: offset, fillet, extend, linetyoe, } \\
\text { trim, modify properties. }\end{array}$ \\
\hline 29/03/05 & $\begin{array}{l}\text { Quarta aula da primeira etapa do treinamento com o bombeiro } N \text {.. } \\
\text { Comandos de precisão no desenho: Object snap, snap from, revisão } \\
\text { dos comandos já vistos. }\end{array}$ \\
\hline
\end{tabular}




\begin{tabular}{|c|c|}
\hline 26/04/05 & $\begin{array}{l}\text { Quinta aula da primeira etapa com o bombeiro } N \text {.. Inicio de um } \\
\text { exercício com mapa. Entregue uma apostila de comandos já vistos } \\
\text { em aula. }\end{array}$ \\
\hline 03/05/05 & $\begin{array}{l}\text { exta aula com o bombeiro } \boldsymbol{N} \text {.. Termino do exercício no mapa. Foi } \\
\text { prendido com se inclui texto no mapa através do comando dtext e } \\
\text { ext style }\end{array}$ \\
\hline 17/05/05 & $\begin{array}{l}\text { sita para acompanhar o uso do Autocad e das ferramentas } \\
\text { rendidas durante o treinamento. }\end{array}$ \\
\hline 30/05/05 & $\begin{array}{l}\text { Sétima aula com o bombeiro } \boldsymbol{N} \text {.. Encerramento da primeira etapa do } \\
\text { treinamento. Foram aprendidos os comandos para inserção de } \\
\text { blocos: wblock e insert. Criado o bloco dos hidrantes. }\end{array}$ \\
\hline 28/06/05 & $\begin{array}{l}\text { Início da segunda etapa do treinamento. Participaram no primeiro } \\
\text { encontro: bombeiros } \boldsymbol{N} \text {. e } \boldsymbol{S} \text {.. Foi passado como se faz a inclusão do } \\
\text { hidrante no banco de dados e como é criado o link com o mapa. Foi } \\
\text { visto também como é feita a consulta em dos pontos de } \\
\text { abastecimento no mapa. O pessoal teve algumas dificuldades em } \\
\text { aprender. } \\
\text { No período da tarde, participou do treinamento o bombeiro } T \text {.. Neste } \\
\text { treinamento foi passada apenas a parte da consulta. O resultado foi } \\
\text { melhor. O bombeiro assimilou mais apenas estes procedimentos. }\end{array}$ \\
\hline 05/07 & $\begin{array}{l}\text { egunda etapa do treinamento. Participou o bombeiro } \boldsymbol{D} \text {.. Foi } \\
\text { mplificada a aula de consultas no mapa. O bombeiro assimilou } \\
\text { em esta parte. }\end{array}$ \\
\hline $12 / 07 / 05$ & $\begin{array}{l}\text { egunda etapa do treinamento. Participou o bombeiro } F . . \text { Foi } \\
\text { assada apenas a parte de consultas no mapa. O bombeiro tem } \\
\text { cilidade em aprender. }\end{array}$ \\
\hline $19 / 07 / 05$ & $\begin{array}{l}\text { Visita ao posto e relatada as dificuldades em encontrar os registros } \\
\text { de recalque no mapa. O bombeiro do NAT ajudou na localização de } \\
\text { alguns pontos. }\end{array}$ \\
\hline 26/07/05 & $\begin{array}{l}\text { Reunião com o bombeiro C.. Foram discutidos alguns problemas } \\
\text { com relação à localização dos registros de recalque e à duplicidade } \\
\text { de informações no sistema SICAT. } \\
\text { Foi conversado sobre a possibilidade de incluir uma camada com as }\end{array}$ \\
\hline
\end{tabular}




\begin{tabular}{|c|c|}
\hline & áreas de risco no município. Por exemplo: depósitos de gás, \\
\hline 09/08/05 & Visita ao posto para corrigir e atualizar os hidrantes no mapa. \\
\hline 11/08/05 & $\begin{array}{l}\text { Revisados os registros de recalque no mapa. Foi feita uma filtragem } \\
\text { dos registros e foram selecionados } 44 \text { registros de recalque para } \\
\text { colocar no mapa. Os que não foram encontrados foram separados } \\
\text { para que o bombeiro no NAT possa verificar sua localização. }\end{array}$ \\
\hline 16/08/05 & $\begin{array}{l}\text { Visita ao posto de bombeiros. Relatados alguns problemas na } \\
\text { localização de alguns registros de recalque. } \\
\text { Passada a terceira etapa do treinamento para o bombeiro } \mathbf{N} .\end{array}$ \\
\hline 30/08/05 & $\begin{array}{l}\text { Visita ao posto para acertar detalhes da instalação de um novo } \\
\text { computador para o telefonista }\end{array}$ \\
\hline 09/09/05 & $\begin{array}{l}\text { Visita ao posto. Foi deixada uma lista de registros de recalque com o } \\
\text { bombeiro } \boldsymbol{N} \text {. para verificar a localização no mapa. }\end{array}$ \\
\hline 12/09/05 & $\begin{array}{l}\text { Instalado o computador no atendimento. Foi solicitada a criação de } \\
\text { um novo banco de dados para a consulta a telefones já que o antigo } \\
\text { estava tendo problemas em funcionar com o novo sistema } \\
\text { operacional Windows XP. Este banco de dados não tem relação } \\
\text { com o projeto de pesquisa. }\end{array}$ \\
\hline 14/09/05 & $\begin{array}{l}\text { Instalado no atendimento o sistema para localização de telefones. } \\
\text { Foram agendados novos dias para o treinamento do pessoal. }\end{array}$ \\
\hline 27/09/05 & $\begin{array}{l}\text { Quarta etapa do treinamento com o sistema final já instalado no } \\
\text { atendimento. Participou do treinamento o bombeiro } S \text {.. Foi revisada } \\
\text { a parte consultas ao mapa. O bombeiro não teve dificuldades em } \\
\text { assimilar os procedimentos }\end{array}$ \\
\hline 28/09/05 & $\begin{array}{l}\text { Quarta etapa do treinamento. Participou do treinamento o bombeiro } \\
\text { F.. Foi revisada a parte consultas ao mapa. O bombeiro não teve } \\
\text { dificuldades em assimilar os procedimentos }\end{array}$ \\
\hline
\end{tabular}

